\title{
31. LITHOLOGY OF SEDIMENTS FROM THE WESTERN NORTH ATLANTIC LEG 11 DEEP SEA DRILLING PROJECT
}

\author{
Yves Lancelot ${ }^{1}$, Laboratoire de Géologie Dynamique, Université de Paris-VI, \\ J. C. Hathaway, U.S. Geological Survey, Woods Hole, Massachusetts, and \\ C. D. Hollister ${ }^{2}$, Woods Hole Oceanographic Institution, Woods Hole, Massachusetts
}

\section{INTRODUCTION}

During Leg 11 of the Deep Sea Drilling Project, a wide range of sediments was found. They show diversity in composition and sedimentary structures. Basement rocks were penetrated at two sites, and, except for a short section near the base of the Tertiary, nearly all the units that presumably make up the sedimentary column in the North American basin were sampled.

The sediments are limestones, chalks, carbonate sands and silts, pure carbonate oozes, silica-rich carbonate ooze, hemipelagic mud with either a dominantly carbonate or siliceous biogenic fraction, somewhat zeolitic terrigenous deep-sea clays, volcanic clays containing abundant zeolites, diagenetic minerals, and terrigenous sands.

The sedimentary structures reflect environments of deposition ranging from very quiet conditions in which purely pelagic sediments were deposited, to turbidity flow conditions in which massive terrigenous deposits accumulated as turbidites. Features such as slumps, pelagic turbidites, flow structures and current bedding, fine horizontal laminations, and burrows were found that represent various conditions between these extremes. Some of the sites that were drilled are separated by hundreds of miles and extend from the Cat Gap area in the south to the latitude of Cape Hatteras in the north, yet the same structural and compositional facies were sampled at most of the sites. Correlations can also be made between the sites of Leg 11 and sites drilled during Legs 1 and 2; correlations can even be made with some of the sites drilled in the eastern Atlantic basin during Leg 14.

Separate consideration is given elsewhere to Site 98 (Paulus, in this volume), drilled in the Northwest Providence channel, as it is the only site out of the basin. Sites $99,100,101$, and 105 all yielded sediments as old as late Jurassic (see Figures 1 and 2). The Tertiary sediments of the Blake-Bahama Outer Ridge

\footnotetext{
${ }^{1}$ The author gratefully acknowledges financial support for this work provided by CNEXO (Centre National pour l'Exploitation des Oceans, France) under contracts 69/62, 69/117, $70 / 150$ and $71 / 253$.

${ }^{2}$ Woods Hole Oceanographic Institution Contribution No. 2730 .
}

(Sites 102, 103, 104) are similar to those found in Sites 105,106 and 107, and correlate well with those of Sites 6, 7 and 8 (Legs 1 and 2). Finally, some of the Jurassic sediments described here are very similar to rocks of the same age cropping out on land in the Mediterranean region (see chapter by D. Bernoulli in this volume). Comparisons of these separate occurrences provide a view of the sedimentary layers over a wide area and allow a better definition and understanding of the sedimentary processes.

Below we describe the sediments, facies by facies, beginning with the oldest rocks, and discuss possible environments of deposition to attempt a description of the evolution of the North American basin since the Late Jurassic.

\section{THE BASEMENT}

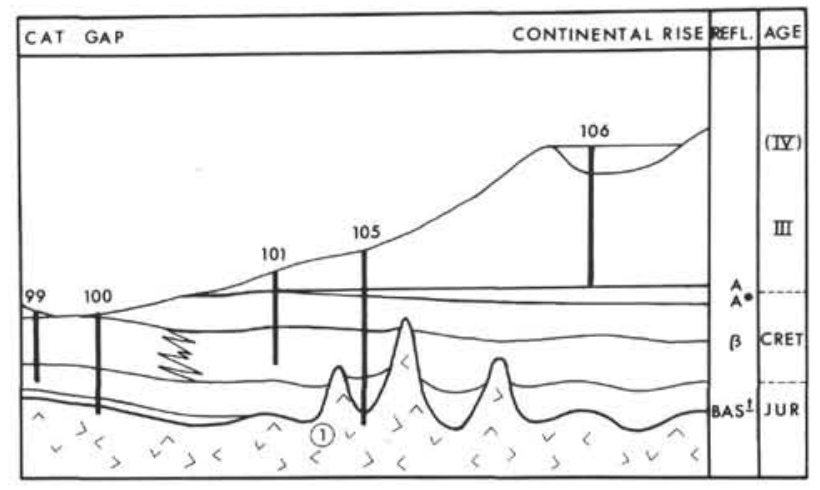

Basaltic rocks were recovered at Sites 100 and 105 and at both sites they undoubtedly represent the top part of the material identified as basement on the seismic profiles (see Site Reports).

Site 100 is inside the magnetically quiet zone, and Site 105 is near the boundary between the rough and quiet zones. 


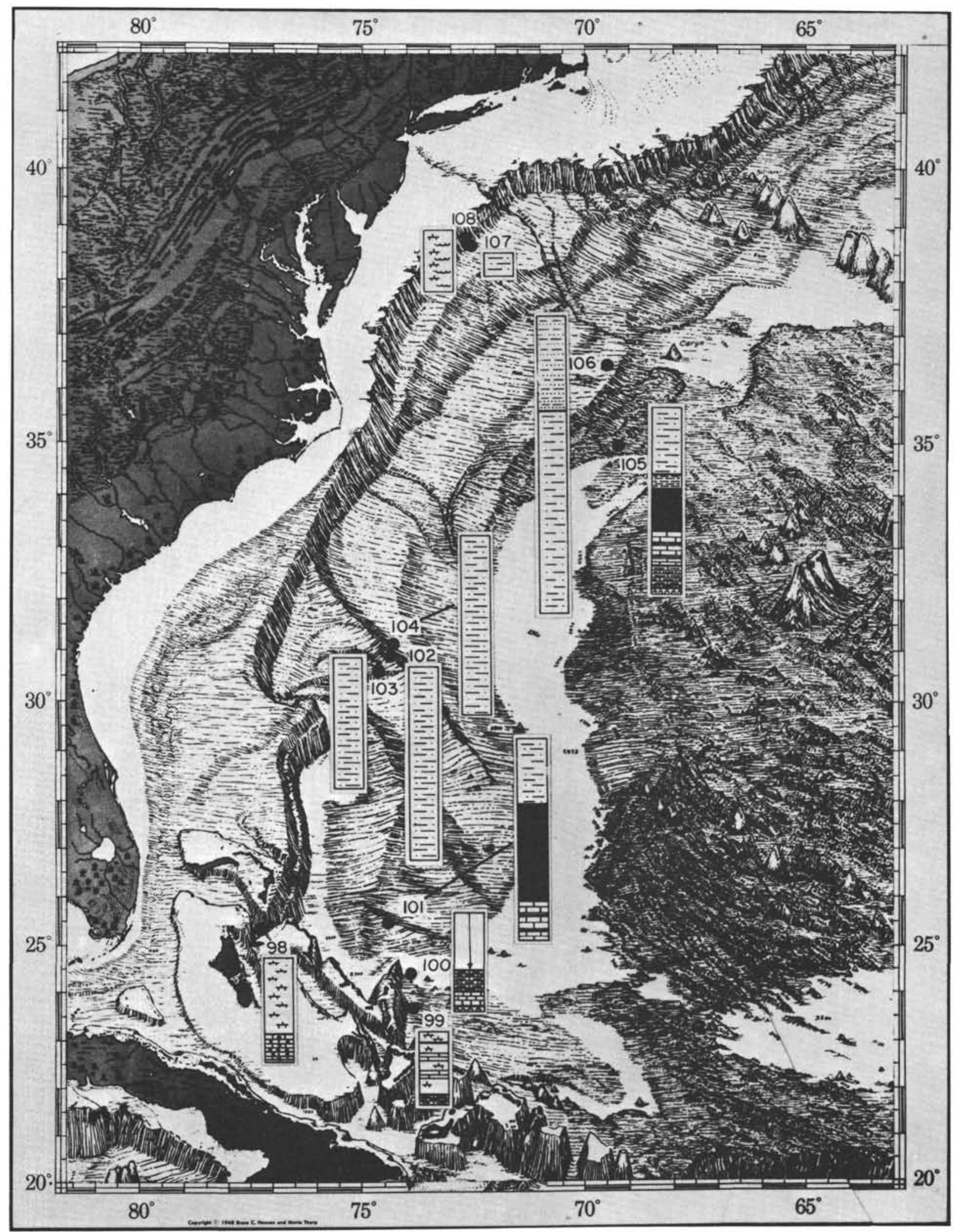

Figure 1. Leg 11 sites and lithologic summaries (Physiographic map by B. C. Heezen and M. Tharp, 1968). 


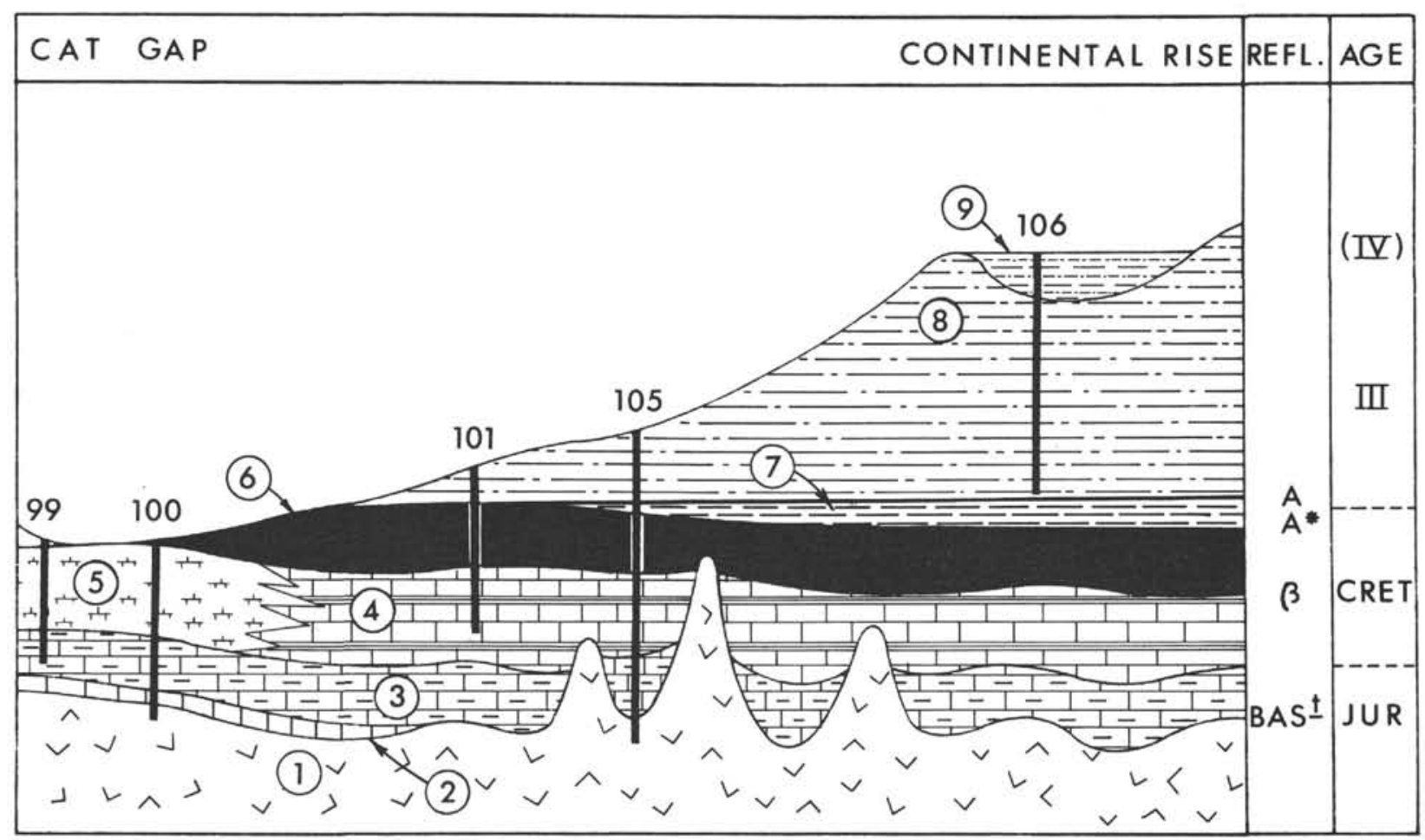

1. Basalt

2. Callovian-?- Oxfordian greenish-gray limestone

3. Late Jurassic red clayey limestone

4. Tithonian-iveocomian white and gray limestone

5. Tithonian-Neocomian calcareous ooze and chalk

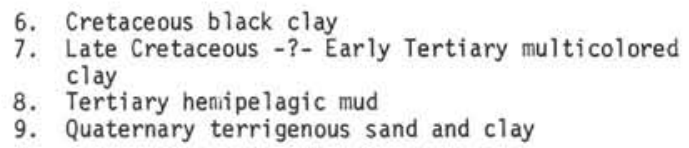

Figure 2. Schematic distribution of the different facies recognized (synthetic sketch based on data from drilling and seismic profiler records in the North American basin).

The basalt-sediment contact was recovered at both sites.

At Site 100 the contact between the basalt and the middle or upper Jurassic greenish-gray limestone is very sharp and lacks evidence of contact metamorphism.

Inasmuch as the limestone is rather well lithified, it is improbable that any sediment that might have been in contact with the basalt was washed out during the coring operation, and the sequence recovered in Hole 100 , Core 10 is believed to contain the true contact (see color picture on the frontispiece of this volume). Microscopic examination of the sediments confirmed the lack of any effects of contact metamorphism. The composition and structure of the sediments show no variations toward the bottom of the section. No increase in the amount of the recrystallized calcite near the contact or evidence of any kind of metamorphic effect or mineral enrichment was observed.

The topmost 2 centimeters of the basalt is very rich in glass, and the glassy surface of the rocks is similar to that of some basalts dredged near the crest of the East Pacific rise (Bonatti, 1967).
Several limestone inclusions occur in the upper part of the basalt section. They all have identical composition and texture and consist of a finely recrystallized micritic limestone. One of them yielded a few microfossils of the same age as those of the overlying sediments.

At Site 105 the sediments in contact with the basalt are slightly younger than at Site 100 and are considered to be of Oxfordian age.

The contact zone differs from that at Site 100 and shows the following successive layers (from top to bottom) (see Figure 3):

1) Red, clayey Oxfordian limestones, undisturbed, and containing rare dispersed pyroclastic pebbles. These clayey limestones are relatively soft, and some of the section just above the brightly colored claystones may be missing-washed out by the high water pressure used for coring of hard rocks. 


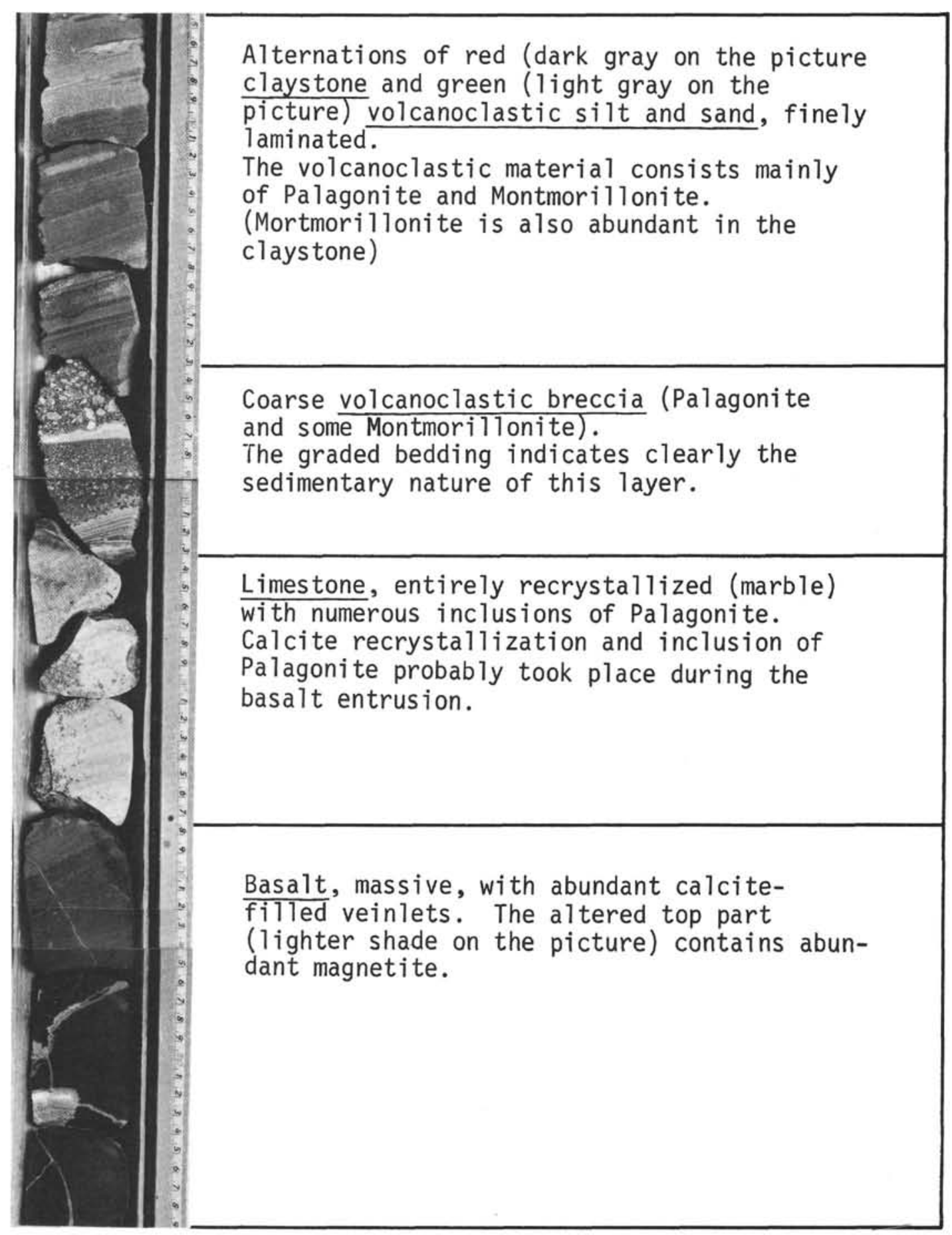

Figure 3. The contact between basalt and sediment at Site 105. 
2) Brightly colored laminated zone, red and green, consisting of interbedded, well-indurated clay (red) and palagonite-rich thin layers (green) (Figure 4). Most of the palagonite is altered to montmorillonite. The clay contains abundant sanidine. This high temperature potassium feldspar appears to be authigenic or to be replacement of volcanic shards (Figures 5 and 6).

3) Palagonitic tuff, 12 centimeters thick, showing distinct sedimentary structures, laminated at the base, graded-bedded in the middle part, and brecciated at the top. This tuff consists mainly of small palagonite pebbles cemented by a wellcrystallized calcite matrix.

4) Completely recrystallized (marble-like) limestone, green to pink and pale red, containing abundant dark-green palagonitic clasts. Most of this limestone consists of well-crystalized highmagnesium calcite. This zone is about 15 centimeters thick.

5) Basalt, massive, containing abundant calcite veinlets.

As at site 100 , some limestone inclusions were found in the basalt. They are composed of recrystallized calcite containing some palagonite fragments, and they resemble the pink limestone found near the contact between basalt and sediment.

\section{Structure of the Basalt}

The composition and texture of the basaltic rocks are slightly different at Site 100 and Site 105, but at both sites the basalt appears to have a hyalo-ophitic structure, with numerous labradorite laths, sometimes replaced by magnetite, pyroxene, very rare olivine, and abundant brown glass (for details see article by W. B. Bryan, this volume).

The most important difference between the cores from the two sites is in the structure of the basalt. At Site 105 the entire section is rather massive, and pieces about 30 centimeters long could be cored without breaking, whereas at Site 100, massive pieces are separated by highly fractured zones in which a net of thin black glassy veinlets can be observed. These veinlets as well as the calcite veinlets produce lamellar and curved structures that strongly suggest the presence of pillow lavas. The differentiated structure of the basalt at Site 100 then could result from the accumulation of several thin flows, or else be related to differentiation inside a flow. The viscosity of the lava at Site 105 was probably greater than that of the lava from Site 100, which may account for the difference of sound velocities measured in the basalt from the two holes (see article by Schreiber and Fox in this volume).

\section{Interpretation and Discussion}

At Sites 100 and 105 the basalts probably represent extrusive flows rather than sills, and represent the true basement as it is interpreted on the seismic profiles.

At Site 100, the structure of the basaltic rock, its glassy top surface, and the lack of any metamorphic effects in the sediments suggest that the middle or Upper Jurassic limestones were the first sediments deposited on the already cooled surface of a lava flow.

At Site 105, the features of the contact zone can be explained as follows:

a) The green and pink limestones directly overlying the basalt were the only sediments encountered by the lava when it flowed on the sea bottom. At this time the recrystallization of the calcite in the sediments and the incorporation of palagonitic material took place. These sediments may have been carried some distance by the lava flow. The incorporation of abundant dispersed palagonitic fragments inside the sediments supports this interpretation.

b) Just after the deposition of the flow, volcanic fragments were ejected into the sea water and deposited on the top of the flow and the associated metamorphosed sediments. These volcanic clasts may have been produced either by the same volcanic event that produced the flow or by a later nearby eruption.

c) The deposition of clays interbedded with palagonite-rich layers took place. The high montmorillonite content of the clays suggests that they formed by the alteration of volcanic glass.

d) Finally, the clayey red limestones were deposited and represent the essentially first nonvolcanic sedimentation. Scattered palagonitic clasts occur in these sediments in amounts which decrease upward. This decrease suggests a diminishing volcanic influence, probably the result of an increasing distance from the active rift zone because of sea-floor spreading.

The rocks recovered at the bottom of Holes 100 and 105 suggest that at both sites the oceanic basement is made of basaltic flows. Other observations in the Atlantic and Pacific provide evidence that the acoustic basement may often consist of sills (Peterson et al., 1970; Hays et al., 1970; Laughton et al., 1970; Hayes et al., 1970; and McDougall, 1971). The formation of the oceanic basement is probably the result of volcanic activity in which local intrusions as well as extrusions might have occurred in an active zone several kilometers wide on both sides of the axis of the rift by a process similar to that described for the formation of abyssal hills in the Pacific (Moore and Heath, 1967). 


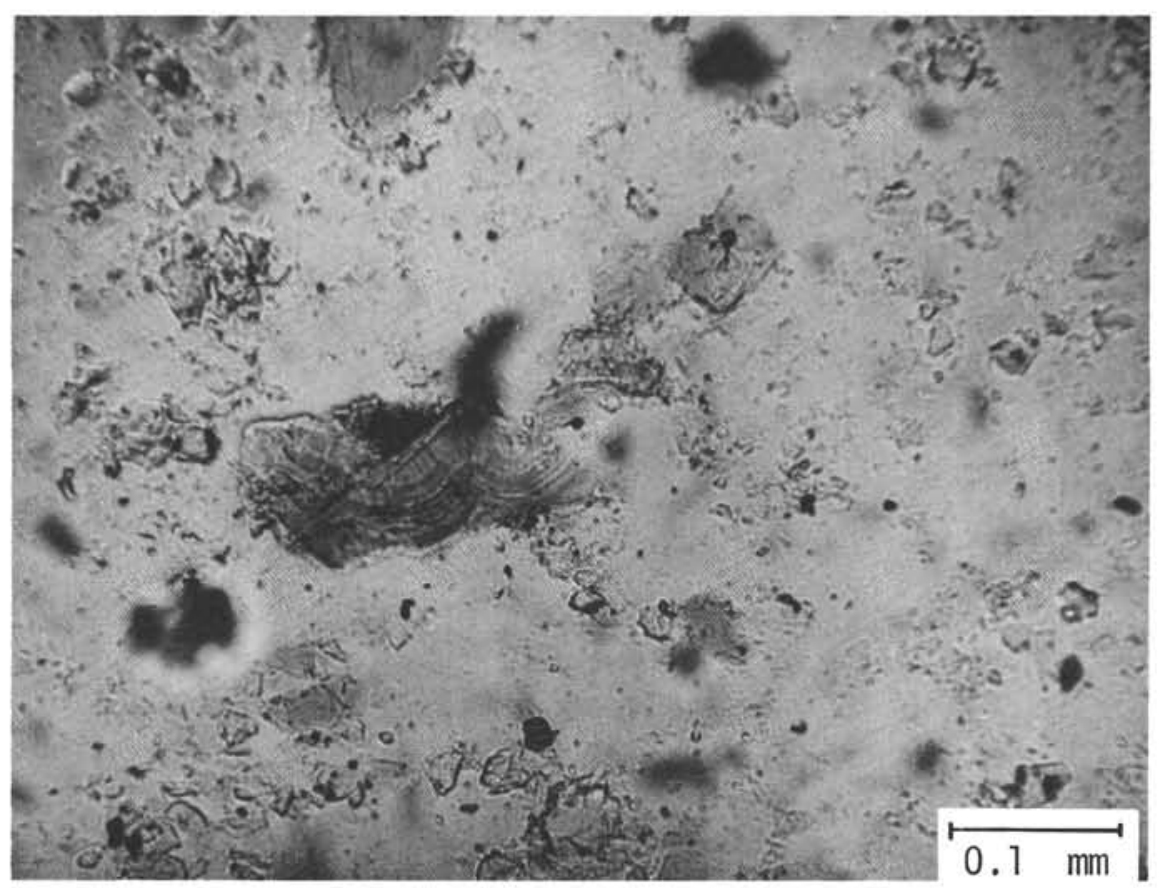

A

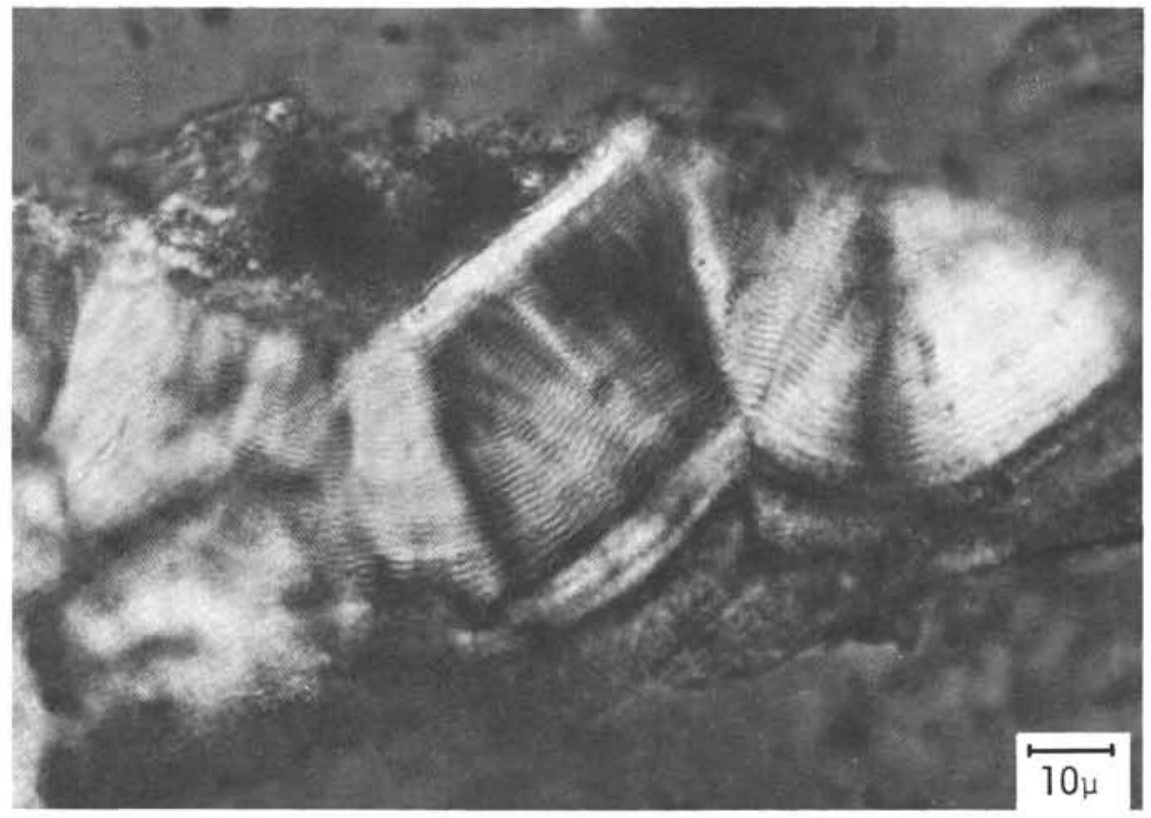

B

Figure 4. Photomicrographs of palagonite A. Palogonite fragments from Sample 105-40-1, $60 \mathrm{~cm}$, plane polarized light. B. Same showing moiré-like patterns in palagonite grain, crossed polarizers. 


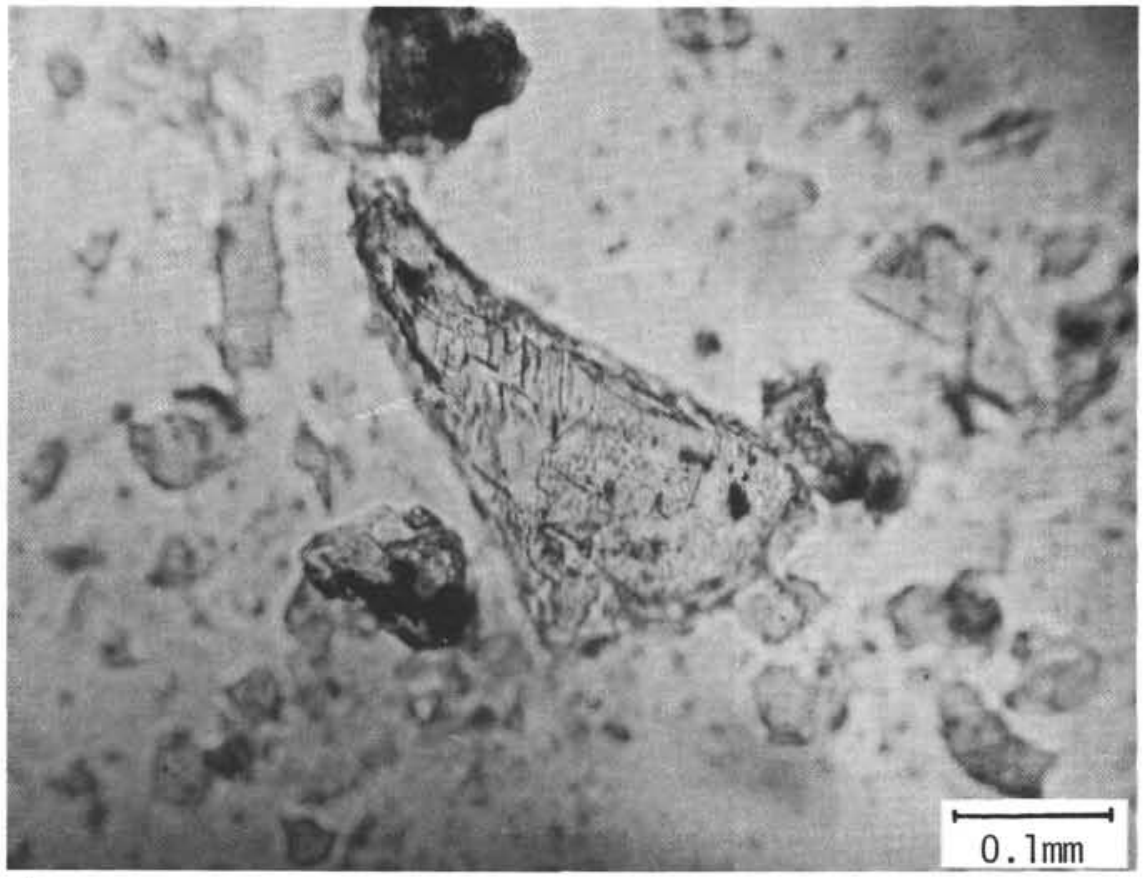

A

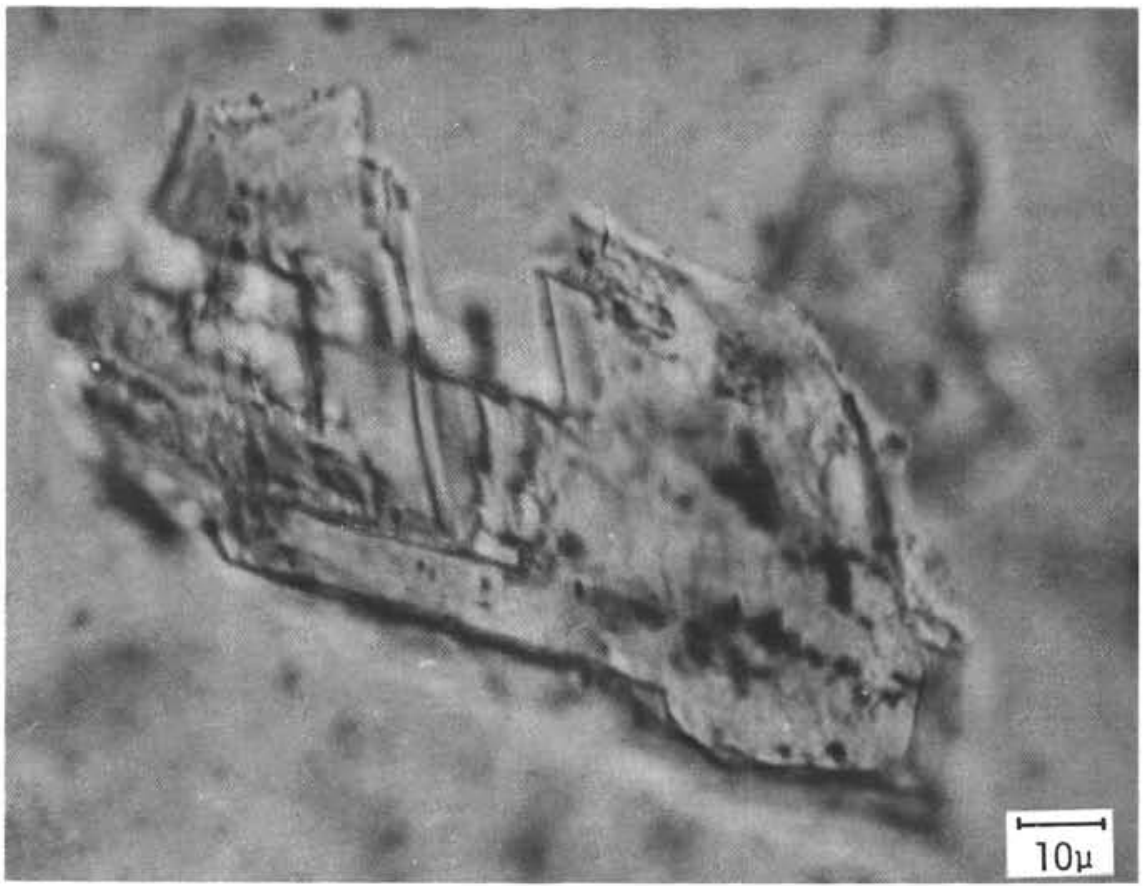

B

Figure 5. Photomicrographs of sanidine from Samples 105-40-1, $84 \mathrm{~cm}$ (A) and $85 \mathrm{~cm}(B)$, showing authigenic growth or replacement of glass shards; plane polarized light. 

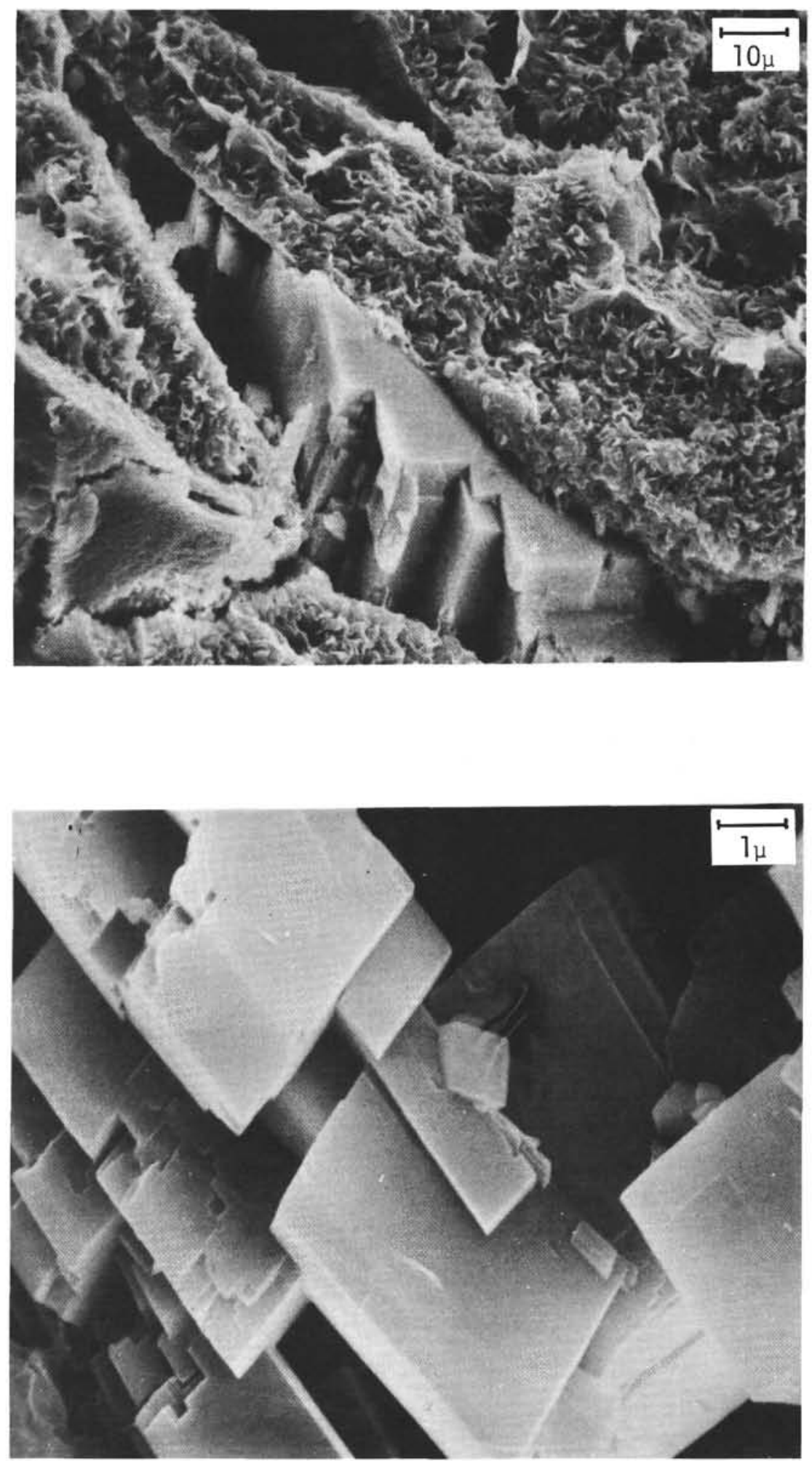

Figure 6. Scanning electron micrographs of sanidine from Sample 105-40-1, 77 to $78 \mathrm{~cm}$ showing authigenic growth or replacement of shard structures. Matrix in top view is montmorillonite in palagonite-like structure. 
At Site 100, the smoothness of the basement might have resulted from more fluid extrusions, extending over longer distances than at Site 105.

\section{THE "OLDEST" SEDIMENTS, GREENISH-GRAY HOMOGENEOUS LIMESTONE}

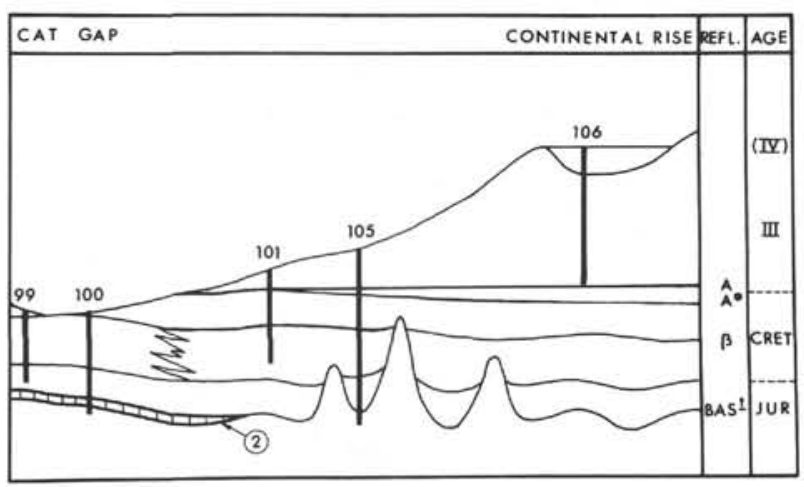

At Site 100, the sediments recovered at the contact with basement rocks consist of rather homogeneous greenish-gray limestone of Callovian or Oxfordian age. This facies is about 40 meters thick and grades upward to the red clayey limestone facies of Oxfordian age. The lateral extent of the facies is unknown and the facies is not differentiated acoustically on the seismic profiles from the overlying reddish limestones. However, we assume that it could be present at Site 99 and in most of the Cat Gap area, as no significant changes in thickness were observed in the basal limestone on the continuous seismic profiles. No limit was observed toward the north, but these limestones are not present at Site 105 where the red limestone facies was found directly above the basalt.

\section{Sedimentary Structures}

The lower part of the section is homogeneous, with only rare faint laminations marked by slight changes of coloration. The only apparent structures are worm burrows and numerous dark streaks and specks of carbonaceous matter. Most of such streaks on horizontal breaking planes of the cores are plant debris. They consist of small leaves, twigs, and stems. Some of this material has been almost entirely replaced by pyrite and is only outlined by a film of carbonaceous matter.

The upper part of the section (Hole 100, Core 7) shows abundant structures such as laminations, burrows, and minor current bedding. In a few places white clasts of pelagic material are sometimes associated with these structures.

The whole section is well indurated except for some more clayey zones in which apparent bedding and laminations are artifacts due to disturbances created by the coring operation.

\section{Composition}

The main constituent of these limestones is recrystallized micritic calcite. The calcium carbonate content varies from about 50 percent in the more clayey zones to about 85 percent. Terrigenous components, mainly clay minerals, are relatively rare except in some preferentially softer zones; organic matter is regularly present; calcareous microfossils are surprisingly scarce, and we believe that they have been the source for the recrystallized calcite.

Some of the recrystallized calcite is in the form of small elongated grains (Figure 7) which are probably euhedral crystals.

Partial results of X-ray determination of the clay minerals indicate abundant montmorillonite in the lower part of the section. The occurrence of this mineral just above the basement suggests some volcanic activity in the area.

\section{Lithification and Diagenesis}

These limestones appear well lithified and relatively hard, but their cementation is only partial, and they generally have a slightly porous and chalky aspect. The more lithified zones are associated in many places with the occurrence of small grains of recrystallized calcite.

Other than this calcite, the only observed results of diagenetic processes are pyrite and hematite. Pyrite probably formed in small reducing microenvironments associated with local concentration of organic matter. The origin of the hematite is discussed below in the section on upper Jurassic red limestones.

\section{Discussion}

The first sediments to be deposited on the oceanic crust in the southern part of the North American basin were carbonate pelagic oozes, containing abundant well preserved organic debris and little terrigenous detritus. This indicates a relatively calm environment above the carbonate compensation depth that existed at the time. Lithological observations alone do not reveal the water depth during the formation of these sediments. However the increasing amounts of benthonic foraminifera and the nature of the ostracodes in the lower layers indicate relatively shallow, although still upper bathyal, conditions (see Luterbacher, this volume). 

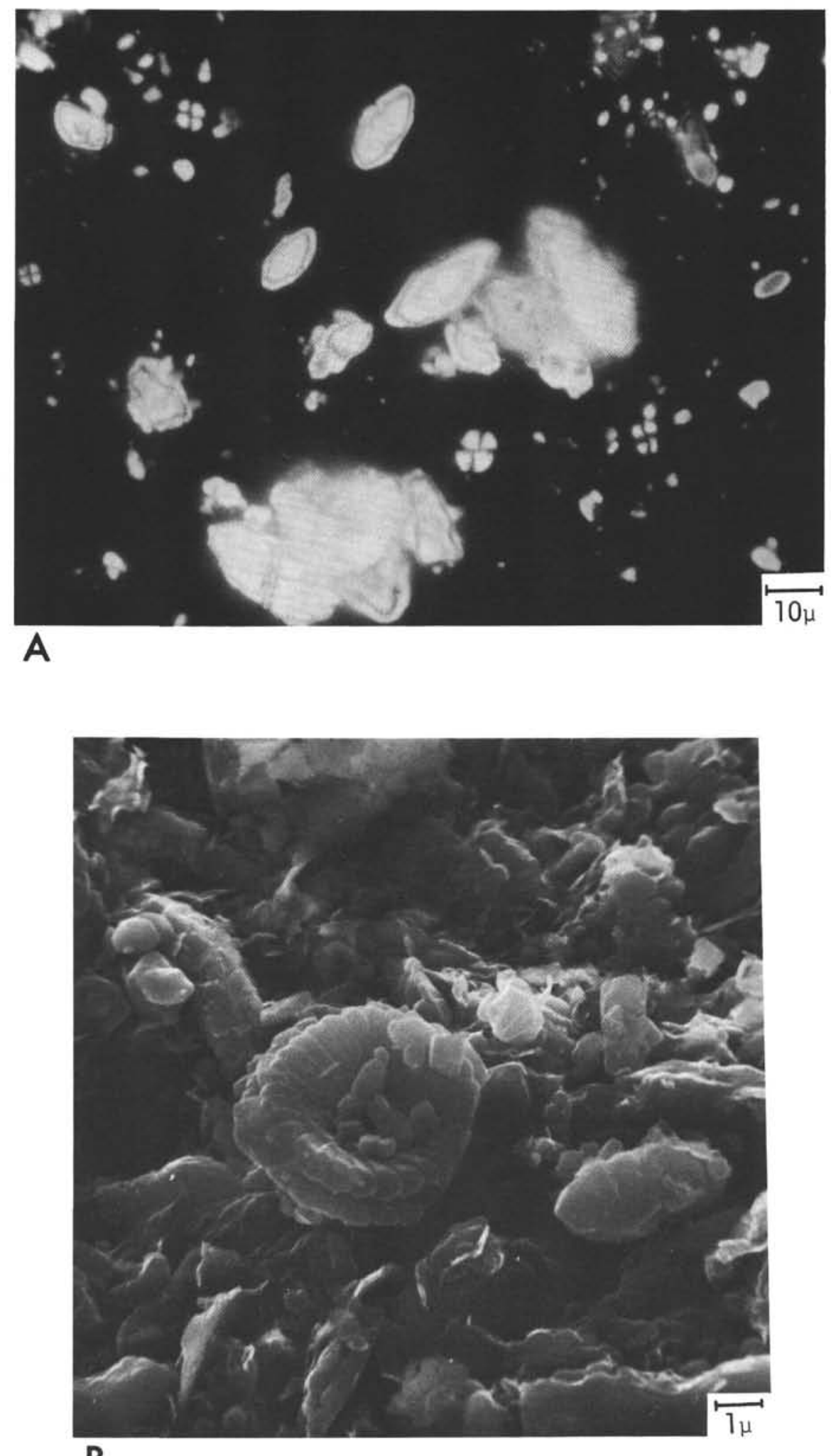

B

Figure 7. Recrystallization of calcite in upper Jurassic limestone.

A. Photomicrograph of calcite scalenohedra (?) in Sample 100-2-2, 0 to $1 \mathrm{~cm}$ (crossed polarizers).

B. Scanning electron micrograph from Sample 100-7-1, $111 \mathrm{~cm}$ to $120 \mathrm{~cm}$ showing abundant small recrystallized calcite crystals. 
The lack of any specific metamorphic effects near the basalt at Site 100 and the absence of volcanic detritus such as palagonite, glass shards, zeolites, and pyroclasts suggests that the deposition took place in an area relatively distant from the active rift zone. Distant volcanic activity could be the source of montmorillonite in the lower layers. In the upper part of the section, some laminations, discrete flow structures, and pelagic clasts show that some minor displacements of carbonate-rich sediments took place after deposition of the homogeneous layers. The carbonate-rich sediments probably formed on the topographic highs, whereas finer grained detrital clay materials settled in the low areas. This may have resulted from an increasing tectonic activity which produced topographic irregularities, and by some faint bottom-current circulation which winnowed the finest grained materials from the topographic highs.

\section{THE OXFORDIAN-KIMMERIDGIAN RED CLAYEY LIMESTONES}

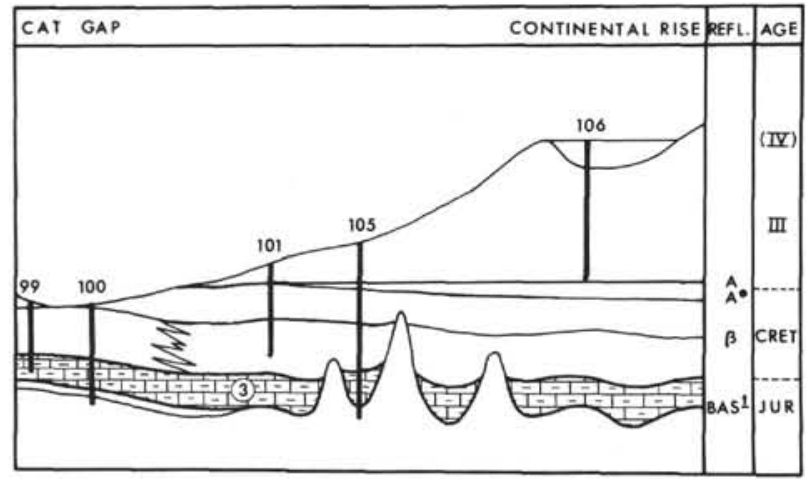

Brick-red clayey limestones of Oxfordian to Kimmeridgian age were recovered at Sites 99, 100 and 105. They overlie the Callovian or Oxfordian greenish gray limestones at Site 100, whereas they are the oldest sediments recovered from the two other holes. They are directly in contact with the basalt at Site 105, but whether some Callovian or Oxfordian is present at Site 99 between the red limestones and the basalt is unknown. Although the recovery was rather poor at Site 99, sedimentary structures, color, and composition of these sediments are similar for the three sites.

The thickness of this facies is about 70 meters at Site 105 and about 40 meters at Site 100 . At Site 99 the vertical extent of the facies is unknown, but the similarity of seismic profiles of Sites 99 and 100 suggests that no major variation in thickness occurs between the two sites. Profiles in the vicinity of Sites 99 and 100 (see Site Reports) show a weak but distinct reflector at about 0.1 seconds above the basement reflector. This reflector may correspond to the top of the red limestones, which are apparently the only well-lithified sediments in the section. This reflector can be followed from Site 99 to Site 100, and in the general area where these holes were drilled. At Site 105 the picture is somewhat different, because of the roughness of the basement topography (Figure 6). No distinct reflector seems to mark the top of the red limestones, as the overlying sediments are also well lithified, but if we assume that the thickness ratio of these red layers versus the total thickness of the limestones remains approximately constant, important variations in the thickness of the red limestones must exist. This formation is then not parallel to the basement but is discontinuous and restricted to the deeper parts of the inter-hills depressions. This difference between the two areas is reflected in some of the sedimentary structures at Sites 100 and 105.

The facies of the red limestones is strikingly similar to some of the "ammonitico rosso" (sensu lato) facies in the Jurassic outcrops of the Mediterranean Tertiary chains. D. Bernoulli (this volume) compares the two formations in detail.

\section{Origin of the Red Color}

Iron oxide in the form of hematite is associated with the fine-grained components of these sediments and gives them the conspicuous red color. Organic material in some layers or zones resulted in reduction and removal of this iron oxide and allowed the green color to appear. In many places these spots and zones are independent of bedding planes. The coarser-grained zones and highly calcareous zones are usually lighter colored than the fine-grained or clayey zones, suggesting that the iron oxide was either preferentially adsorbed on clay minerals or simply so fine-grained that it tended to be deposited wherever the finestgrained materials accumulated.

The iron may have had an origin similar to that of the amorphous iron oxides reported by Bostrom and Peterson (1966), Bostrom et al. (1969), von der Borch and Rex (1970), and von der Borch et al. (1971). These authors postulate that amorphous iron oxide precipitates from sea water as the result of metal-rich volcanic exhalations in the vicinity of mid-ocean ridges. At Site 105, at least some of the iron oxide is crystallized as hematite and thus differs from the amorphous material reported by the above authors. Perhaps the greater age of the Site 105 material as opposed to the Tertiary or younger ages of the materials reported by the authors cited above accounts for this difference. 


\section{Sedimentary Structures}

All these rocks are relatively well lithified and, except at Site 99, recovery was rather good and sedimentary structures are exceptionally well preserved. Many of the structures are marked by color changes due to differences in the clay content and the oxidation state of the iron. Generally, the most fine-grained parts are red to brownish-red, whereas, patches and bands of light green are found in the coarser layers and around clasts, microfossils, and microfissures.

Figure 8 shows a comparison of the sediments recovered from Site 100 and Site 105 in this formation.

A very wide range of structures was observed, from relatively homogeneous pelagic sediments with burrows and faint laminations, to well-laminated layers, flow structures, "pelagic" turbidites, and large slumps.

a) Homogeneous and laminated layers (Figures 8 and 9).

These beds show thin, generally horizontal laminae; sometimes the beds are slightly undulatory. They consist of thin (about 1 millimeter) alternations of red clayey layers and white, more calcareous layers. Very often they contain abundant burrows, which suggests a relatively slow rate of sedimentation and oxidizing conditions at the water-sediment interface. The thin laminae suggest a very calm environment.

b) Flow structures and current bedding (Figures 9 and 10).

In some layers the laminations are more disturbed, and every step between undulatory laminae and microfolded or microfaulted laminae occurs.

Small white clasts are often associated with these structures. They consist of pelagic material, usually indurated and rounded pebbles of carbonate ooze. Their size ranges from 1 millimeter to about 1 centimeter. None of them was found to be of a shallow-water origin, and we believe that they come from local topographic highs and have been incorporated in the clayey sediments during local displacements and penecontemporaneous disturbances associated either with bottom currents or with gravity slumping and sliding.

c) "Pelagic turbidites" (Figure 9A and 9B).

The adjective "pelagic," associated here with the term "turbidite," refers to turbidites comprising only resedimented pelagic material deposited by local turbidity currents.
A typical sequence follows (Figure 9B, from bottom to top):

Mud pebbles, in some places as red as the clayey matrix and of the same composition, in other places white and of almost pure carbonate ooze, generally recrystallized, containing occasional calcitized radiolarians. The pebbles are often partially flattened by compaction, and obviously they were still unlithified at the time they were deposited. Some are in a matrix in which flow structures occur.

Sand and silt sized particles, displaying graded bedding and often rather well sorted. These usually occur as green and white layers in the red sediment, and therefore are easily distinguished. The color difference was probably caused by diagenetic reduction of the iron in the presence of organic matter and perhaps by preferential circulation of the interstitial water in these relatively more porous layers. This preferential circulation may be responsible for the formation of chert in one of these coarse-grained layers. In some places the sorting is poor, and no color change occurs. In some layers, the main components are small shells of pelagic lamellibranchs; in others, they are almost exclusively pelagic crinoid fragments (Saccocoma). Usually the layers show a mixture of these fragments and small calcareous clasts. Toward the lower part of the section, some volcanic clasts occur.

Homogeneous layer, brick red, devoid of any structure. The characteristic feature of most of this upper part is the lack of burrow mottling. This suggests that the sediment was deposited very rapidly and probably represents the top fine-grained part of the sequence.

At the top of the terminal layer, burrows and some laminations occur. This represents the "normal" pelagic interval which may be interrupted again by another turbidite sequence or by slump or flow structures.

The sequence may not always be complete and one of the layers may be absent (often the pebble layer). In other places some repetitions, or recurrences, of the sand/silt-size layers occur.

\section{d) Slump structures (Figure 10).}

Large slump structures appear in several sections from the upper part of the sequence. All the beds show major disturbances, such as, disruption of laminae, folding, faulting, and truncation. Some structures are difficult to recognize owing to the relatively small diameter of the cores, but a careful examination of some apparently regularly laminated layers shows the occurrence of microshearing and, in some places, evidence of large-scale plastic deformation, such as folding, faulting, and other disturbances. Some of the slumped beds are several meters thick. 


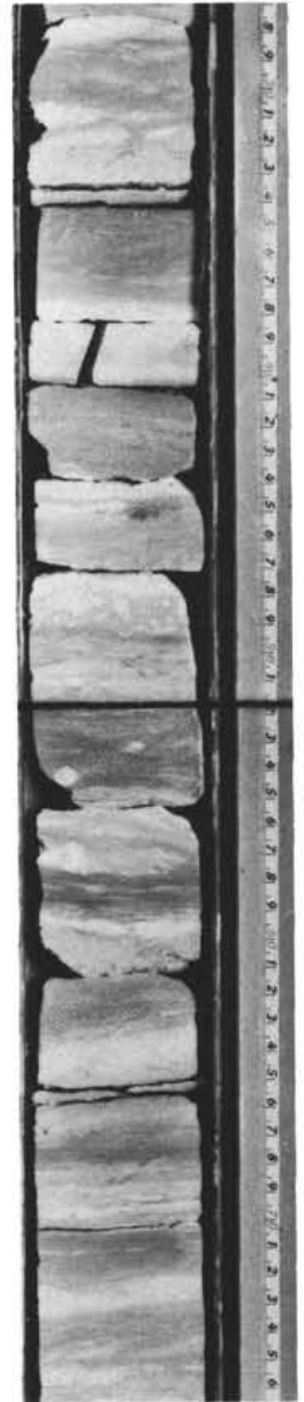

$100-2-2$

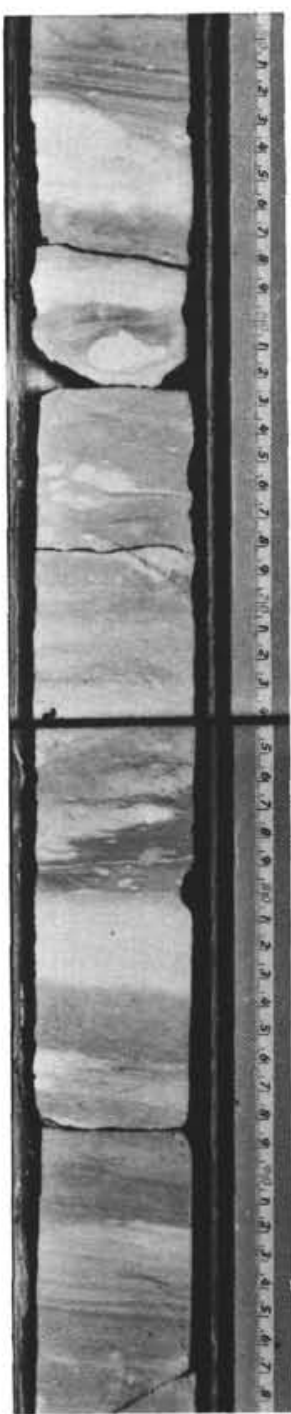

105-33-4

Figure 8. Comparison of the Kimmeridgian-Oxfordian limestones recovered from Sites 100 (Cat Gap area) and 105 (Lower Continental Rise, approximately 690 nautical miles $N-N E$ of Site 100)the light colored clasts and layers on the picture are pale pink to pale green, the darker zones are brownish-red.

e) Macrofossils and extraclasts.

Numerous macrofossils were found throughout this section, among them the numerous large aptychi which are described in this volume by $\mathrm{O}$. Renz.

Volcanic clasts are relatively abundant in the lower part of the formation. They consist of small ( 0.5 to 1.5 centimeters) dark-green pebbles of palagonite. Their amount decreases regularly upward.

f) Differences between the sedimentary structures from the northern and southern areas.
Although the correlation between Sites 99, 100 and 105 is very good, some differences exist in the relative abundances of sedimentary structures. The southern sites show mainly laminated sediments, numerous flow structures, and a few small-scale turbidites and microslumps. The well-developed turbidite sequences and the large slumps were observed only in the north (Site 105), where the lower part is dominated by turbidites; slumps are especially important in the upper part of the section. These differences may be easily related to the basement topography which, as was noted above, is much rougher at Site 105; there, important displacements of sediments are responsible for filling of interhill depressions. 


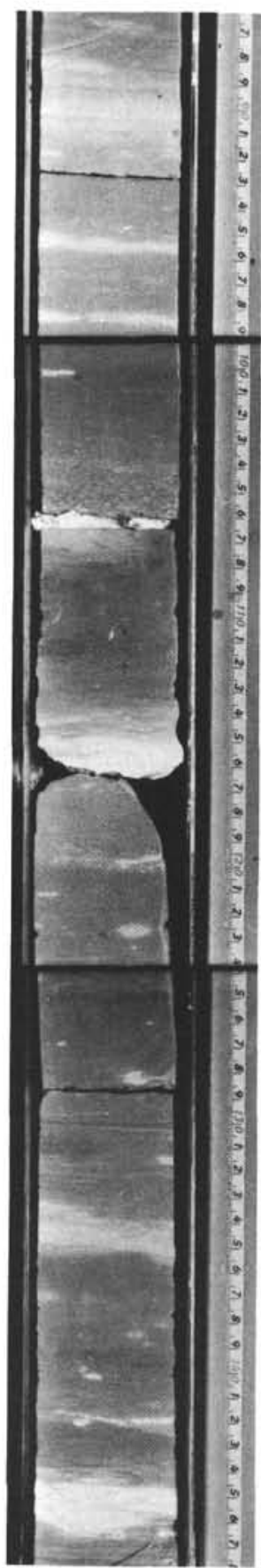

$105-37-2$

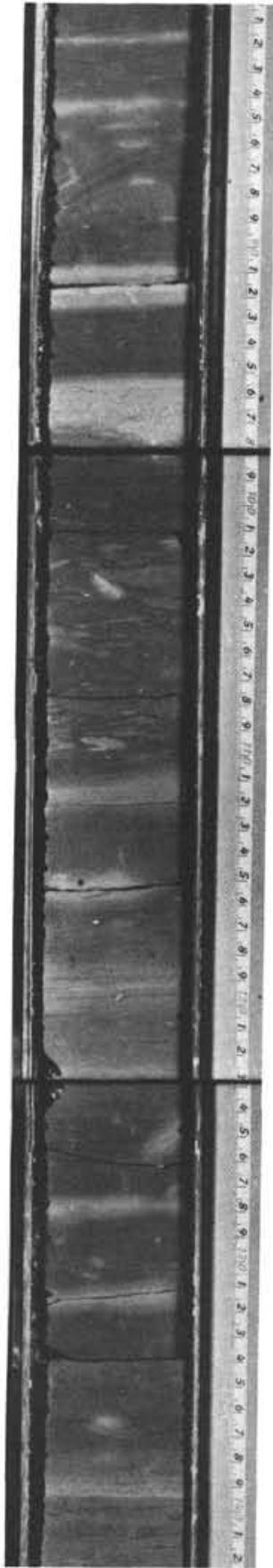

$105-37-5$

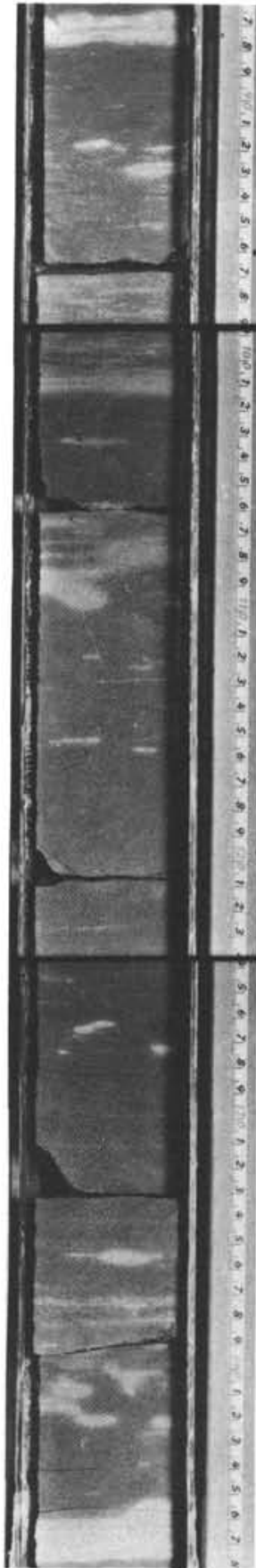

$105-37-6$

Figure 9A. "Pelagic Turbidites" in the upper Jurassic (Oxfordian) red and green clayey limestone at Site 105. See Figure $9 B$ for more details.

\section{Composition}

The composition of Upper-Jurassic red clayey limestone beds was determined by smear slide examinations and by the results of X-ray diffraction analysis (for more detailed information see Site Reports and chapter by Zemmels, Cook, and Hathaway in this volume).

\section{Carbonates}

The composition of the clasts and that of the matrix differ. The clasts-white, pink or pale green-are almost pure calcium carbonate (around 90 per cent). They contain variable amounts of foraminifera, calcitized radiolarians and coccolith fragments, but the dominant 


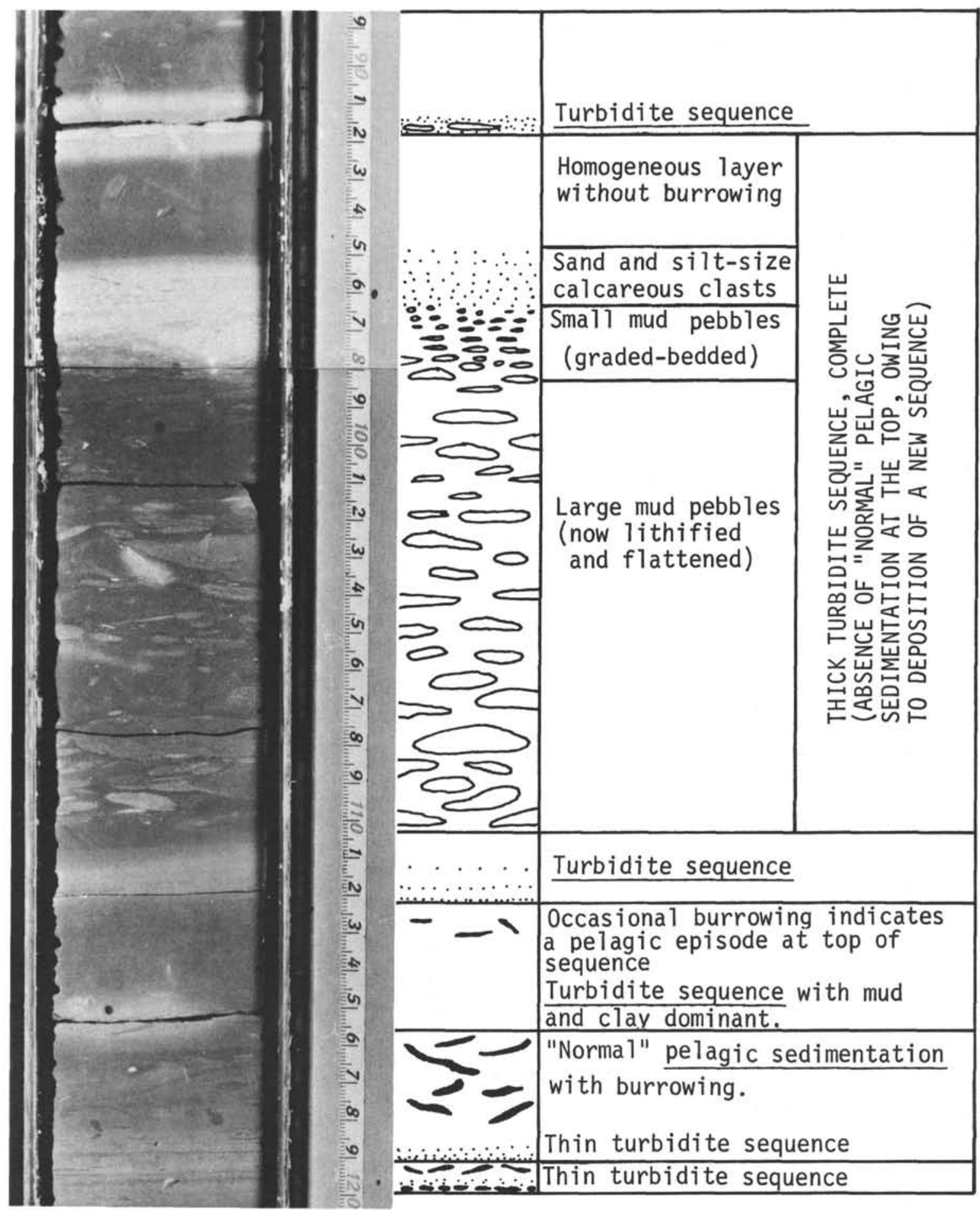

Figure 9B. "Pelagic Turbidites" from the upper Jurassic (Oxfordian) red and green clayey limestone at Site 105: detailed description. (Core 37, Section 5).

component is recrystallized (micritic) calcite. The matrix-red and argillaceous-has a calcium carbonate content ranging generally from 20 to 70 percent, and contains abundant clay minerals, coccolith fragments, and rare foraminifera. Recrystallization of the calcite is much less important than in the clasts.

\section{Clay Minerals}

Appreciable amounts of palygorskite have been found in samples from Site 100 associated with some montmorillonite. Palygorskite has been reported in deep sea sediments by various authors and the problem of its 
origin in this kind of environment is still under discussion (see for example Hathaway and Sachs, 1965; Heezen et al., 1965; Siever and Kastner, 1967; Bonatti and Joensuu, 1968; Chamley and Millot, 1970; Peterson et al., 1970; Hathaway et al., 1970; Zemmels et al., this volume).

\section{Quartz}

Quartz is regularly present in most of the samples; its amount varies from 2 to 30 per cent with an average of about 10 per cent. Part of this quartz could be of diagenetic origin (silicified) microfossils).

\section{Feldspars}

Plagioclases and occasional microcline are present in minor concentrations. They are often associated with quartz and sometimes with mica and chlorite and should thus be considered as detrital. The occurrence of sanidine in several samples from the layers just above basalt at Site 105 is remarkable. This hightemperature potassium feldspar has been reported from deep-sea sediments of the eastern Pacific Ocean by several authors, beginning with the original Challenger reports (Murray and Renard, 1891); the problem of its origin and of its possible relationship with acidic rocks from the eastern Pacific has been discussed by Arrhenius and Bonatti (1970). These authors stated that the sanidine crystals probably result from the differential destruction of abyssal acidic effusive rocks, and are the only remainders from otherwise entirely decomposed eruptive bodies. They suggested that the production of acidic effusive rocks could have been related to periods of poorly active mantle upwelling in the rift zones. There are no indications of acidic effusive rocks in any of the drilled sites in the northwest Atlantic, however, and scanning electron micrographs of the sanidine (Figure 5) clearly indicate its authigenic characteristics. We consider the sanidine and the accompanying montmorillonite to be the result of the alteration or devitrification of pyroclastic material, which is in turn a late-stage differentiation product of a basaltic magma.

\section{Heavy Minerals}

Some rare detrital grains of pyroxene were found occasionally, especially at Site 105, but the major heavy mineral is rutile, often very fine grained, generally present as thin needles, some with typical twinning. Rutile seems to be associated with iron oxides (especially hematite). Iron and titanium show a correlation in deep-sea brown clays of the Pacific Ocean (see for example, Pimm et al., 1971), which suggests a similar origin for these elements.

\section{Hematite}

Hematite is regularly present in the clayey layers and is responsible for the red color of the clayey limestones.
It is sometimes in the form of small crystals, but is more generally finely dispersed and stains the clay minerals. There are two possible origins for these high concentrations of ferric iron. The first explanation would require a detrital source and would imply important weathering of exposed "lateritic" facies in the peri-Atlantic continental areas. Another possible source of ferric iron would be the nearby submarine volcanic activity, associated with sea floor spreading in the young Atlantic basin, following processes similar to those described by Bostrom and Peterson (1966) in the East Pacific Rise area. The following observations lend support to the second hypothesis:

1. There is evidence of hydrothermal activity in the sediments even several meters above the contact with basaltic rocks (presence of barite and native copper).

2. The iron does not seem to be associated with any specific clay mineral of detrital origin.

3. Terrigenous detritus is generally poorly represented in these limestones.

4. Similar association with a rifting area could be reasonably proposed for most of the comparable Jurassic facies, from Cuba to the south of Spain and the southern Alps.

Actually the sediments described here seem to have a composition that could be compared with that of the "ridge flank" sediments, out of the high heat-flow values area.

\section{Glass and Palagonite}

These components are present only at Site 105 . Light-colored glass shards are rare, whereas palagonite (generally green) is relatively abundant in the lower part of the section. It decreases in amount regularly upward but was found as high as Core 34 .

\section{Barite}

A lens of well-crystallized barite was found at Site 105 in Core 33.

\section{Native Copper}

A small vein of native copper is present in Core 38 at Site 105 . This vein is about 0.5 -millimeter thick and extends about 25 millimeters vertically, cutting through part of a turbidite layer. Some small clusters of copper crystals are surrounded by palagonite-like material. Its origin is probably hydrothermal.

\section{Carbonaceous Matter}

Carbonaceous matter is rare in these sediments; however, a substantial amount is present at Site 100 in the 


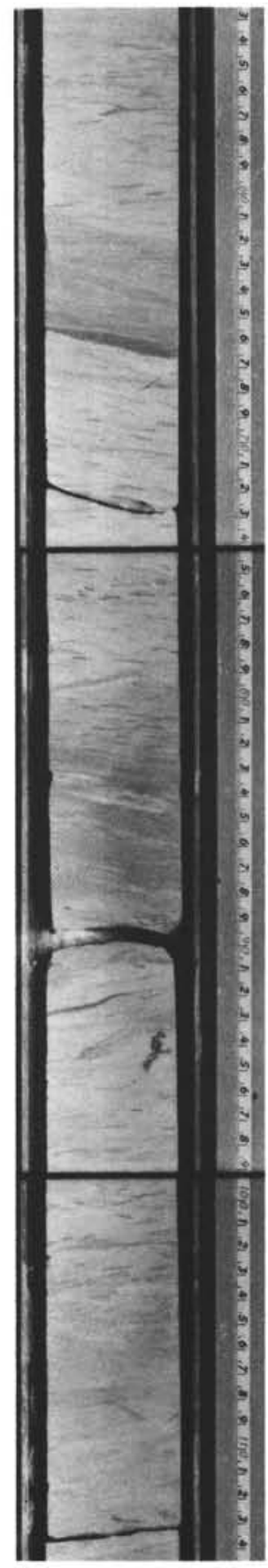

$105-27-2$
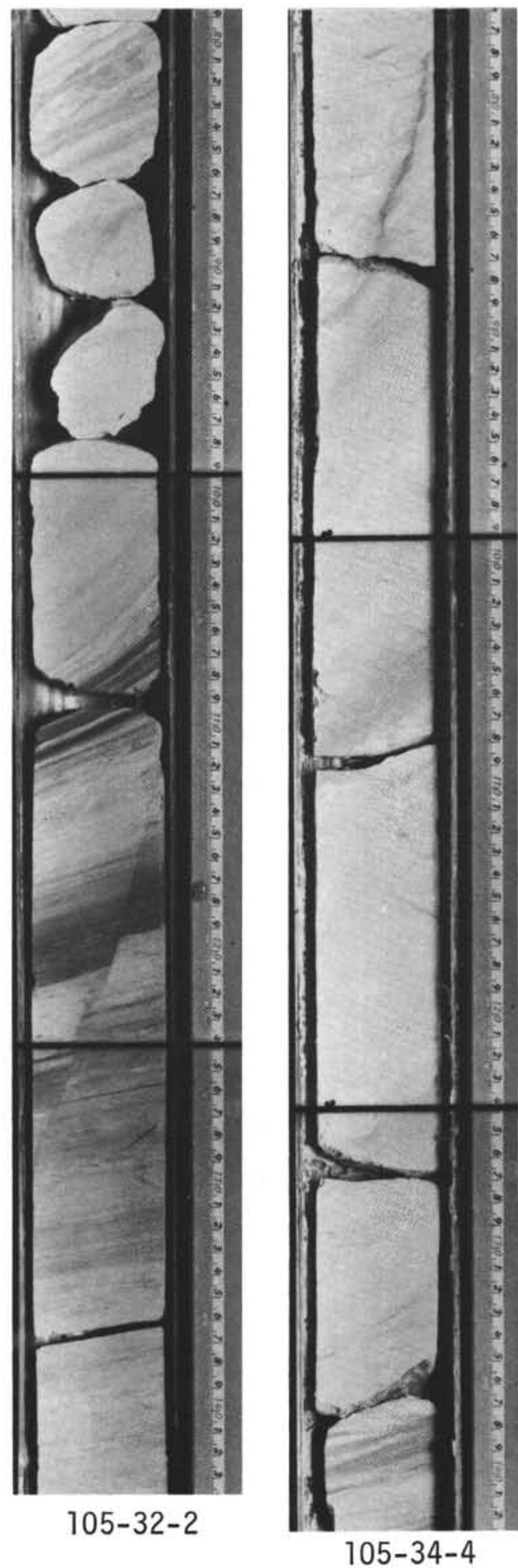

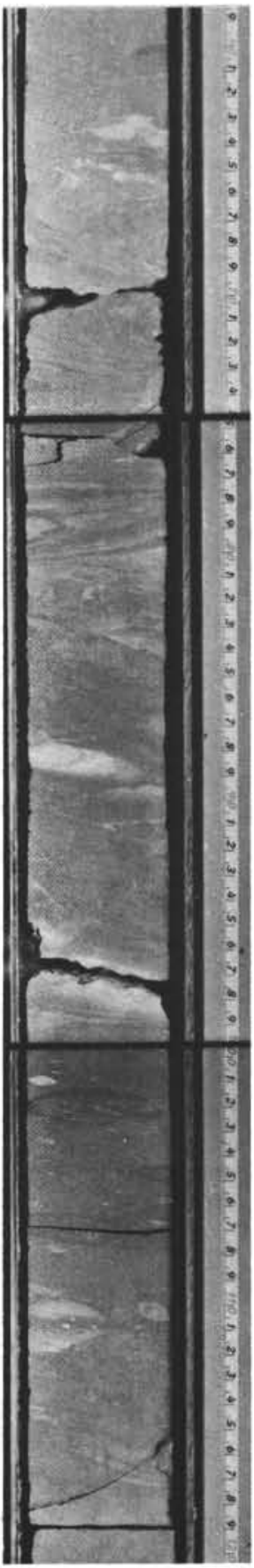

$105-27-3$

Figure 10. Slump Structures from upper Jurassic-lower Cretaceous limestones at Site 105. Note the "blurred" aspect of the burrows in 105-27-2, due to micro-shearing structures caused by slumping of the entire section. 105-27-3 and 105-32-2 are parts of several-meters thick massively slumped layers. Note also the smaller scale of the structures in 105-34-4. 
lower part of this section. As the last core of Hole 99A shows the same composition, it may be inferred that it has sampled the same level at Site 100 and that Hole 99A bottomed very close to the top of Callovian or Oxfordian greenish-gray limestones in which carbonaceous matter was regularly found.

\section{Lithification and Diagenesis}

In general the lithification of these red limestones is relatively poor compared with that of the over-and underlying limestones. The poorly lithified layers have high clay content. The clay minerals, filling the micropores of the sediment, may have prevented the dissolution and recrystallization of the calcite. Only the clasts, which have a very high carbonate content, have undergone much cementation. Smear slides show that the clasts contain abundant micritic recrystallized calcite but only rare to common calcareous nannoplankton, whereas in the red matrix the relative abundance of these elements is reversed. The clasts were probably not lithified when they were incorporated in the clayey matrix (see article by Bernoulli in this volume).

Chert occurs at Sites 99,100 and 105 as relatively thin layers or nodules ( 2 or 5 centimeters). At Site 105, several smear slides made from slightly silty layers showed discrete silt- and sand-size chalcedony spherules which are probably filled and recrystallized radiolarians, and which could be considered as "microchert". At the same site, the only chert layer present is clearly associated with the sand-size part of a "pelagic turbidite". It consists of a graded bed in which the main constituents are plates of pelagic crinoids (Saccocoma), showing calcite overgrowth, containing abundant calcitized Radiolaria, and cemented by a matrix of chalcedony. In this case, the chertification probably took place preferentially in this coarsegrained layer because of circulation of interstitial water. The sparry calcite overgrowth that surrounds the crinoid plates, which is very rarely observed in deep-sea sediments that have not been exposed to weathering, may also be related to this preferential circulation in a coarse-grained layer.

\section{Discussion}

Correlation, based on color, sedimentary structures, composition, and age, is possible between the red clayey limestones recovered at Sites 99, 100 and 105 . These sediments resemble so closely the "ammonitico rosso" and "rosso ad aptychi" facies from the periMediterranean Tertiary chains (see Bernoulli, this volume) that it seems reasonable to imagine the same environmental conditions for the northwest Atlantic facies.

The basement topography is probably responsible for a differentiated sedimentation. On the top of the hills, carbonate oozes composed mainly of coccoliths, planktonic foraminifera, and some radiolarians were slowly deposited; while in the topographic depressions, the same components were mixed with clay minerals and elements of volcanic origin. Sediments from the hills were carried into the depressions by slumping and turbidity currents and are found only as clasts in the "basinal" sediments. These displacements and resedimentation might have been triggered by tectonic activity related to sea-floor spreading. The water depth of this environment is not easy to determine. Bernoulli (this volume) suggests that, at the time of deposition, the topographic highs were above the carbonate compensation depth, whereas the depressions were beneath it. This would explain the rarity of foraminifera in the "basinal" facies and their abundance in the clasts. It can also be proposed that the strongly different rates of sedimentation between the two facies could be responsible for an apparent concentration of the microfossils in the clasts. The faunal assemblages seem to indicate a probable upper bathyal environment (see Luterbacher, this volume).

The slight differences between the southern (Sites 99 and 100) and the northern areas (Site 105) appear closely related to basement features. At Site 105, the rough basement topography may be responsible for major slumps and abundant turbidites; evidence of volcanic activity also suggests the proximity of an active rift. At Sites 99 and 100, where the basement topography is smoother, displacements of sediments are less important and the lack of volcanic products suggests that that area was already out of the main active rifting zone when the red carbonate layers were deposited.

\section{THE TITHONIAN-NEOCOMIAN WHITE AND GRAY LIMESTONES}

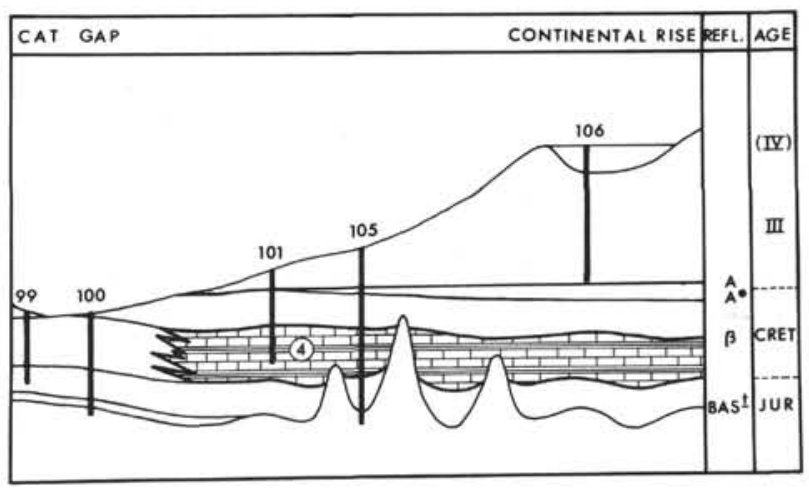

Overlying the red upper Jurassic limestones at Sites 101 and 105 are white to light gray limestones alternating with laminated dark-gray, soft, clayey limestones. This facies, dated Tithonian to Neocomian, seems to 
pass laterally, at Sites 99 and 100 , to calcareous oozes that may be interpreted as unlithified equivalents of these limestones.

The entire facies has been sampled at Site 105 (Cores 17 to 32 ); whereas at Site 101 only two cores (9A and $10 \mathrm{~A})$ were recovered from this interval. The facies will be described from the samples recovered at Site 105. The lower limit of the facies is in Core 32, which shows a rapid transition from the red clayey soft limestone to hard pale-pink to white limestone displaying large scale slump structures. The upper limit, in Core 17, grades into the overlying black clay formation and consists predominantly of a very clayey, finely-laminated, soft limestone which occurs more generally as intercalations in the white limestones throughout the facies. The top of these layers corresponds rather well to the Horizon $\beta$ of the seismic profiles (see Ewing and Hollister, this volume), and this observation should provide a means of determining the lateral extent of the facies. However, this cannot be done easily north of the approximate latitude of the New England seamounts as the high reflectivity of younger layers prevents a good definition of Horizons A and $\beta$. Nevertheless, the thickness of the sediments lying under Horizon A suggests that Horizon $\beta$ could still be present between the New England seamounts and the Newfoundland fracture zone. Toward the east, Horizon $\beta$ seems to disappear along the western edge of the Bermuda Rise. As is mentioned above, we believe that toward the south this formation grades laterally to calcareous oozes in the Cat Gap area. If the lithification process is due to, or is favored by, the overburden of more recent sediment, then the boundary between the limestone and the ooze should be close to the limit of the Horizon $\beta$ outcrop area. The formation probably extends under the continental rise, but because of the thickness of the Tertiary sediments, the deep reflectors and even Horizon A fade out rapidly and nothing is known of the relations between the deep-sea Mesozoic facies and their shelf equivalents.

\section{Sedimentary Structures}

The dominant feature of this facies is the alternation, sometimes very regular and almost cyclic, of two different lithologies:

1) White to pale gray limestone, with an occasional pale greenish hue, hard, almost homogeneous, with abundant burrows.

2) Dark greenish-gray, finely laminated, soft, clayey limestone. Laminations are generally about 1 millimeter thick; they are horizontal except in the slumped layers.

Generally the thickness of the beds for each of these two lithologic types varies from 5 to 25 centimeters in the regular cyclic zones. The white and pale-gray layers seem to be more abundant and thicker in the lower part of this interval, and the clayey laminated facies becomes progressively more and more important upward; it is largely predominant at the top of the formation, where it makes a transition to the more or less laminated, lower Cretaceous black clays.

Displacement of sediments and resedimentation resulted mainly in large slumped units (Figure 10); many of these are more than one meter thick. Some rare smallscale deformations were also observed but, unlike in the underlying formation, the limestones do not show any turbidite structures. Slump structures are sometimes difficult to observe owing to the small diameter of the cores; however, in many cases microdeformations of burrows and of layer boundaries provide good evidence for mass displacement of a whole bed. Most of the large-scale structures are found in the lower part of the formation. They disappear completely above Core 27 , and only occasional small-scale deformations are present above this level.

\section{Composition}

Two lithological types in this facies are distinguished by the composition of the sediments. The white homogeneous layers are dominantly recrystallized micritic calcite with common calcareous nannoplankton; clay minerals and terrigenous detritus are almost absent. The dark, laminated beds consist of abundant clay minerals and calcareous nannoplankton, usually with much organic matter; recrystallized micritic calcite is very rare. Pyrite also is regularly present in the laminated layers, either as small spherules and framboids (raspberry-like groups or spherules) or as a diagenetic replacement of radiolarians. In Core 17 it occurs as a small, well-crystallized layer 2 centimeters thick (Figure 12); some other centimeter-thick concentrations were found in several cores.

X-ray mineralogy indicates the presence of abundant montmorillonite with some mica and occasionally abundant zeolites at Site 105, whereas at Site 101, in the south, zeolites are absent. Another difference between these two areas is in the carbonate composition. At Site 101 several layers of the last core (10A) contain abundant dolomite which is absent at Site 105. Siderite is very rare at both sites in this interval.

Megafossils (aptychi) were found only at Site 105 .

\section{Lithification and Diagenesis}

The two types of sediments in this facies differ in degree of lithification. The massive white and pale gray homogeneous layers are dominantly micritic limestones, showing abundant recrystallization of the calcite and lesser amounts of calcareous nannoplankton. The cementation of these rocks is probably the result of pore-filling reprecipitation of the calcite after local dissolution of some or most of the calcareous 


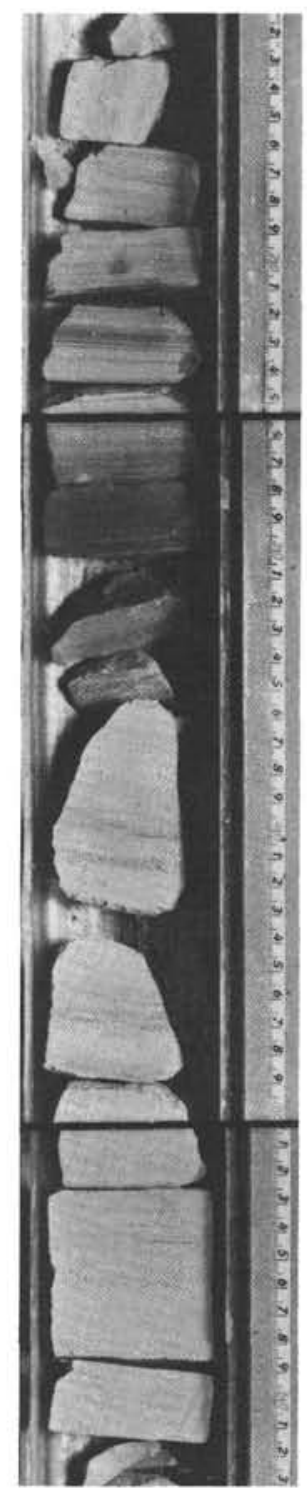

101A-9-1

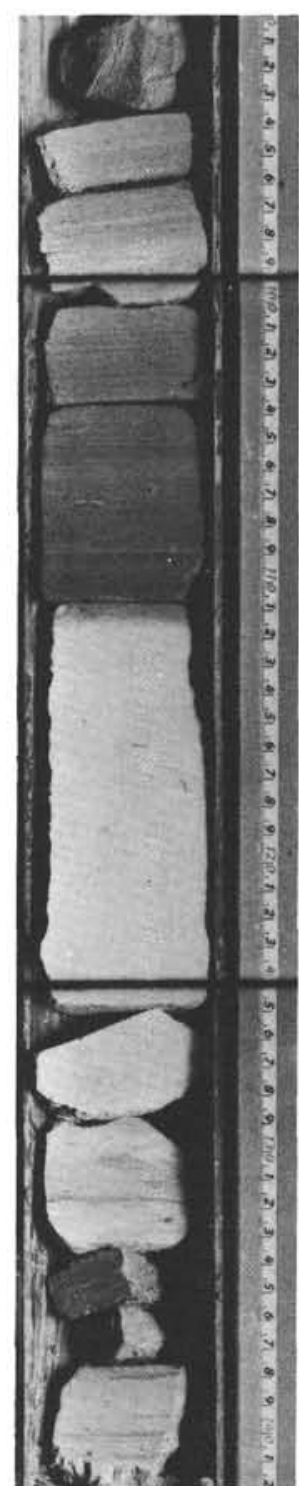

$105-26-1$

Figure 11. Comparison of the lower Cretaceous white and gray limestones recovered from Sites 101 and 105 (distance between sites is approximately 630 nautical miles).

microfossils. In contrast, the laminated layers are much softer and show only poor cementation. They contain only rare or no recrystallized micritic calcite, and the nannoplankton-and even some rare foraminiferaappear well preserved. As has been observed in the underlying facies, the lack of cementation is related to the clay content of the sediment; the clay minerals prevent the minimum circulation required for the reprecipitation of calcite in inter-granular spaces.

Other diagenetic processes include dolomitization (and very rare occasional sideritization) in some of the lightcolored carbonate-rich layers at Site 101, and pyritization in the clay-rich laminated dark layers at both sites.
Pyrite is clearly related to a reducing environment, as it is found mainly in the layers rich in organic matter.

\section{Discussion}

The white and gray limestone facies, with its typical alternations of homogeneous and laminated layers marks the end of the dominant carbonate facies in the deepening North American basin. The lower part of the facies, with its large slumped complexes, may be regarded as resulting from the continuation of the topographic conditions that prevailed during the deposition of the red limestones; the pure carbonate facies similar to that present on the top of the basement 


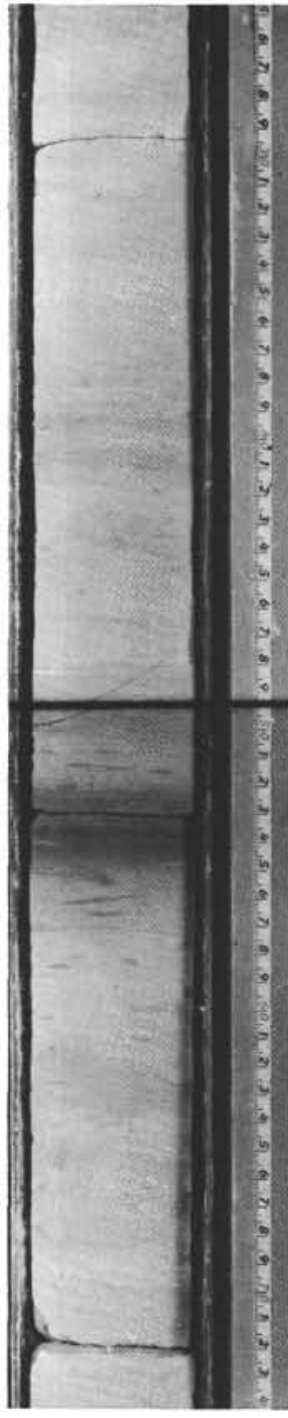

105-28-3

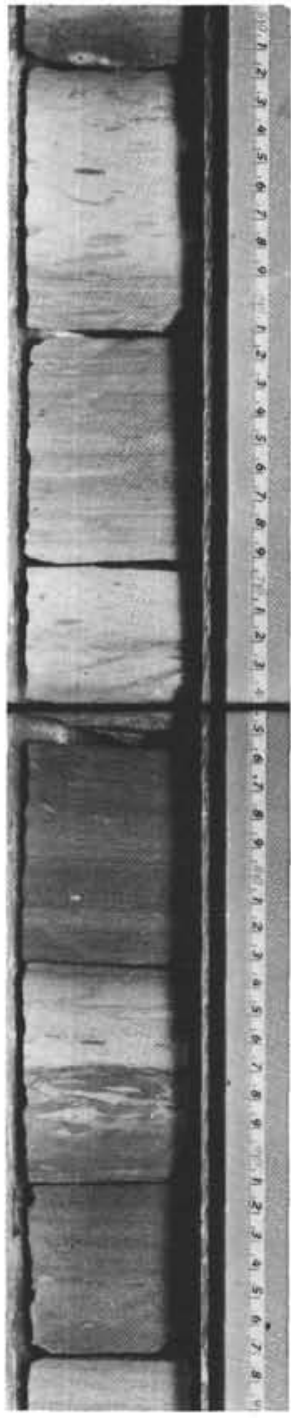

$105-18-4$

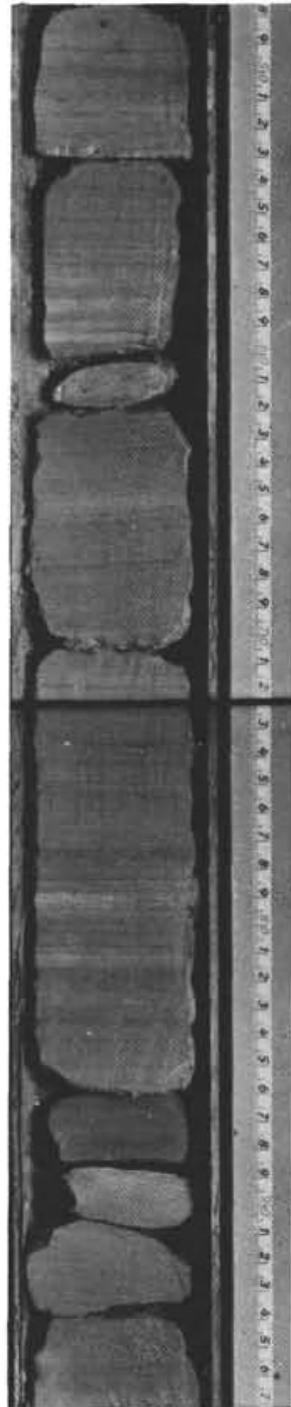

$105-17-2$

Figure 12. Evolution of the sedimentary environment during the Early Cretaceous at Site 105. The increasing abundance of dark, finely laminated layers rich in organic matter toward the upper parts of this interval corresponds to the predominance of stagnant condition. Core 17 shows the transition to the overlying black clay facies. Note the large nodule of well-crystallized pyrite at 60-62 cm in 105-17-2.

elevations is here predominant. The disappearance of slump structures toward the upper parts of the facies may be interpreted as the end of the depression-filling sedimentation, and the facies passes gradually to more or less cyclic alternation of 1) carbonate oozes containing much evidence of benthic life, which indicate well oxygenated bottom conditions, and 2) sediments rich in organic matter deposited in thin, submillimeter laminae, which indicate almost stagnant and reducing conditions.
Stagnant conditions occurred more often as time progressed and dark laminae are dominant in the upper part of the formation. At the end of this interval the bottom of the basin was probably relatively flat, and the current circulation had almost completely stopped. The water depth of this basin cannot be determined with precision, but paleontological determinations indicate a continuous deepening throughout the section. Most of the sediments can be considered as deep bathyal but probably not abyssal (Luterbacher, this volume). 


\section{THE TITHONIAN-NEOCOMIAN CARBONATE OOZES AND CHALKS OF THE CAT GAP AREA}

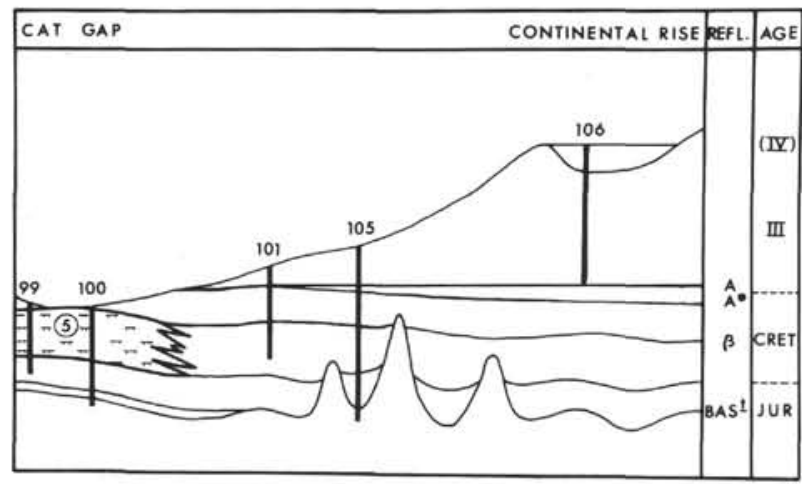

The two holes drilled in the Cat Gap area (99A and $100)$ recovered soft to poorly lithified carbonate sediments overlying the red clayey Oxfordian-Kimmeridgian limestones. At Site 99 the TithonianNeocomian section consists mainly of ooze and chalk with abundant chert. At Site 100 only one core (Core 1) was recovered in this section after 203 meters of drilling. This core, situated relatively close to the top of the Oxfordian-Kimmeridgian limestones consists of relatively pure, soft, nannoplankton ooze with common chert nodules. Similar facies of the same age were recovered in the area during Leg 1 at Sites 4 and 5 (Ewing et al., 1969).

\section{Sedimentary Structures}

At Site 99 the recovery was rather poor, and most of the cores were badly disturbed. Most of the sediments (both ooze and chalk) look homogeneous and are generally white to very pale gray except for some rare faint, grayish bedding or banding caused by increases in clay content. At Site 100, where core disturbance was less important, the sediments are homogeneous soft white ooze, with rare faint light greenish-gray bands. Chert nodules, brown to pale gray, were found at both locations. These usually show indistinct bedding planes (see Site Reports).

\section{Composition, Lithification, and Diagenesis}

The sediments are composed mostly of calcium carbonate and occasional chert. At Site 100, where lithification is very poor, the ooze consists mainly of coccoliths and some foraminifera. Recrystallized micritic calcite was found in the more indurated zones. At Site 99 , where the section seems to contain abundant chalk and perhaps even some occasional limestones, the composition of the sediments is largely dominated by recrystallized micritic calcite. Foraminifera are absent, as in the limestones of the same age recovered at Sites 101 and 105. This absence suggests that most of the foraminifera have been dissolved and were the source for the recrystallized micritic calcite.

Chert nodules, and small fragments probably broken during drilling operations, consist mainly of quartz or chalcedony and some disordered cristobalite; they contain ghosts of nannoplankton and radiolarians.

\section{Discussion}

These sediments have been sparsely sampled, and any conclusions about this facies can only be tentative. However, comparison with the results from Leg 1 (Sites 4 and 5), where comparable sediments were recovered in the same stratigraphic interval, enable us to assume that this section consists of poorly lithified or unlithified carbonate sediments that may correspond to the Tithonian-Neocomian limestones described previously. If we consider that strong currents may have prevented any significant deposition of sediments in the Cat Gap area since the late Cretaceous (see Ewing and Hollister, this volume), the poor state of lithification of these sediments may be the result of the lack of a sufficiently thick overburden. Pressure, temperature, and factors such as circulation and composition of interstitial fluids probably determine the cementation of the carbonate oozes.

\section{THE LOWER CRETACEOUS BLACK CLAYS}

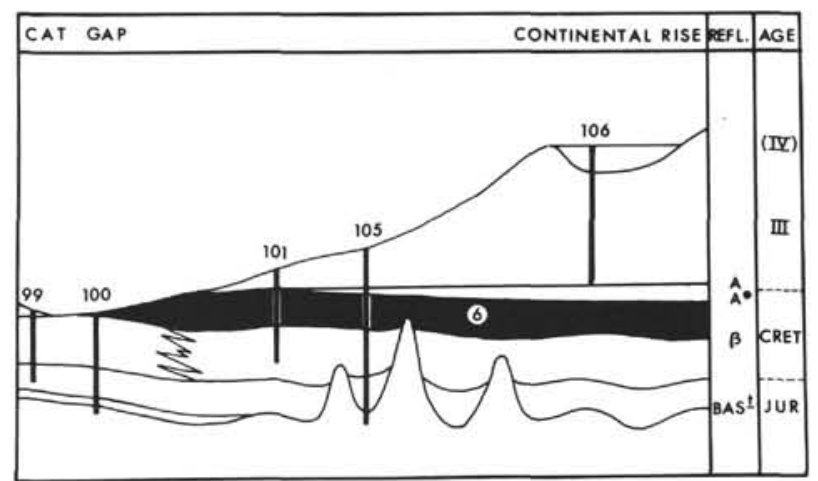

Black and dark green carbonaceous clays and shales were sampled at Sites 101 and 105 (Figure 20). The base of this facies is dated late Neocomian (late Valanginian to early Barremian). The contact with the underlying 
limestones may be represented at the top of Core 17 of Site 105 by a black clay layer 2 centimeters thick that overlies light-gray limestone (see Site Reports). The sediments recovered in Core 17 subjacent to this contact show a gradation from clayey carbonaceous soft limestones (Core 17) to more carbonaceous clays. This gradation is believed to correspond to Horizon $\beta$. The upper limit of the black clay facies was sampled only at Site 105, where the contact between this facies and undated clays was observed. This upper boundary, dated early Cenomanian, is believed to correspond to Horizon $\mathrm{A}^{*}$ (see Ewing and Hollister, this volume). At Site 101, the youngest age obtained in the black clays is only Albian, and at this site the upper limit of the formation corresponds to a single Horizon A. The presence of the reflectors corresponding to Horizons A and $\mathrm{A}^{*}$ on many seismic profiles suggests a wide distribution for this facies. Results from sites drilled during Leg 14 lend additional support to this idea. Carbonaceous sediments have been recovered in the same stratigraphic position at Sites 135, 137, and 138 in the eastern Atlantic basin, and at Site 144 in the western basin (Hayes et al., 1971). The black clay formation may represent most of the interval between Horizons $\beta$ and $\mathrm{A}$ in the North American basin east of the Bermuda Rise.

In the Cat Gap area, where both Horizons $A$ and $\beta$ crop out, evidence of possible outcrops of the black clay has been obtained in piston cores recovered by ships of the Lamont-Doherty Geological Observatory (Windisch et al., 1968; Habib, 1970) although some of these cores may have sampled reworked sediments. The cores obtained by drilling during Leg 1, Site 4, (Ewing et al., 1969) also contain coarse carbonate detrital elements embedded in a black carbonaceous matrix of Albian to Cenomanian age. At Site 101, the top part of the facies is missing and has probably been subject to considerable erosion.

\section{Sedimentary Structures}

The dominant characteristic of this facies is of very dark, (black to dark greenish gray) stiff clays with abundant thin silty laminae (Figure 13). These laminae are dominantly light gray (zeolitic and sideritic silt) and occasionally dark brown (pyrite silt) or white (disordered cristobalite and montmorillonite). Some hard layers of siderite (see also Figure 14) may reach a thickness of 0.5 centimeter. The lower part of the section shows very dark sediments with very thin discrete laminations. In the upper half the laminae become thicker and more abundant, and gradually alternations of black and dark olive green layers become predominant. The dark green beds contain burrows, appearing as black zones in the green matrix, and abundant white to pale gray streaks, lenses, and layers (zeolitic silt). The almost cyclic repetition of these layers is very similar to that observed in the underlying white and gray limestones (see for example Figure 13) and may account for the same kind of environment, namely alternation of strongly reducing and mildly oxidizing conditions. This repetition would indicate that the stagnation has been interrupted by periods of slow bottom-current circulation allowing the persistence of some benthic life which is attested to by the burrows. The top of the facies shows a large increase in the abundance of green intervals. These intervals are lighter in color and are more homogeneous than those from the underlying layers, and the contacts between the black and green layers become very sharp.

\section{Composition}

At Site 105 the dominant components of this formation are clay minerals, organic matter, and zeolites. Minor constituents are carbonates, quartz, feldspars, and pyrite. The main differences observed in the cores from the same interval at Site 101 are the absence or extreme rarity of zeolites, and much higher values of the terrigenous clay minerals/montmorillonite ratio. These differences suggest, as in the underlying sediments, a less important contribution from the volcanism in the southern area of the basin.

\section{Clay Minerals}

At Site 105, in the bulk samples, the major clay mineral appears to be mica which averages about 40 per cent of the crystallized fraction (the amorphous fraction represents about 50 to 60 per cent of the sediment). Montmorillonite content varies from 10 to 25 per cent; chlorite and kaolinite are rare ( 0 to 2 per cent). The less than 2 micron fraction shows a different pattern, with montmorillonite dominant. At Site 101, detrital clay minerals are predominant both in the bulk samples and in the less than 2 microns fraction. However, the base of the section (Hole 101A, Core 8) contains a significant amount of montmorillonite.

\section{Organic Matter}

The total organic carbon content, as determined on 34 samples from this part of the section, shows several values around 3 per cent. One value from Core 9 of Site 105 reaches 14.8 per cent. Concentration of carbon was high enough so that one sample could be burned aboard the ship. Detailed analyses of the organic matter from these carbonaceous clays are published elsewhere in this volume (Simoneit et al.); they indicate relatively low contribution from plant-derived organic debris.

\section{Zeolites}

Clinoptilolite (Figure 15) is abundant in all the cores from this interval at Site 105 , and is absent or very rare at Site 101. Generally it is concentrated in numerous white to gray, thin, silty layers, and is also scattered in the sediments throughout the section. The amount of 
clinoptilolite varies from 20 to 33 per cent of the crystallized fraction of the bulk samples from Cores 11 to 16 .

\section{Carbonates}

The carbonate content of these clays is generally low and in many places nil. The carbonate fraction, represented by some calcareous nannoplankton and siderite, is present only in the middle part of the sequence at Site 105 (Cores 11 to 13). At Site 101, siderite is common throughout the interval. At both sites, this mineral was found either in small gray nodules and silty lenses and layers or as isolated rhombs scattered in the sediment (Figure 14).

\section{Quartz and Feldspar}

These constituents are regularly present in minor concentration in almost all the samples. Feldspars are mainly plagioclase. They are generally scattered in the sediments but are found occasionally concentrated in small white spots and streaks that resemble burrow fillings. Similar structures were found also in the Tertiary hemipelagic muds at Sites 102, 103, and 104, and seem then directly associated to a reducing environment. Their origin is still unexplained.

\section{Pyrite}

This mineral occurs mainly in thin silt layers as wellcrystallized small cubes and spherules. It is sometimes observed as a replacement of rare radiolarian debris or as small spherules and fragments scattered in the sediments.

\section{Lithification and Diagenesis}

The sediments of this section are unlithified or poorly lithified and consist of stiff but plastic clay, sometimes with an apparent fissility caused by the presence of numerous thin silty layers. The only hard, cemented material is found in small siderite nodules and thin layers.

The most important diagenetic processes appear to have been the formation of authigenic siderite and pyrite. Both minerals are indicative of a reducing environment and probably reflect the stagnant conditions that prevailed during the deposition of these sediments.

\section{Discussion}

Stagnation in the whole North American basin, and probably in the deepest parts of the entire North Atlantic characterized most of the Early Cretaceous. This stagnation was accompanied by subsidence. The water depth is again difficult to determine; the lack of calcareous microfossils was caused either by the depth increasing beyond the carbonate compensation depth, or by dissolution resulting from high $p \mathrm{H}$ of the interstitial water in this particular environment. Carbonaceous shales and clays do not indicate water-depth inasmuch as they may occur, with the same composition, in any physiographic realm from shelf depressions to abyssal basins. However, it seems reasonable to assume that they represent here a deep environment, deep bathyal to abyssal, if one supposes that the general subsidence of the area was continuous from the deep bathyal Tithonian-Neocomian limestones, where the stagnation was already intermittent, to the overlying deep-sea barren brown clays. The general subsidence of the continental shelf during this interval is shown by the thick lower Cretaceous shelf sediments which consist of shallow water fluvio-marine to lagoonal facies (Kraft and Maisano, 1968). These deposits, containing mainly shales and sands, show that terrigenous detritus was delivered to the ocean during this time interval. Fine-grained and relatively rare terrigenous components in the black clay facies suggests that a barrier (reef system) or a trap (trough) in the rise or slope area prevented the transport of coarse terrigenous material to the deep basin. Contributions of volcanic material increased in the northern area but were less intense in the south.

The end of the stagnation is reflected in the top part of the facies where some intermittent current circulation may have been responsible for the deposition of some layers of "normal" deep sea brown clay in the lower part of Core 9 and in Core 10 at Site 105 (105-10-1). This brown clay may indicate the beginning of some bottom current circulation in the latest Albian or earliest Cenomanian. In the southern part of the basin a strong current circulation may have begun at about the same time, eroding the upper part of the black clay at Site 101 and most of it in the Cat Gap area, and reworking the Cretaceous sediments recovered at Sites 4 and 5 (Leg 1).

\section{THE UPPER CRETACEOUS TO LOWER TERTIARY(?) MULTICOLORED CLAYS}

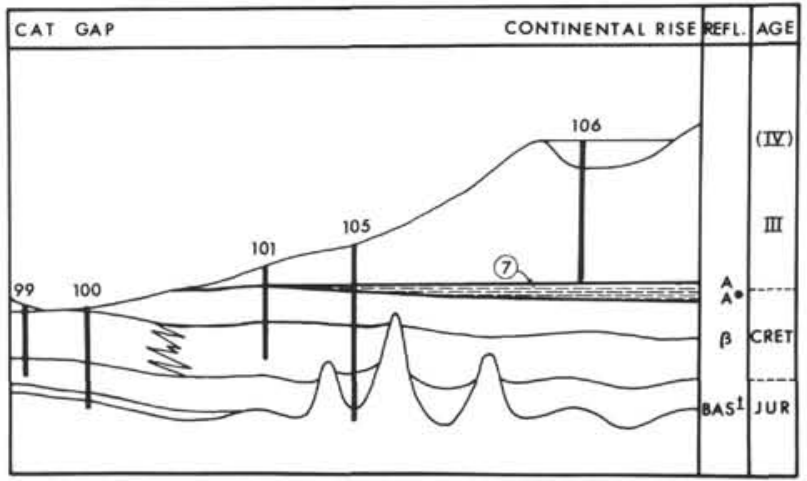




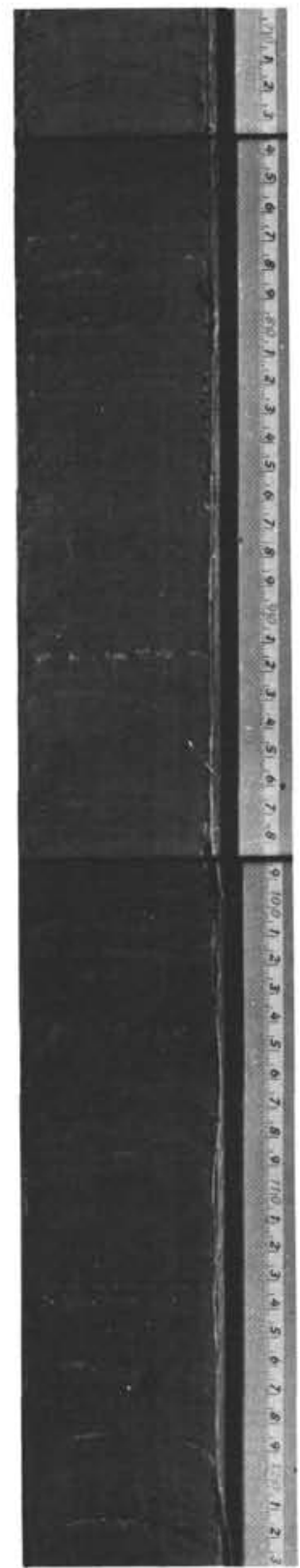

105.15-6
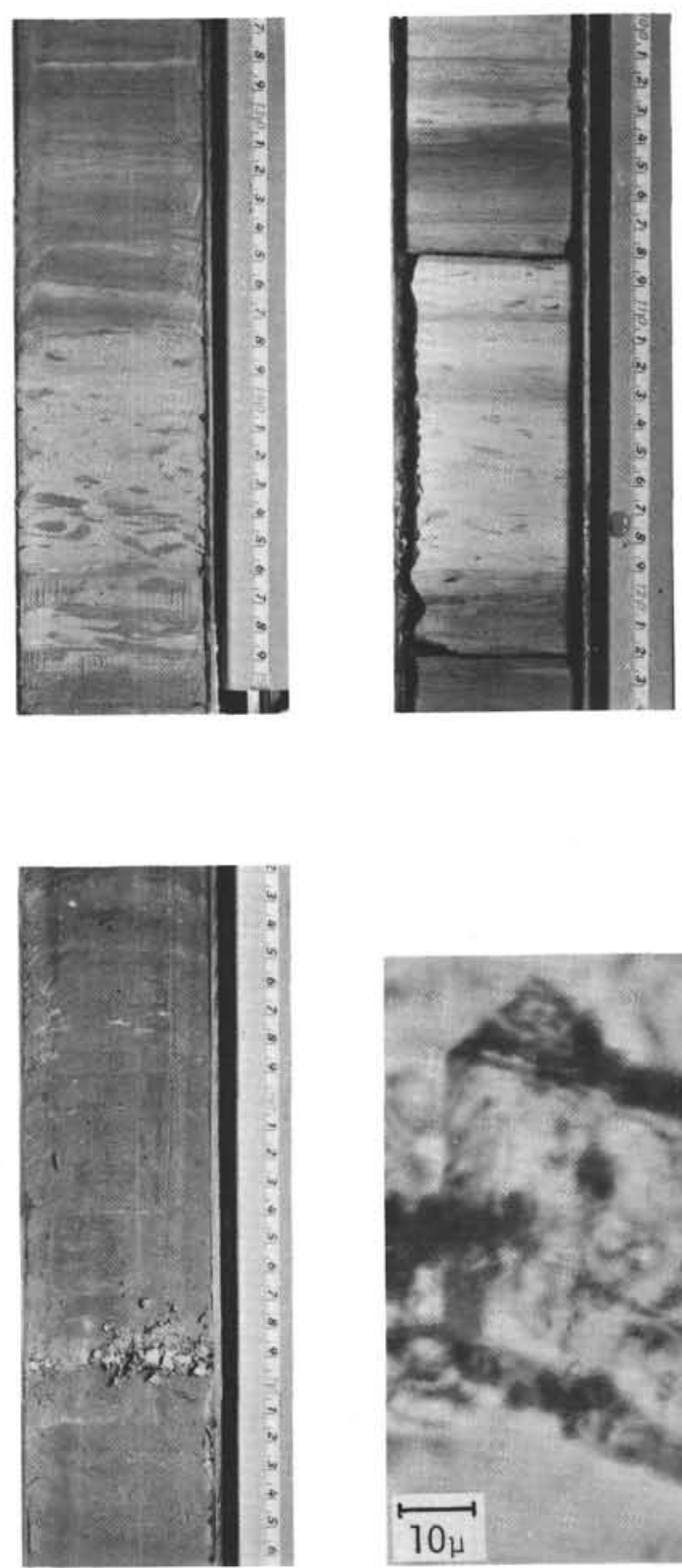

$105-15-2$

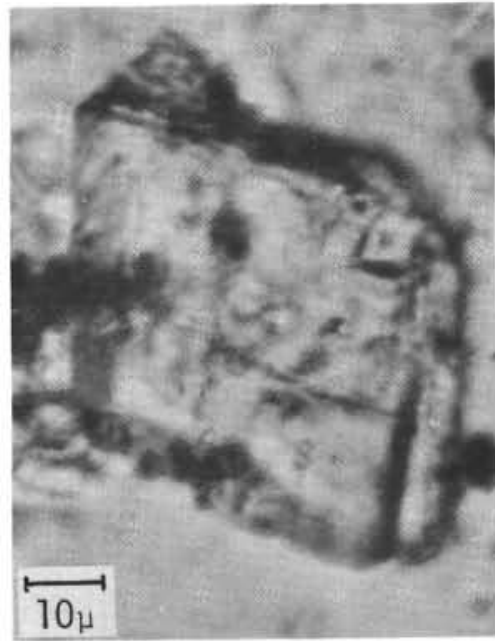

105-15-Core Catcher

Figure 13. Different aspects of the lower Cretaceous black clay.

Sample 105-15-6 (left) shows the most common facies of this sequence: black carbonaceous clay with numerous thin light gray laminae of zeolites (see, for example, at 91,113, 114, 119 $\mathrm{cm}$ ) and some dark, barely visible laminae of pyrite (see, for example, at 70, 80, 81, 99.5, $101.5,102.5 \mathrm{~cm})$.

Sample 105-15-2 (lower center) shows concentration of hard siderite; see also the photomicrograph of a siderite rhomb from Sample 105-15, core catcher at lower right.

Sample 105-11-2 (upper center): alternations of finely-laminated black carbonaceous clay and green layers with burrows; compare with the alternations in the underlying limestones in 105-28-1 (upper right). 

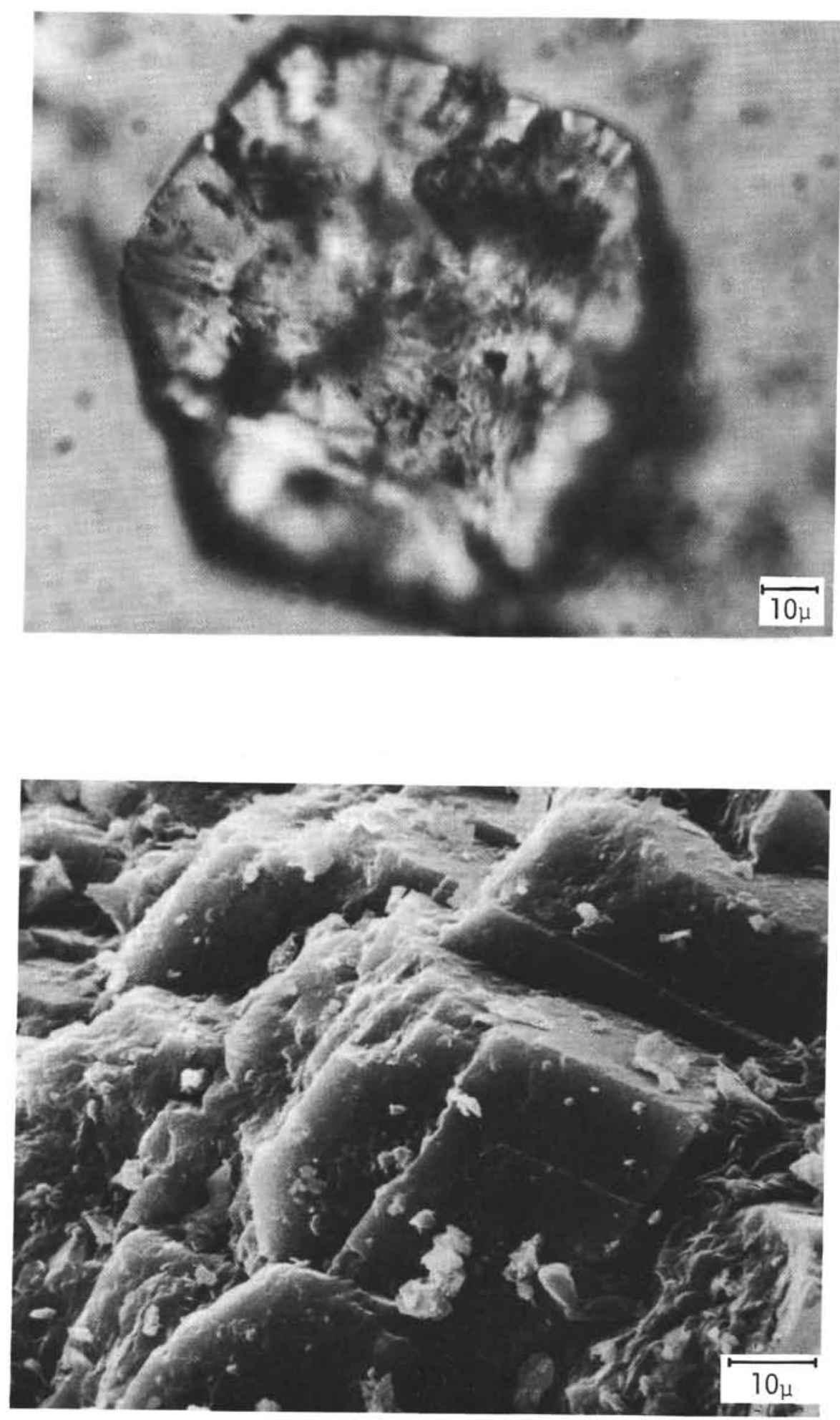

Figure 14. Large siderite rhombs from Samples 105-15, core catcher (photomicrograph-upper) and 101A-6-1, $76 \mathrm{~cm}$ (scanning electron micrographlower). 


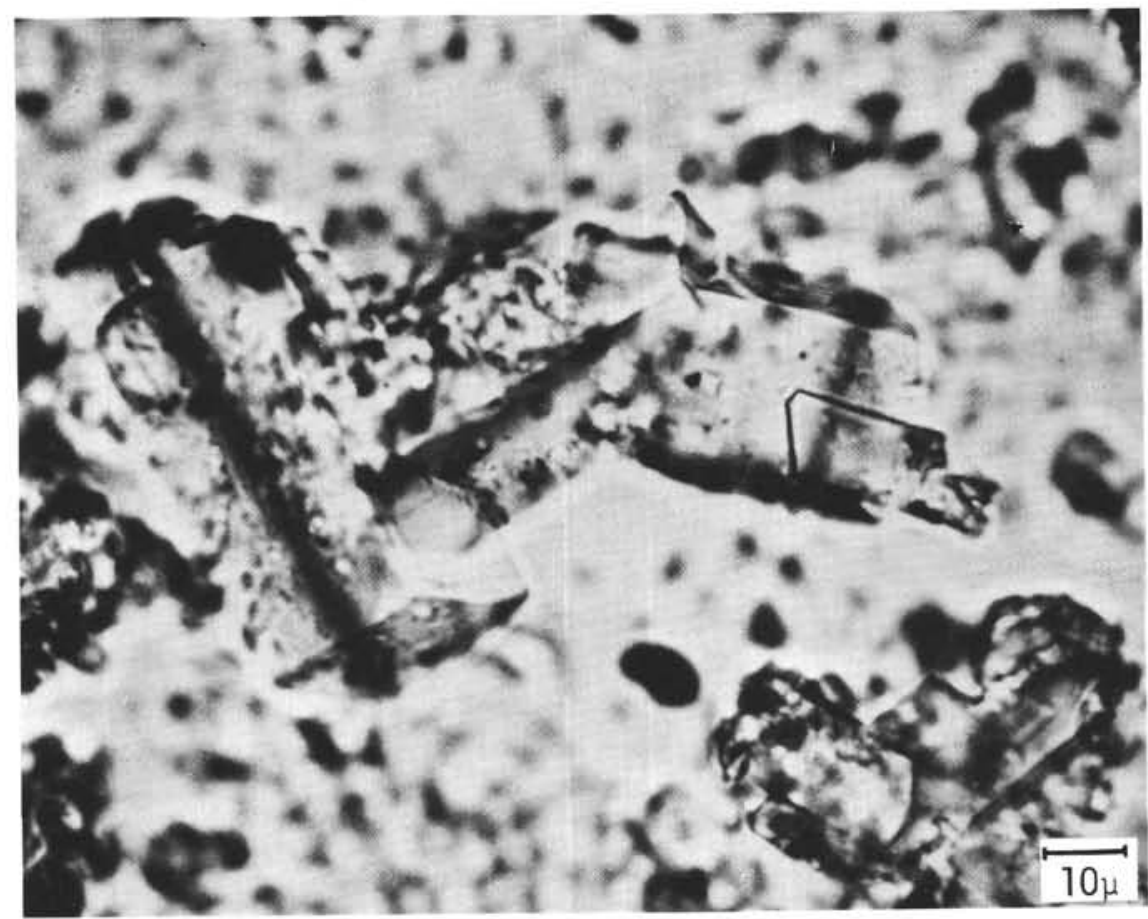

A

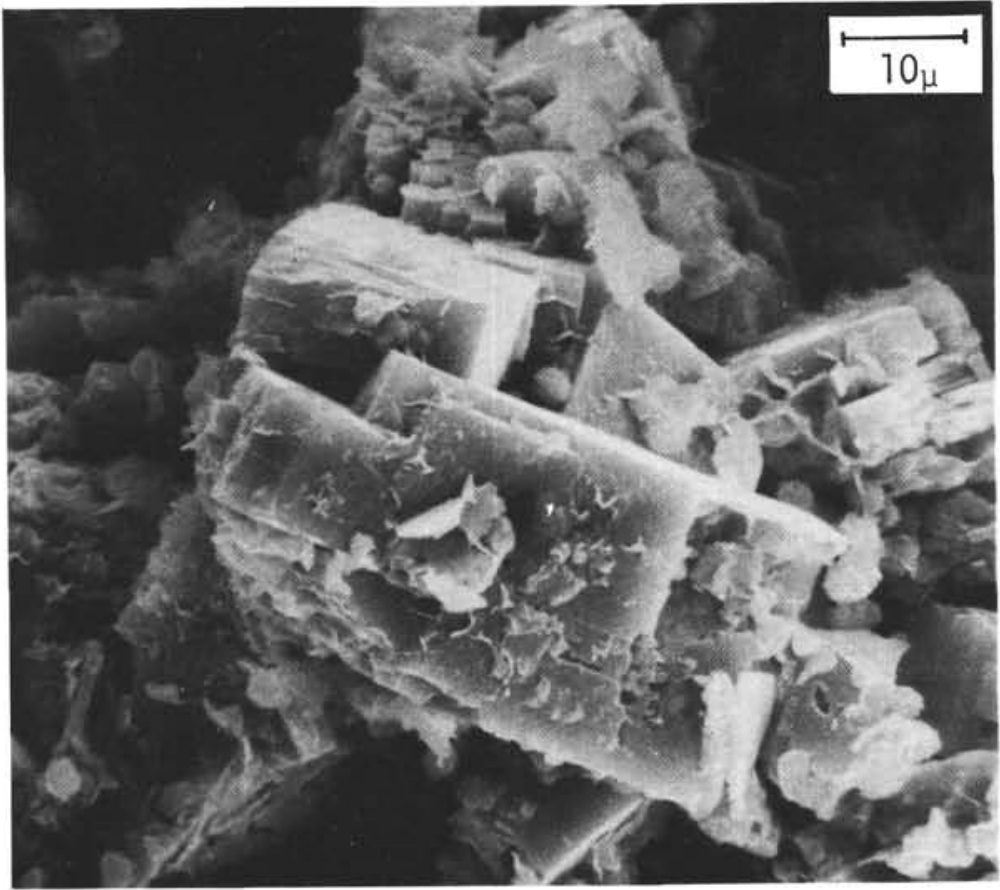

B

Figure 15. A. Photomicrograph showing interpenetration of clinoptilolite crystals in Sample 105-13, core catcher (plane polarized light).

$B$. Scanning electron micrograph of clinoptilolite crystals from the same sample. 
At Site 105 (Cores 5 to 9), an interval of multicolored clays about 50 meters thick was recovered above the black and green carbonaceous clays. Much of this material contains thin layers of white, yellow, orange, pink, reddish-brown, black, purplish, and pale green clay in a dominantly pale brown to yellowish-brown clay. The sediment is barren of fossils but comparison with the lower parts of Holes 7 and 9 (Legs 1 and 2) suggests a late Cretaceous to early Tertiary age. The upper part of the interval may be Eocene (on the basis of dinoflagellates; see Habib, this volume). A marked change in drilling rate just above the first core in this interval supports our assumption that Horizon A is slightly above Core 5 . If the lower boundary of the multicolored zone corresponds to Horizon $\mathrm{A}^{*}$, then this facies would correspond to the "double" Horizon A observed on several seismic profiles from the North American basin (see Ewing and Hollister, this volume).

\section{Sedimentary Structures and Composition}

The most striking characteristic of sediment from this zone is the alternation of bands or thin beds of random thickness showing the brilliant colors mentioned above. Some intervals show distinct mottling of yellowish to pink material in a dusky-brown matrix. The thickness of the beds ranges from about 0.1 centimeter to 100 centimeters. Patches and specks of black crumbly matter are present throughout; near the top of Core 5 their size reaches several centimeters. The beds owe their color variation largely to variable amounts of goethite associated with montmorillonitic and micaceous clay. Hematite is a relatively minor component. The lower part of the multicolored zone contains appreciable amounts of pyrite and clinoptilolite. Sphalerite, accompanied by pyrite (Figure 16), occurs in silty zones that have the general appearance of burrow fillings. It seems doubtful that these represent actual burrows of animal origin, inasmuch as other evidences of organic activity are absent. An analysis of a representative sample of a band near the base of the multicolored zone containing such silty spots showed 3.6 per cent zinc (Frank Manheim, analyst, March, 1971). The sphalerite content of a silty spot in this zone is about 50 per cent. The general zinc content of the multicolored zone ranges from about $50 \mathrm{ppm}$ to about $300 \mathrm{ppm}$ (Table 2), with a mean of $145 \mathrm{ppm}$. Black or very dark brown zones and specks are composed of iron and manganese oxides. One such manganese-rich zone in Core 5, Section 1, gave a goethitetype structure (groutite?) by X-ray diffraction. A black nodule from the core catcher of Core 7 gave the structure of todorokite, a hydrated manganese oxide. The overall manganese oxide content of the multicolored zone ranges from 0.01 per cent to 3.14 per cent manganese oxide (Table 1 ) with a mean of 0.28 per cent.

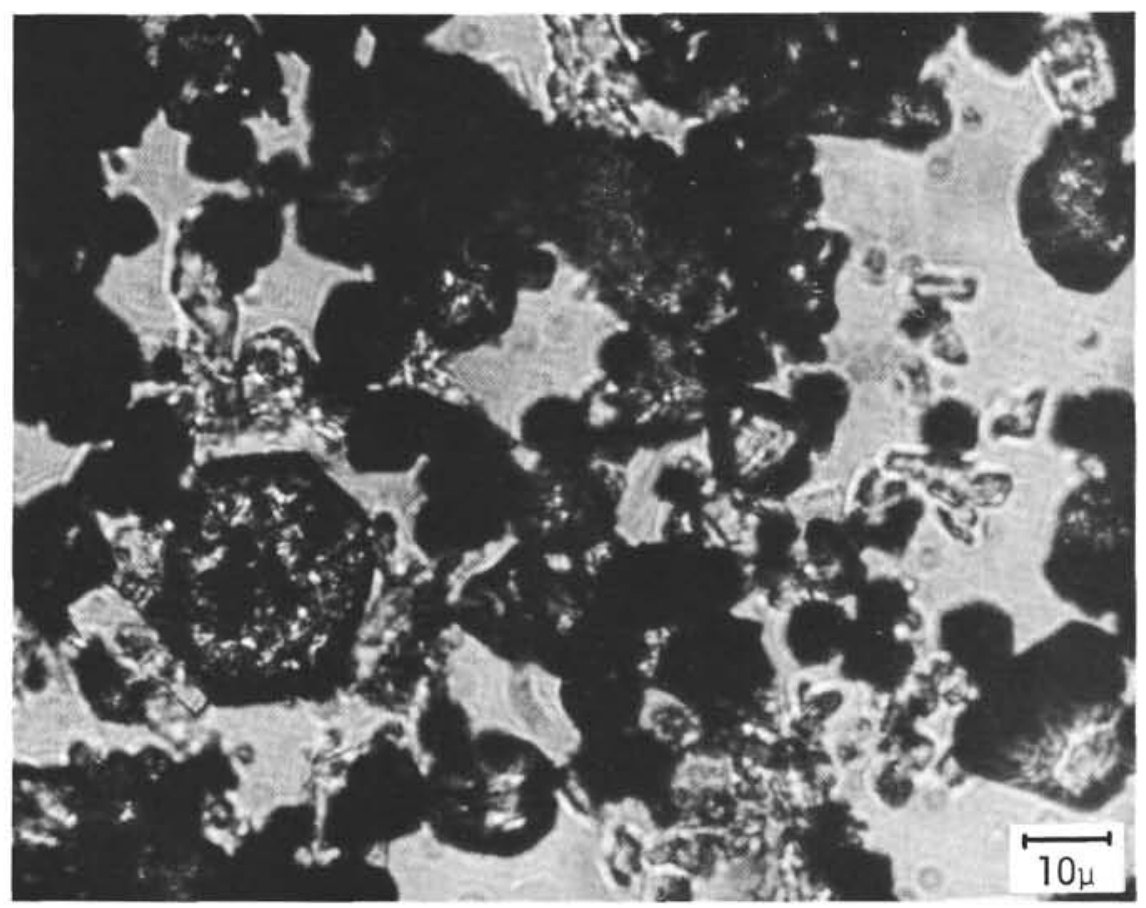

Figure 16. Sphalerite - photomicrograph of silty spot from Sample 105-9-3, 117 $\mathrm{cm}$ showing triangular and hexagonal grains of sphalerite, black grains of pyrite and elongate transparent laths of clinoptilolite. 


\section{Comparison with Hot Brine Deposits of the Red Sea}

The colorfully banded characteristics of the zone and the occurrence of goethite-rich bands invite comparison of these materials with the multicolored banded deposits associated with hot brines in the Red Sea (Degens and Ross, 1969). On a qualitative basis, the mineralogy of the materials from Hole 105 is similar to that of the Red Sea deposits in several respects. A comparison of this hole with the Red Sea mineralogy is shown in Table 3. The minerals common to both areas are underlined in the table. The prominence of minerals such as sphalerite and goethite led us to consider the possibility of some relationship between the origins of the two types of sediment. The chemical compositions of the sediments of the two areas differ considerably, however, as shown in Figures 17 and 18 . Although the range of values for the Red Sea hot brine deposits is especially large, the means for the various elements illustrate the contrasts between the two groups. Elements that are more abundant in the multicolored zone of Hole 105, together with the factor by which they exceed the mean values for the Red Sea materials are as follows: $\mathrm{Si}, 2.8 \mathrm{X} ; \mathrm{Al}, 6.8 \mathrm{X} ; \mathrm{Mg}, 1.7 \mathrm{X}$; $\mathrm{K}, 5.2 \mathrm{X} ; \mathrm{Cr}, 2.9 \mathrm{X} ; \mathrm{Ni}, 8.9 \mathrm{X} ; \mathrm{V}, 25 \mathrm{X}$. Those elements that are more abundant in the Red Sea deposits, together with the factors by which they exceed the values for the materials from Hole 105 are as follows: Fe, 5.9X; Ca, 11.1X; Mn, 5.9X; $\mathrm{Zn}, 25 \mathrm{X} ; \mathrm{Cu}, 60 \mathrm{X} ; \mathrm{Pb}$, 26X; Sr, 4.9X.

The considerably larger amounts of $\mathrm{Al}_{2} \mathrm{O}_{3}$ and $\mathrm{K}_{2} \mathrm{O}$ in the materials from Hole 105 are due to the abundance of kaolinite and mica, minerals that are virtually absent from the Red Sea deposits. Small amounts of chlorite probably account for the larger content of magnesium.

Large concentrations of goethite, hematite, manganese oxides, pyrite, sphalerite, and chalcopyrite in the Red Sea deposits account for the greater abundance of iron, manganese, zinc, copper, and lead. Although all these minerals but chalcopyrite occur in the multicolored sediments from Hole 105, their concentrations are too small to raise the overall content much above background levels for marine sediments. Calcium and strontium are more abundant in the Red Sea deposits, probably because of the occurrence of carbonates and anhydrite, which are lacking in Hole 105 . We have not attempted to account for the differences in the nickel and vanadium.

Further differences between the two localities are the absence at 105 of any indication of associated brines, and the fact that the location of Site 105 is far from any possible active rift at the time that the multicolored sediments were deposited.

Goethite-rich and manganese oxide-rich bands and spots of sphalerite do occur, however, and some explanation of their origin is needed. Bostrom and Peterson (1966), Bostrom et al., (1969), von der Borch and Rex (1970) and von der Borch, Nesteroff and Galehouse (1971) have proposed that iron and manganese oxides are precipitated on the flanks of midocean rift areas from hydrothermal exhalations associated with volcanic activity in the rift zone. The effects of such exhalations may extend long distances from a rift and precipitation of the oxides may occur far from an active ridge. Low production rates and slow accumulation of terrigenous detrital clays would prevent the oxides from being lost by dilution among the normal sediments, and yet the introduction of detrital clays would still dilute the precipitates to the point that no remarkably rich concentrations such as those in the Red Sea deposits could form. Zinc ions introduced by these exhalations probably required local sulfide ion concentrations in order to precipitate as sphalerite, and this may explain the occurrence of sphalerite associated with pyrite in burrow-like fillings. Variations in the ratio of exhalation material and terrigenous detrital material arriving in the area as time progressed resulted in the deposition of the varicolored bands.

\section{THE TERTIARY DEPOSITS}

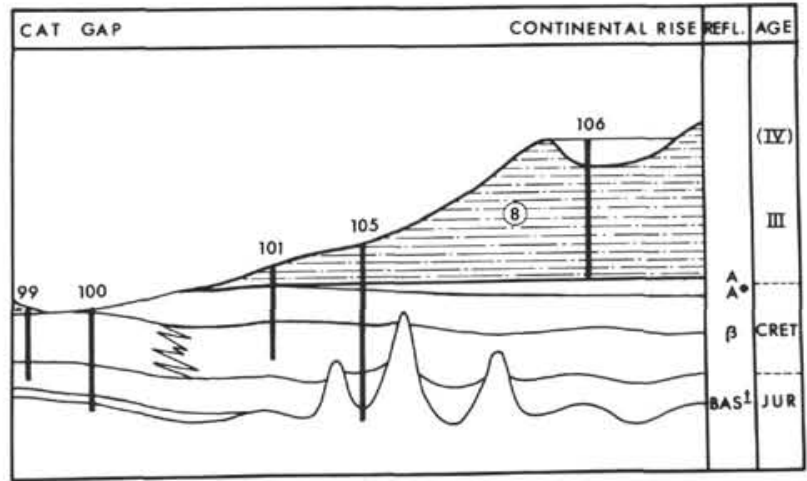

Greenish-gray hemipelagic silty clay of late Tertiary age was recovered above a major hiatus, which occurs on top of the lower Cretaceous black clays, at Sites 101 and 105 and in all cores taken at Sites 102, 103, 104 and 106. This material is recorded on seismic reflection profiles as homogeneous, unstratified, acoustically transparent deposits. A few meters of Miocene and Pliocene calcareous ooze were recovered from the top of Hole 99, and approximately 8 meters of compact calcareous-siliceous ooze devoid of terrigenous debris was recovered from Hole 108. A total of 8 meters of Eocene, 1 meter of Oligocene, 149 meters of Miocene, and 75 meters of Pliocene sediments were recovered on 


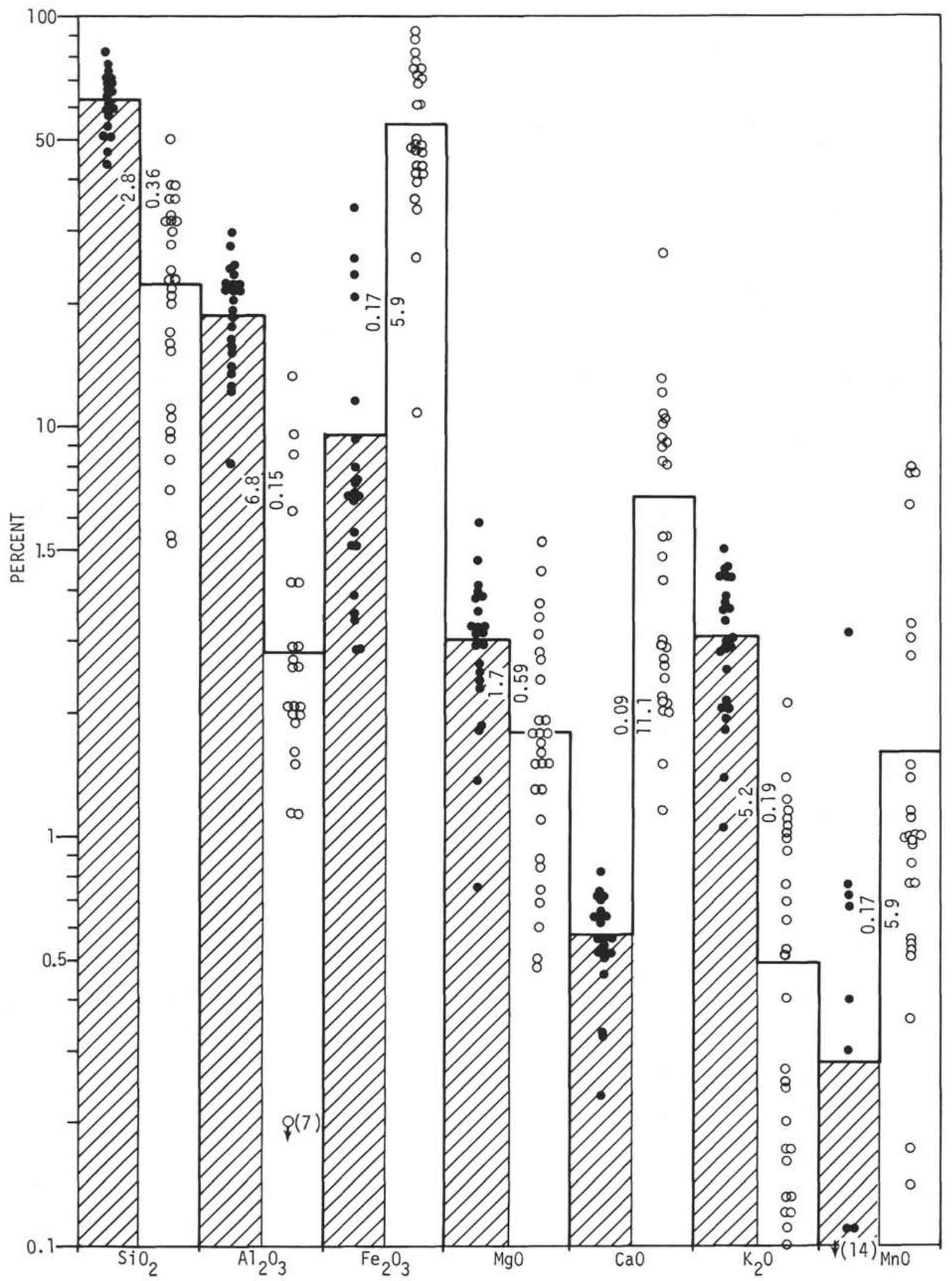

Figure 17. Comparison between major elements (as oxides) contents (ignited sample basis) of the multicolored sediments of Hole 105 and the hot brine deposits of the Red Sea. Solid dots are Hole 105 data; open circles are Red Sea data (Bischoff, 1969). Horizontal bars are means; numbers are difference factors between means. 


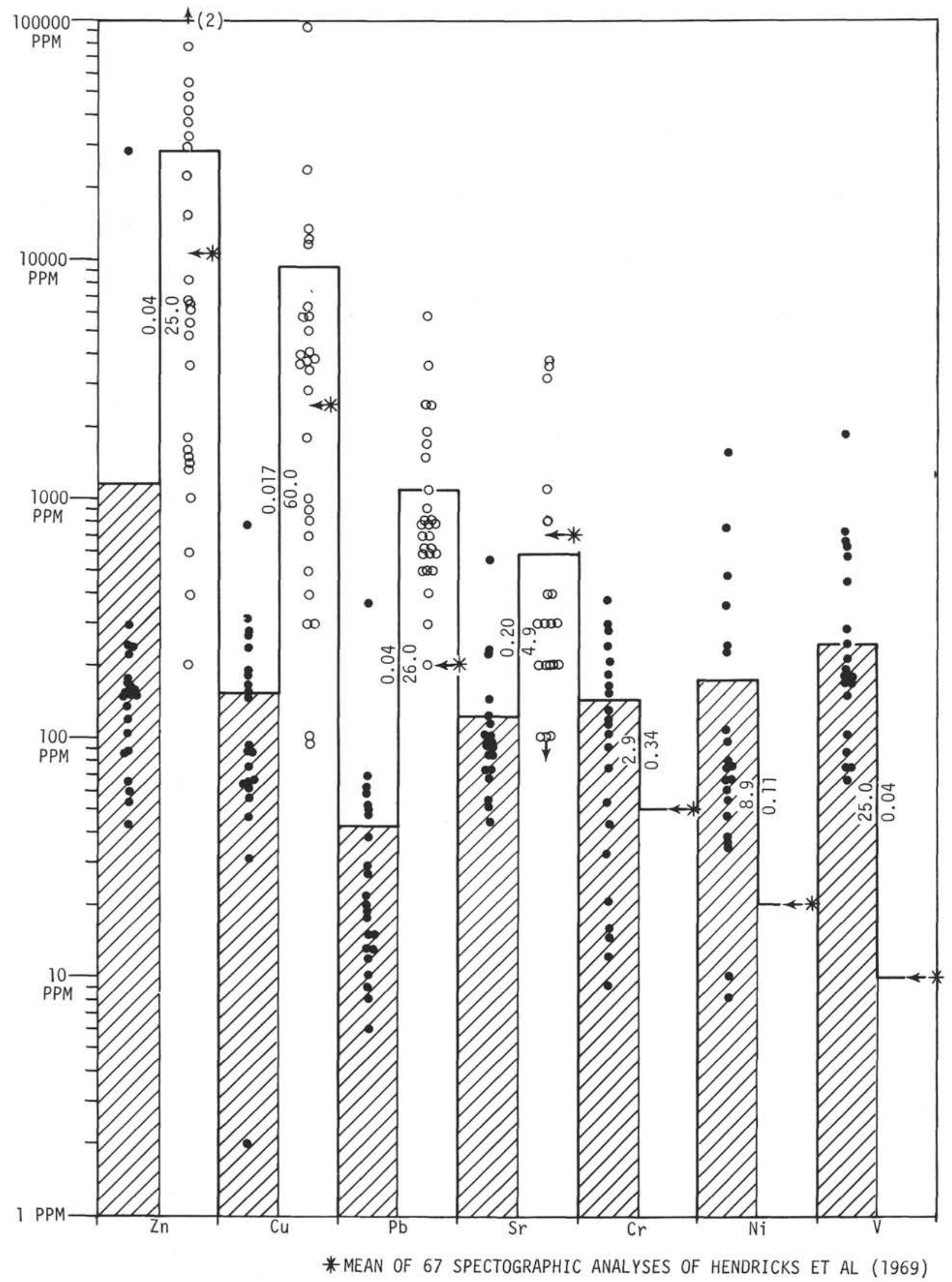

Figure 18. Comparison between minor elements contents (ignited sample basis) of the multicolored sediments of Hole 105 and the hot brine deposite of the Red Sea. Solid dots are Hole 105 data; open circles are Red Sea data, (Bischoff, 1969, and Hendricks et al., 1969). Horizontal bars are means; numbers are difference factors between means. 
TABLE 1

Chemical Analyses (X-Ray Fluorescence) of Samples from Upper Cretaceous to Lower Tertiary (?) Multicolored Zone. (Y. Lancelot and M.C. Sichere, Analysts.)

\begin{tabular}{|c|c|c|c|c|c|c|c|c|c|c|c|c|c|}
\hline \multicolumn{4}{|c|}{ Hole 105} & \multicolumn{9}{|c|}{ Per cent } & \multirow{2}{*}{$\begin{array}{l}\text { Ignition } \\
\text { Loss } \\
850^{\circ} \mathrm{C}\end{array}$} \\
\hline $\begin{array}{l}\text { Depth } \\
\text { (m) }\end{array}$ & $\begin{array}{c}\text { Core } \\
\text { No.. }\end{array}$ & $\begin{array}{l}\text { Section } \\
\text { No. }\end{array}$ & $\begin{array}{c}\text { Interval } \\
(\mathrm{cm})\end{array}$ & $\mathrm{SiO}$ & $\mathrm{Al}_{2} \mathrm{O}_{3}$ & $\mathrm{Fe}_{2} \mathrm{O}_{3}$ & $\mathrm{MgO}$ & $\mathrm{CaO}$ & $\mathrm{K}_{2} \mathrm{O}$ & $\mathrm{TiO}_{2}$ & $\mathrm{MnO}$ & Sum & \\
\hline 241.82 & \multirow[t]{4}{*}{5} & \multirow[t]{3}{*}{1} & $82-83$ & 52.17 & 14.11 & 20.72 & 2.54 & 0.66 & 1.95 & 0.82 & 3.140 & 96.09 & 20.07 \\
\hline 242.37 & & & $137-138$ & 68.22 & 22.29 & 8.44 & 3.97 & 0.70 & 2.89 & 0.80 & 0.013 & 107.32 & 14.46 \\
\hline 242.45 & & & $145-146$ & 59.36 & 19.46 & 6.90 & 3.12 & 0.81 & 2.94 & 0.90 & 0.400 & 93.89 & 11.56 \\
\hline 244.34 & & 3 & $34-36$ & 65.17 & 18.81 & 5.18 & 5.84 & 0.73 & 2.13 & 0.41 & 0.300 & 98.57 & 13.84 \\
\hline 250.72 & \multirow[t]{3}{*}{6} & \multirow[t]{3}{*}{1} & $72-73$ & 71.71 & 21.78 & 7.20 & 3.24 & 0.46 & 3.54 & 1.00 & 0.032 & 108.96 & 10.89 \\
\hline 250.93 & & & $93-94$ & 69.34 & 23.76 & 2.86 & 3.85 & 0.69 & 3.80 & 1.04 & 0.060 & 105.40 & 10.67 \\
\hline 250.96 & & & $96-97$ & 71.38 & 12.40 & 6.78 & 2.90 & 0.53 & 1.82 & 1.04 & 0.039 & 101.89 & 9.29 \\
\hline 259.00 & \multicolumn{3}{|c|}{ Core Catcher } & 61.11 & 22.48 & 7.96 & 2.52 & 0.52 & 3.74 & 1.08 & 0.060 & 99.47 & 9.84 \\
\hline 268.37 & \multirow[t]{4}{*}{8} & \multirow[t]{2}{*}{1} & $37-38$ & 77.95 & 13.80 & 5.53 & 1.37 & 0.32 & 2.86 & 2.02 & 0.760 & 104.61 & 5.68 \\
\hline 268.60 & & & $60-61$ & 74.35 & 17.52 & 6.89 & 1.80 & 0.33 & 2.96 & 1.19 & 0.200 & 105.17 & 7.09 \\
\hline 269.53 & & 2 & $3-4$ & 82.19 & 8.03 & 3.46 & 0.75 & 0.23 & 2.10 & 1.67 & 0.620 & 99.05 & 3.63 \\
\hline 273.95 & & 4 & $145-146$ & 70.98 & 27.78 & 3.33 & 3.87 & 0.65 & 1.39 & 0.33 & 0.050 & 108.40 & 18.77 \\
\hline 286.71 & \multirow[t]{12}{*}{9} & 1 & $71-73$ & 67.10 & 20.73 & 7.23 & 1.84 & 0.63 & 3.31 & 1.08 & 0.580 & 102.50 & 10.14 \\
\hline 287.57 & & \multirow[t]{6}{*}{2} & $7-8$ & 58.56 & 24.21 & 9.39 & 2.30 & 0.55 & 4.24 & 1.00 & 0.110 & 100.36 & 11.74 \\
\hline 287.81 & & & $31-36$ & 65.34 & 24.41 & 3.81 & 3.57 & 0.55 & 2.06 & 0.79 & 0.050 & 100.58 & 17.12 \\
\hline 288.20 & & & $70-71$ & 55.89 & 22.06 & 11.53 & 2.44 & 0.56 & 4.22 & 0.94 & 0.060 & 97.70 & 1.56 \\
\hline 288.65 & & & $115-116$ & 43.52 & 12.66 & 30.42 & 2.65 & 0.52 & 2.82 & 0.50 & 0.110 & 93.20 & 12.63 \\
\hline 288.81 & & & $131-132$ & 62.68 & 21.78 & 2.88 & 4.78 & 0.61 & 2.55 & 0.78 & 0.030 & 97.69 & 16.62 \\
\hline 288.95 & & & $145-146$ & 63.73 & 21.18 & 9.30 & 3.25 & 0.63 & 4.40 & 0.89 & 0.050 & 103.40 & 12.28 \\
\hline 289.41 & & \multirow[t]{3}{*}{3} & $41-42$ & 50.91 & 15.54 & 23.40 & 2.96 & 0.50 & 3.59 & 0.64 & 0.050 & 97.67 & 12.74 \\
\hline 290.29 & & & $129-130$ & 59.35 & 15.99 & 6.66 & 2.22 & 0.72 & 5.06 & 0.65 & 0.030 & 90.68 & 32.76 \\
\hline 290.36 & & & $136-137$ & 47.11 & 16.38 & 25.61 & 4.01 & 0.51 & 1.04 & 0.31 & 0.010 & 96.98 & 21.32 \\
\hline 291.75 & & 4 & $125-126$ & 66.79 & 17.99 & 6.89 & 3.14 & 0.63 & 4.44 & 0.79 & 0.030 & 100.70 & 10.82 \\
\hline 292.78 & & 5 & $78-79$ & 61.05 & 19.49 & 5.18 & 3.26 & 0.71 & 4.22 & 0.71 & 0.003 & 94.65 & 18.22 \\
\hline \multicolumn{4}{|c|}{ Means } & 63.58 & 18.94 & 9.48 & 3.01 & 0.57 & 3.09 & 0.89 & 0.28 & 100.29 & 13.07 \\
\hline \multicolumn{4}{|c|}{ Standard Deviation } & 9.20 & 4.56 & 7.41 & 1.07 & 0.14 & 1.04 & 0.37 & 0.63 & 4.74 & 6.33 \\
\hline
\end{tabular}

Leg 11. All the Tertiary deposits are above seismic Horizon "A."

\section{Sedimentary Structures}

The primary sedimentary structures noted in the hemipelagic sediment are horizontal laminations, lenses and spots of very fine silt, lenses and nodules of siderite, and near the top of the section, occasional layers of foraminifera. Very fine stratification is only noticed after close examination, and the sediment is, in general, structurally very homogeneous. At the hiatus between the early Pleistocene and late Miocene a well-indurated crust of limy mud containing cemented burrow fillings was noticed.

The expansion of clathrate upon recovery of cores from the deeper parts of Holes 102, 103 and 104 created many voids and produced a generally spongy sediment. No doubt any existing primary structure in this material would have been destroyed.

The cores recovered from the lower part of Hole 106 are well indurated and show well-preserved sedimentary structures (Figure 19). Some of them resemble 
TABLE 2

Trace Element Analysis of Samples from Upper Cretaceous to Lower Tertiary (?) Multicolored Zone

(Spectographic quantometer analyses by the Societé Nationale des Pétroles d'Aquitaine, Pau, France. Courtesy of Dr. Georges Kulbicki)

\begin{tabular}{|c|c|c|c|c|c|c|c|c|c|c|c|c|c|c|c|c|}
\hline \multicolumn{4}{|c|}{ Hole 105} & \multicolumn{13}{|c|}{ PPM (ignited sample, $900^{\circ} \mathrm{C}$ ) } \\
\hline $\begin{array}{l}\text { Depth } \\
\text { (m) }\end{array}$ & $\begin{array}{c}\text { Core } \\
\text { No. }\end{array}$ & $\begin{array}{l}\text { Section } \\
\text { No. }\end{array}$ & $\begin{array}{c}\text { Interval } \\
(\mathrm{cm})\end{array}$ & B & V & Mo & $\mathrm{Pb}$ & $\mathrm{Zn}$ & $\mathrm{Cu}$ & $\mathrm{Cr}$ & $\mathrm{Ni}$ & Co & $\mathrm{Sr}$ & $\mathrm{Ba}$ & $\mathrm{Ga}$ & $\mathrm{Mn}$ \\
\hline 241.82 & 5 & 1 & $82-83$ & - & - & - & - & \multicolumn{3}{|c|}{ not analyzed } & - & - & - & - & - & - \\
\hline 242.37 & & & $137-138$ & 172 & 150 & 2 & 10 & 148 & 248 & 205 & 97 & 17 & 98 & 234 & 14 & 380 \\
\hline 242.45 & & & $145-146$ & 162 & 179 & 3 & 50 & 139 & 167 & 129 & 108 & 27 & 123 & 431 & 18 & 2500 \\
\hline 244.34 & & 3 & $34-36$ & 67 & 73 & 1 & 22 & 171 & 303 & 43 & 94 & 14 & 117 & 134 & 8 & 1630 \\
\hline 250.72 & 6 & 1 & $72-73$ & 178 & 167 & 1 & 15 & 145 & 57 & 241 & 74 & 14 & 69 & 198 & 17 & 230 \\
\hline 250.93 & & & 93-94 & 167 & 167 & 4 & 12 & 151 & 87 & 249 & 78 & 13 & 87 & 212 & 15 & 330 \\
\hline 250.96 & & & $96-97$ & 209 & 673 & 0 & 9 & 159 & 65 & 151 & 38 & 15 & 55 & 42 & 8 & 210 \\
\hline 259.00 & \multicolumn{3}{|c|}{ Core Catcher } & 171 & 179 & 2 & 15 & 165 & 65 & 181 & 60 & 14 & 91 & 282 & 20 & 450 \\
\hline 268.37 & 8 & 1 & $37-38$ & 148 & 183 & 104 & 69 & 87 & 158 & 91 & 472 & 155 & 120 & 369 & 24 & $*$ \\
\hline 268.60 & & & $60-61$ & 136 & 100 & 6 & 20 & 54 & 46 & 73 & 36 & 14 & 44 & 211 & 3 & 1790 \\
\hline 269.53 & & 2 & $3-4$ & 161 & 85 & 3 & 13 & 43 & 31 & 53 & 24 & 14 & 53 & 185 & 0 & 3480 \\
\hline 273.95 & & 4 & $145-146$ & 299 & 66 & 0 & 6 & 154 & 60 & 32 & 10 & 8 & 73 & 153 & 16 & 870 \\
\hline 286.71 & 9 & 1 & $71-73$ & 152 & 173 & 5 & 58 & 86 & 93 & 104 & 75 & 20 & 114 & 541 & 19 & 4490 \\
\hline 287.57 & & 2 & $7-8$ & 143 & 190 & 1 & 19 & 104 & 237 & 119 & 66 & 10 & 96 & 297 & 20 & 750 \\
\hline 287.81 & & & $31-36$ & 273 & 72 & 1 & 8 & 248 & 86 & 9 & 8 & 2 & 85 & 10 & 22 & 310 \\
\hline 288.20 & & & $70-71$ & 156 & 654 & 1 & 47 & 179 & 90 & 163 & 47 & 14 & 100 & 418 & 22 & 400 \\
\hline 288.65 & & & $115-116$ & 158 & 707 & 18 & 52 & 159 & 265 & 285 & 81 & 53 & 551 & * & 20 & 1250 \\
\hline 288.81 & & & $131-132$ & 159 & 450 & 0 & 365 & 240 & 779 & 16 & 35 & 5 & 73 & 108 & 14 & 180 \\
\hline 288.95 & & & $145-146$ & 149 & 165 & 1 & 13 & 120 & 75 & 147 & 36 & 10 & 91 & 327 & 19 & 350 \\
\hline 289.41 & & 3 & $41-42$ & 154 & 565 & 12 & 62 & 221 & 187 & 327 & 67 & 18 & 101 & 268 & 16 & 500 \\
\hline 290.29 & & & $129-130$ & 190 & 1803 & 165 & 29 & 292 & 180 & 205 & 733 & 59 & 230 & 215 & 22 & 170 \\
\hline 290.36 & & & $136-137$ & 150 & 248 & 80 & 38 & 59 & 2 & 12 & 1539 & 27 & 74 & 14 & 36 & 120 \\
\hline 291.75 & & 4 & $125-126$ & 138 & 213 & 0 & 18 & 64 & 64 & 116 & 55 & 10 & 147 & 229 & 13 & 210 \\
\hline 292.78 & & 5 & $78-79$ & 193 & 280 & 0 & 27 & 148 & 146 & 373 & 228 & 67 & 224 & 1521 & 16 & 130 \\
\hline Means & & & & 169 & 248 & 18 & 42 & 145 & 152 & 145 & 177 & 26 & 122 & 291 & 17 & 942 \\
\hline Stand: & ard de & eviation & & 44.6 & 276 & 40.5 & 71.3 & 63.1 & 156 & 100 & 332 & 32 & 102 & 298 & 7.2 & 1149 \\
\hline
\end{tabular}

* Over the saturation point of the quantometer

worm burrows but are generally coalescent and sometimes lenticular. They often merge into vertical structures that are responsible for fracturing of the indurated sediments. These vertical structures are often lined with siderite and are probably the result of upward migration of gas (see Lancelot and Ewing, this volume). As the presence of worm burrows is unlikely in these sediments, owing to very high rates of sedimentation and reducing conditions, and because of the close relation between the burrow-like structures and the vertical structures, we believe that circulation of gas has been responsible for these primary structures. They show some similarities with those described by P. Cloud (1960) in various types of gas-rich sediments. 
TABLE 3

Comparison of the Minerals Present in the Red Sea Hot Brine Deposits with Those of the

Multicolored Zone of Hole 105. (X indicates most prominent minerals, names of minerals common to both areas are underlined.)

\begin{tabular}{|c|c|c|c|c|}
\hline \multicolumn{3}{|c|}{ Minerals } & \multirow{2}{*}{$\begin{array}{c}\begin{array}{c}\text { Red Sea } \\
\text { Brine Deposits }^{\mathrm{a}}\end{array} \\
\mathrm{X}\end{array}$} & \multirow{2}{*}{$\frac{\begin{array}{c}\text { Leg } 11 \\
\text { Site } 105^{\mathrm{b}}\end{array}}{\mathrm{X}}$} \\
\hline \multirow{10}{*}{$\mathrm{Fe}$} & goethite & $\mathrm{Fe} 00 \mathrm{H}$ & & \\
\hline & hematite & $\mathrm{Fe}_{2} \mathrm{O}_{3}$ & $\mathrm{X}$ & $\mathrm{X}$ \\
\hline & lepidocrocite & $\mathrm{Fe} 00 \mathrm{H}$ & $\mathrm{X}$ & \\
\hline & $\mathrm{Fe}$-montmorillonite & & $\mathrm{x}$ & $\mathrm{X}$ \\
\hline & pyrite & $\mathrm{Fe}_{2} \mathrm{~S}$ & $\mathrm{X}$ & $\mathrm{X}$ \\
\hline & marcasite & $\mathrm{Fe}_{2} \mathrm{~S}$ & $\mathrm{X}$ & \\
\hline & pyrrhotite & $\mathrm{FeS}$ & $\mathrm{X}$ & \\
\hline & greigite & $\mathrm{Fe}_{3} \mathrm{~S}_{4}$ & $\mathrm{X}$ & \\
\hline & amorphous material & $\mathrm{Fe}+?$ & $\mathrm{X}$ & $\mathrm{X}$ \\
\hline & siderite & $\mathrm{FeCO}_{3}$ & $\mathrm{x}$ & $\mathrm{x}$ \\
\hline \multirow{5}{*}{$\mathrm{Mn}$} & rhodochrosite & $\mathrm{MnCO}_{3}$ & $\mathrm{x}$ & \\
\hline & groutite & $\mathrm{Mn} 00 \mathrm{H}$ & $\mathrm{x}$ & $X(?)$ \\
\hline & manganite & $\mathrm{MnOOH}$ & $\mathrm{X}$ & \\
\hline & todorokite & $(\mathrm{Mn},+)_{3} \cdot \mathrm{H}_{2} \mathrm{O}$ & $\mathrm{x}$ & $\mathrm{X}$ \\
\hline & woodruffite & $(\mathrm{Zn}, \mathrm{Mn}) \mathrm{O}_{\mathrm{n}} \cdot \mathrm{H}_{2} \mathrm{O}$ & $\mathrm{X}$ & \\
\hline $\mathrm{Zn}$ & sphalerite & $\mathrm{ZnS}$ & $\mathrm{x}$ & $\mathrm{x}$ \\
\hline $\mathrm{Cu}$ & chalcopyrite & CuFes & $\mathrm{x}$ & \\
\hline \multirow{2}{*}{$\mathrm{Si}$} & clinoptilolite & (Zeolite) & & $\mathrm{X}$ \\
\hline & phillipsite & (Zeolite) & & $\mathrm{X}$ \\
\hline \multirow{2}{*}{$\mathrm{Al}$} & mica & & & $\mathrm{x}$ \\
\hline & kaolinite & & & $\mathrm{X}$ \\
\hline $\mathrm{Ba}$ & barite & $\mathrm{BaSO}_{4}$ & $\mathrm{x}$ & \\
\hline $\mathrm{Ca}$ & anhydrite & $\mathrm{CaSO}_{4}$ & $\mathrm{x}$ & \\
\hline $\mathrm{Na}$ & halite & $\mathrm{NaCl}$ & $\mathrm{x}$ & \\
\hline
\end{tabular}

${ }^{\mathrm{a}}$ Bischoff (1969)

${ }^{b}$ Zemmels, Cook and Hathaway (this volume)

\section{Composition}

The 9 meters of Pliocene sediment recovered at Site 99 is predominantly nannoplankton ooze with contamination from the overlying foraminifera-rich Pleistocene material. Clay minerals are the predominant Tertiary nonbiogenous component at this location. Approximately 10 meters of Pliocene and 20 meters of
Miocene sediment recovered at Site 101 is hemipelagic greenish-gray silty mud. Clay minerals, quartz silt, heavy minerals, and pyrite are the dominant nonbiogenous components, whereas reworked or winnowed Tertiary foraminifera and nannofossils dominate the biogenous contribution. Also included are reworked Cretaceous and Carboniferous pollen. 


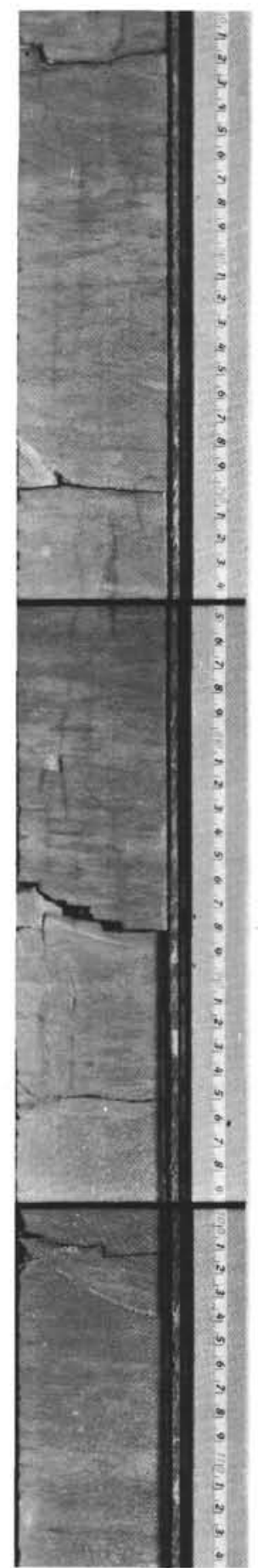

$106 \mathrm{~B}-5-5$
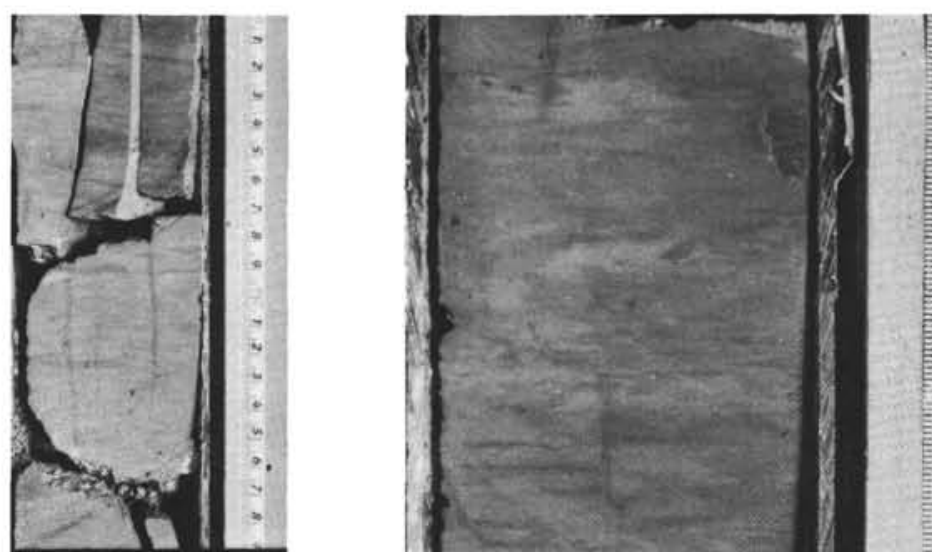

-

E0

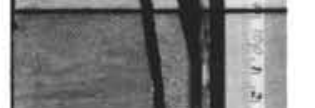

\section{,}

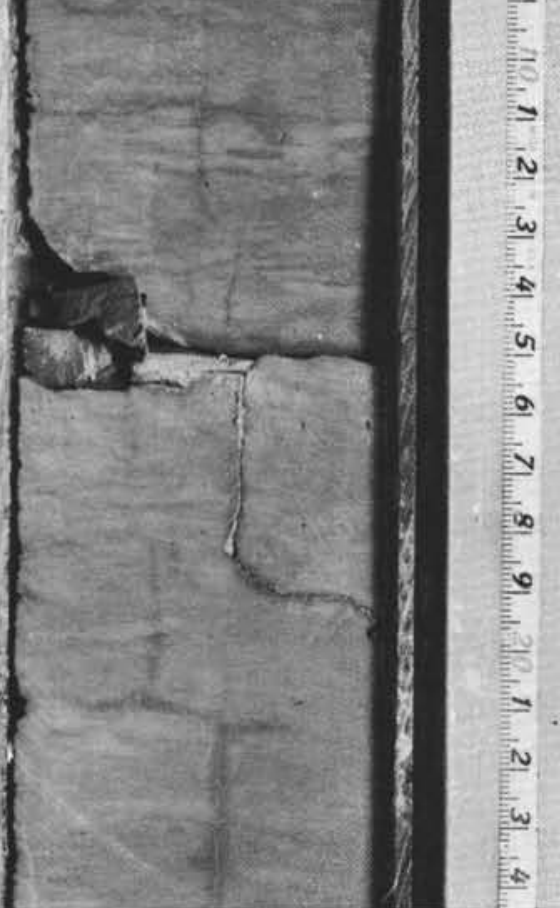

$106 \mathrm{~B}-5-5$

Figure 19. Sedimentary structures caused by gas migration in hemipelagic mud from Site 106. Note the vertical structures lined with light-colored siderite; some of these structures are responsible for vertical fracturation in the cores (see 106B-5-6, 80 to $95 \mathrm{~cm}$ ). Note also the "burrow-like" structures in lower half of 106B-5-6. 
The clay minerals (Figures 20, 21 and 22) of this and of all the remaining holes that contain Tertiary material (Holes 102 through 106) show distinctive patterns that suggest that the Tertiary clays have a common source. Chlorite and mica tend to decrease in abundance down-hole, whereas kaolinite tends to increase in abundance. These trends reflect a probably gradual climatic cooling between the middle Miocene and the late Pliocene followed by a drastic cooling trend during the Pleistocene.

The sediments recovered from Sites 102, 103 and 104, correlated on the basis of a common biostratigraphic zone (N. 17) as well as on compositional similarities, are considered as a single sequence of Tertiary and Quaternary sediment (middle Miocene to Holocene), representing the upper kilometer of sediment that forms the top of the Blake-Bahama Outer Ridge. Middle Miocene sediment is rich in siliceous microfossils, clay minerals, and siderite. Sediments of late Miocene to Pliocene age contain more calcareous microfossils and abundant pyrite and glauconite. All of this material is silty, greenish-gray mud. Below 100 meters below bottom, the sediment was very gassy, containing mostly methane with a trace of ethane. Hydrogen sulphide was detected in shallow sediments from Hole 104.

The X-ray mineralogy of the fine clays (less than 2 micrometers) in the Miocene and Pliocene sediments of the Blake-Bahama Outer Ridge, as well as those samples of comparable age from the continental rise further north (105 and 106) show striking similarities (Figures 20, 21, and 22).

The percentage of kaolinite increases gradually with increasing age of sediment, from 5 to 10 per cent in Pleistocene clays to 20 per cent in middle Miocene clays. Samples of the same age are very similar with respect to the amount of mica and chlorite. The data show a gradual decrease in relative amounts of chlorite and mica from Pliocene to the middle Miocene.

The Tertiary sediment (Pliocene and Miocene from Site 105 and Pliocene-Eocene of Hole 106) is nearly indistinguishable from the greenish-gray hemipelagic Tertiary muds of the Blake-Bahama Outer Ridge.

The material of Miocene and Pliocene age is composed primarily of clay minerals, quartz silt, pyrite and calcareous nannoplankton. Paleocene-Oligocene material contains abundant siliceous microfossils and is nearly barren of calcareous forms. Calcite decreases and siderite increases downhole, suggesting that they may form a replacement series (see Lancelot and Ewing, this volume). The Oligocene/Eocene material near the bottom of Site 106 contains a large amount of disordered cristobalite which is largely responsible for the high degree of induration of the clay.

\section{Lithification and Diagenesis}

In general, sediment becomes harder with depth below the sea floor; however, certain exceptions occur (see Physical Properties chapter in this volume). The upper and middle Miocene sections of the Tertiary hemipelagic mud tend to be quite hard and appear dry upon exposure. The material quickly absorbs water and becomes crumbly when placed in water.

At Site 99 in Cat Gap, the soft Pliocene foraminiferalnannofossil ooze was partially disturbed by the drilling operations; however, a few fragments of brown chert were noted. They may represent the remains of a small chert bed. Some of the clay mineral appeared to be coated with iron oxide. Recrystallized calcite and dolomite were also noted, and their occurrence represents a minor degree of diagenesis.

The Tertiary sediment recovered at Site 101 near the southern end of the Blake-Bahama Outer Ridge system (Pliocene and Miocene) is soft hemipelagic greenishgray silty clay. No significant lithification was noted; however, the material contains abundant pyrite specks, micronodules, and a few larger nodules of pyrite as well as siderite. Authigenic siderite rhombs and rutile needles are also common.

The 135 meters of Tertiary sediment recovered (Pliocene and Miocene) from the three holes on the BlakeBahama Outer Ridge are all comparatively homogeneous greenish-gray hemipelagic mud. The sediment becomes harder and drier with depth. The main diagenetic forms include pyrite, siderite and occasionally dolomite, which become more abundant with depth. Dolomite is particularly abundant in the upper Miocene portion of Hole 103 (Figure 23). The middle Miocene silty mud is very hard and brittle and has been lithified to a mudstone. Except for the upper few meters, all the ridge sediment was highly disturbed by the expansion of methane gas.

Greenish-gray hemipelagic mud of Pliocene to middle Miocene age was recovered at the base of the lower continental rise at Site 105. This material includes large nodules of pyrite and silt-sized pellets of rhodochrosite (Figure 24).

At Site 105, a gradual increase in sediment hardness was noted in the recovered Tertiary material (Pliocene to Eocene). Pyrite nodules were recovered from sediment of early Pliocene age, and siderite lenses and nodules are present in the middle Miocene. Near the bottom of the hole-in Oligocene and Eocene material-the sediment is highly lithified and is best described as mudstone. This material includes some flattened siderite-filled burrows and pyritized radiolarian tests. 


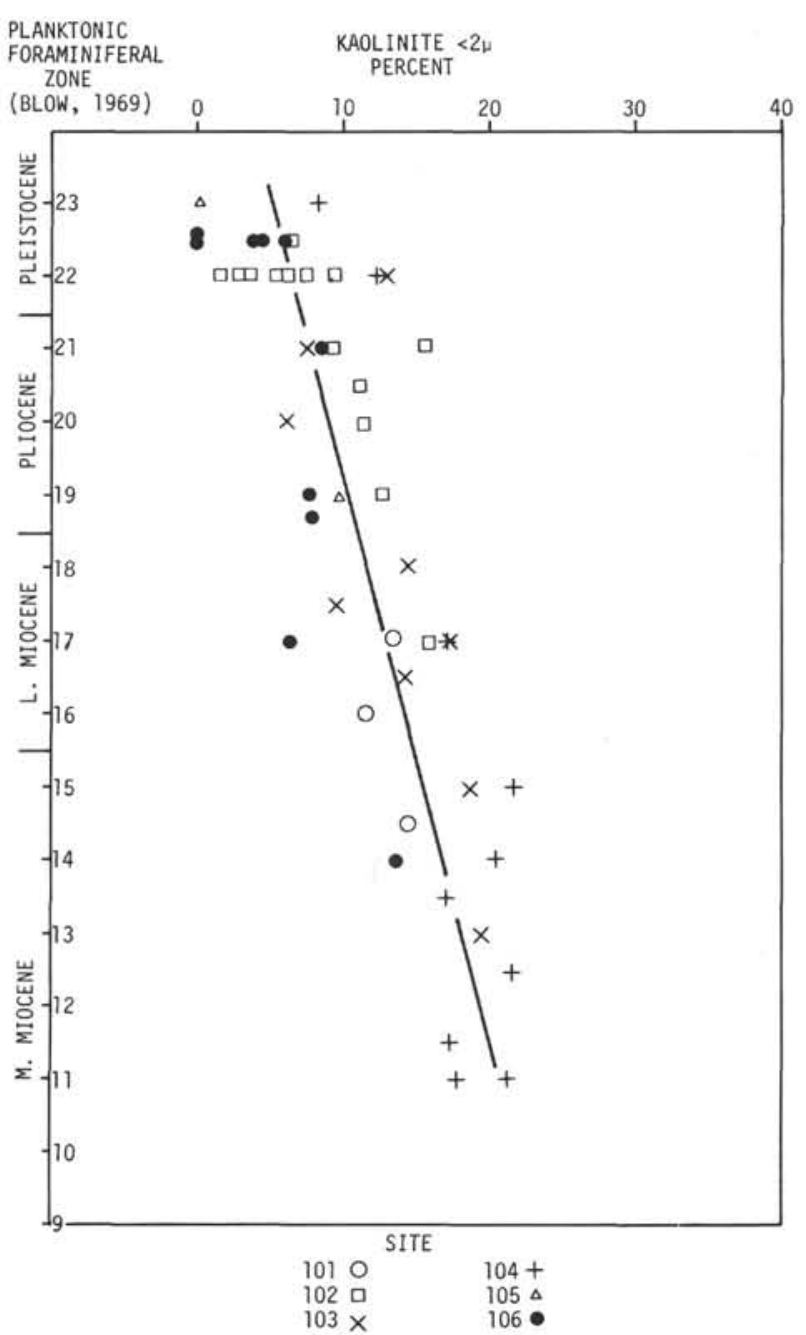

Figure 20. Kaolinite (less than 2 micrometer fraction) content (by percentage) versus age based on planktonic foraminifera (Blow, 1969). Kaolinite content from Zemmels, Cook and Hathaway, this volume.

Specific diagenesis problems related to the presence of gas in the sediments from Sites 102, 103, 104 and 106 are discussed in Lancelot and Ewing (this volume).

The siliceous-calcareous ooze at Site 108 is moderately indurated. No obvious diagenetic minerals were noted except for a few pyrite-filled burrows.

\section{Discussion}

The Tertiary silty clay represents the hemipelagic facies of the continental margin. The striking similarities in composition, structure, and rate of accumulation of all of this Tertiary sediment, whether recovered from the region of Cat Gap or more than 1000 kilometers further north on the continental rise off New York, strongly suggests a common source and process of sedimentation.

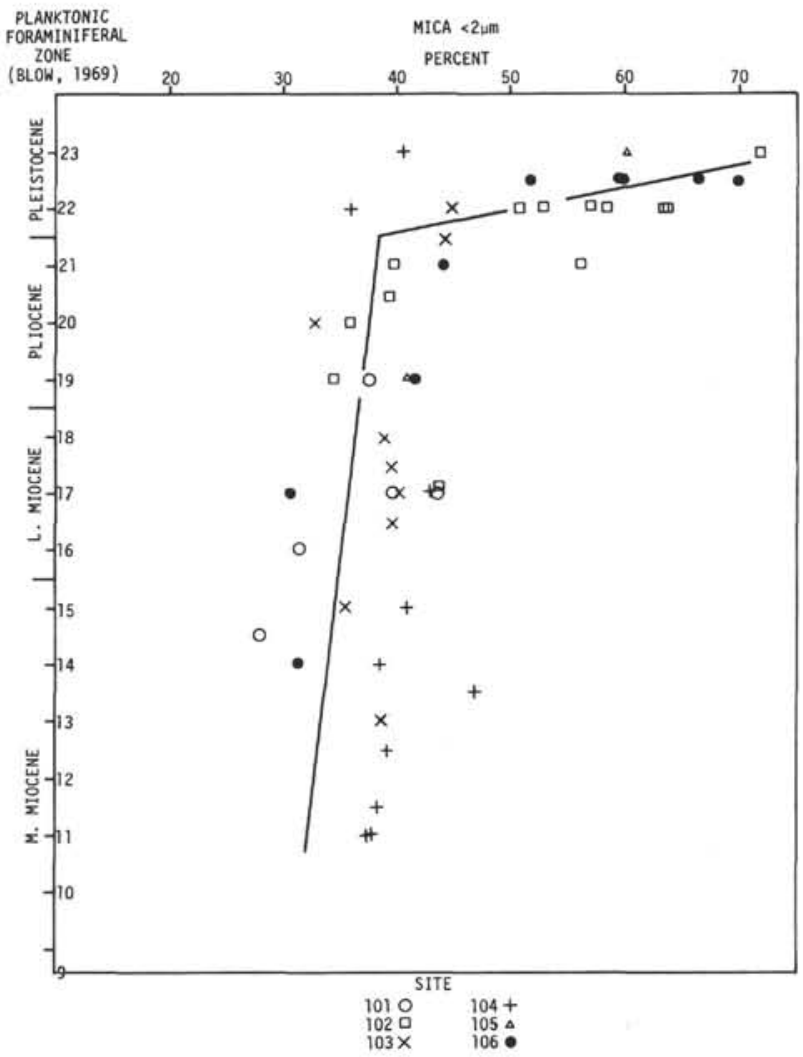

Figure 21. Mica (less than 2 micrometer fraction) content (by percentage) versus age based on planktonic foraminifera (Blow, 1969). Mica content from Zemmels, Cook and Hathaway, this volume.

This material is relatively rich in chlorite, mica and amphiboles and these minerals are believed to have been derived from sources north of Cape Hatteras (Hathaway, in press). It is apparent from these observations as well as from the observation that this sediment contains pollen with northern affinities (see Habib, this volume) that most of the sediment recovered from the Blake-Bahama Outer Ridge has been transported from the north by bottom currents in the manner described by Heezen et al. (1966).

The above similarities further suggest to the present authors that the continental rise sediments have had a similar transportational history. No evidence for turbidity current deposition was noted in any of the Tertiary sediments, and it is thus concluded that deposition on the continental margin, at least during the Tertiary, was dominated by the effects of oceanbottom currents.

No doubt, slumping, turbidity currents, pelagic deposition, and the seaward migration of continental detritus in the water column provided the primary source of the material; however, bottom currents appear to have been the final depositional agent. 


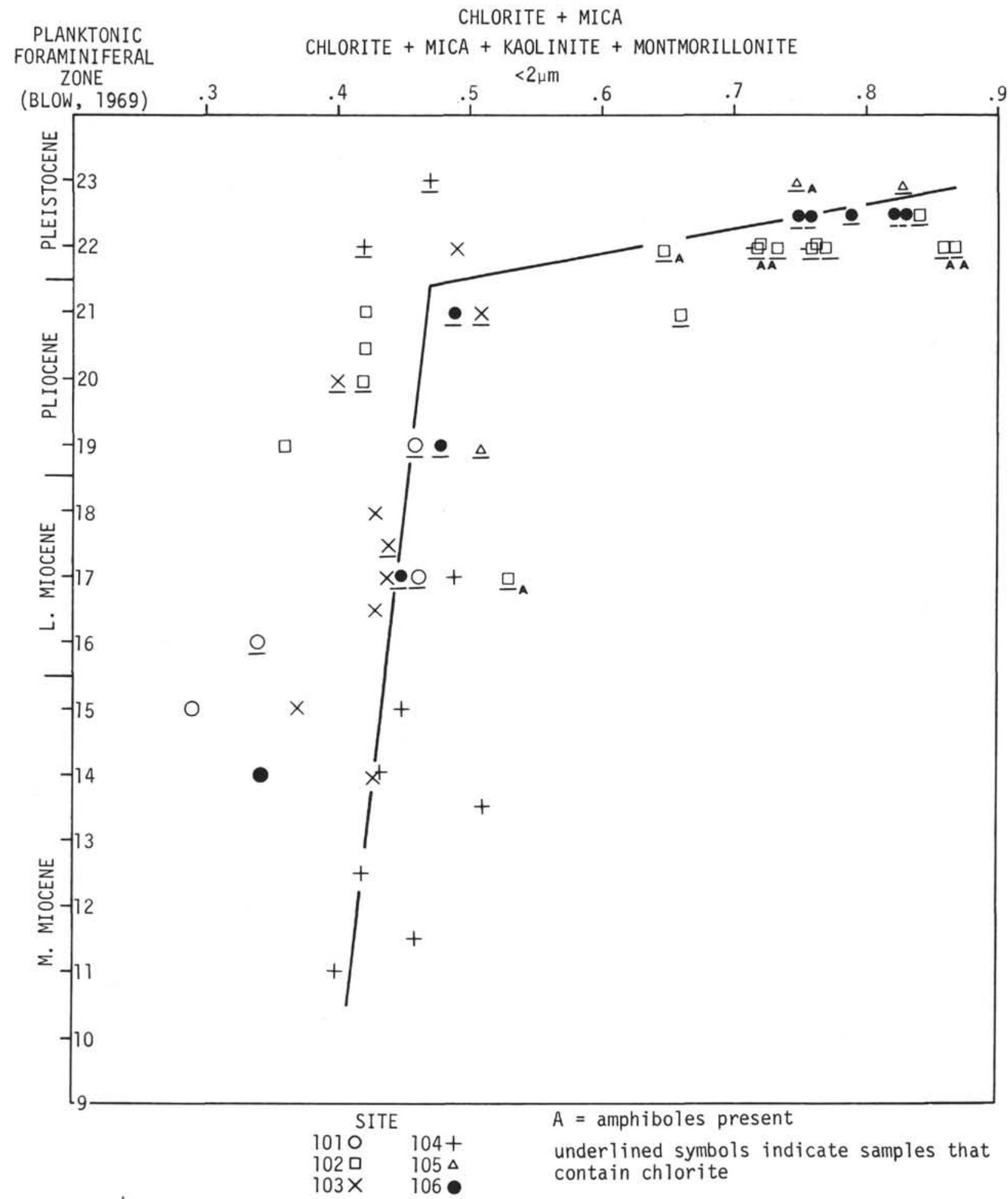

Figure 22. Ratio of chlorite content and mica content to total clay minerals (chlorite and mica/chlorite and mica and kaolinite and montmorillonite, all less than 2 micrometer fraction) versus age based on planktonic foraminifera (Blow, 1969). Clay mineral data from Zemmels, Cook and Hathaway, this volume). 


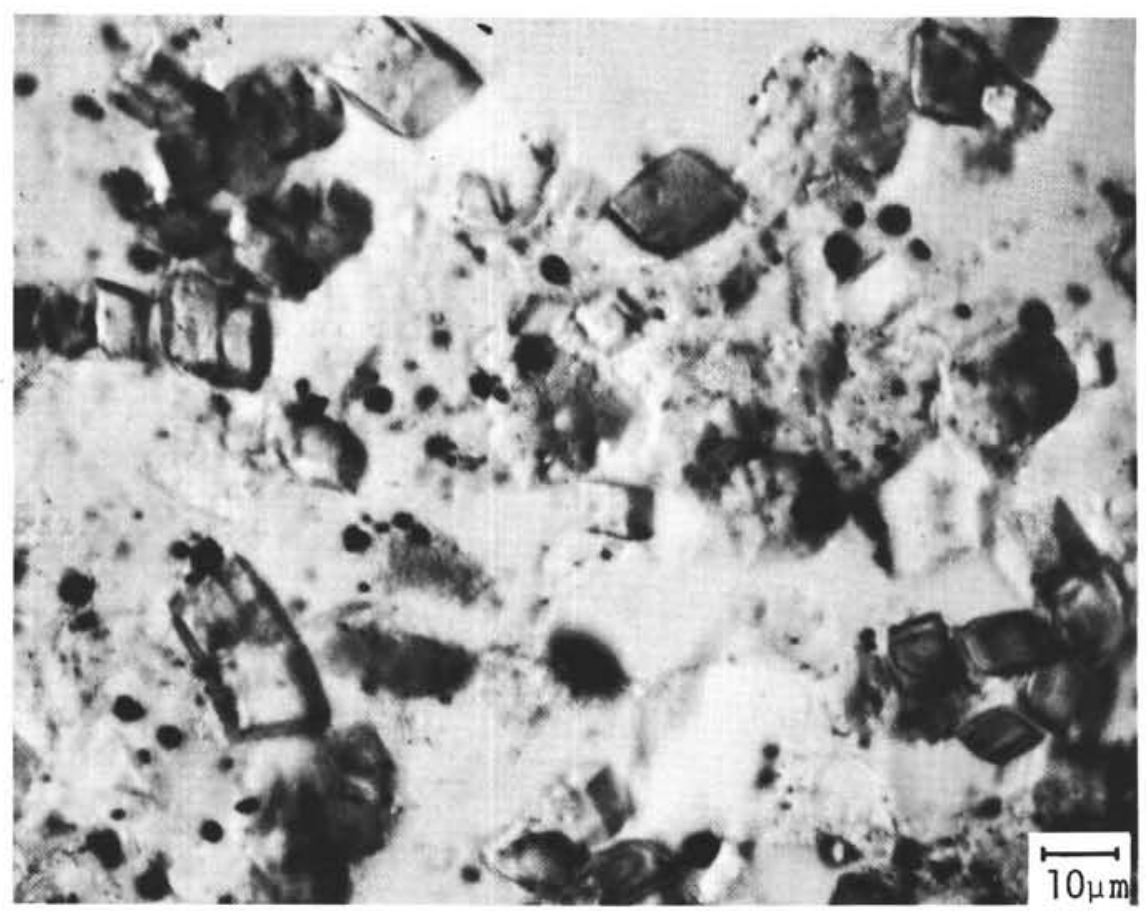

Figure 23. Photomicrograph of dolomite from Sample 103-2-6, 0 to $1 \mathrm{~cm}$ (partially crossed polarizers; substage elements slightly displaced to give shadow effect).

THE QUATERNARY DEPOSITS

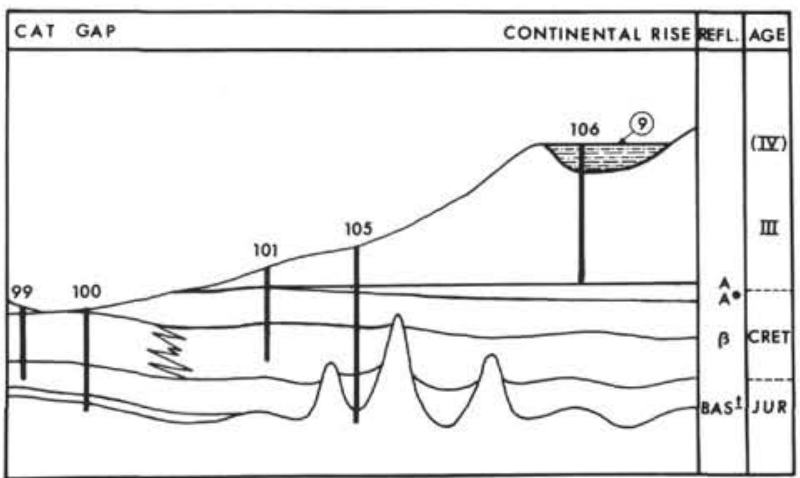

Quaternary sediments recovered at Site 99 in the Cat Gap, Sites 102, 103, 104 on the Blake-Bahama Outer Ridge, and Sites 106 and 107 on the continental rise. They are especially thick at Sites 102 and 106, where they accumulated at rates reaching $10 \mathrm{~cm} / 1000 \mathrm{yrs}$ in the Pleistocene.

\section{Pleistocene Sediments}

The Pleistocene sediments are predominantly terrigenous and contain large amounts of sand and silt. No sedimentary structures were preserved during the coring of these layers but there is reasonable evidence that at Site 106 they consist of turbidites. On the seismic profiler records from this region, the section identified as Pleistocene from drilling results corresponds to wellstratified, horizontal reflectors which fill a depression in the lower continental rise hills (see Site Report, and Ewing and Hollister, this volume). At Site 102, although the upper part of the section appears stratified on the profiler records (see Site Report), the sand content was much lower than at Site 106. At the latter site large sand beds and patches, completely disturbed and interbedded with clays and hemipelagic muds, occur. At Site 102 an increase in scattered terrigenous sand and silt was observed in the hemipelagic muds.

These sediments are predominantly terrigenous. Quartz, feldspars, micas, amphiboles, pyroxenes and garnet are abundant in the sand and silt-sized fractions; chlorite and mica dominate the clay-sized fraction (see Figures 20, 21 and 22). This composition is similar to that of most of the Quaternary deposits from the northern part of the North-American basin (north of Cape Hatteras) described from piston cores by Ericson 


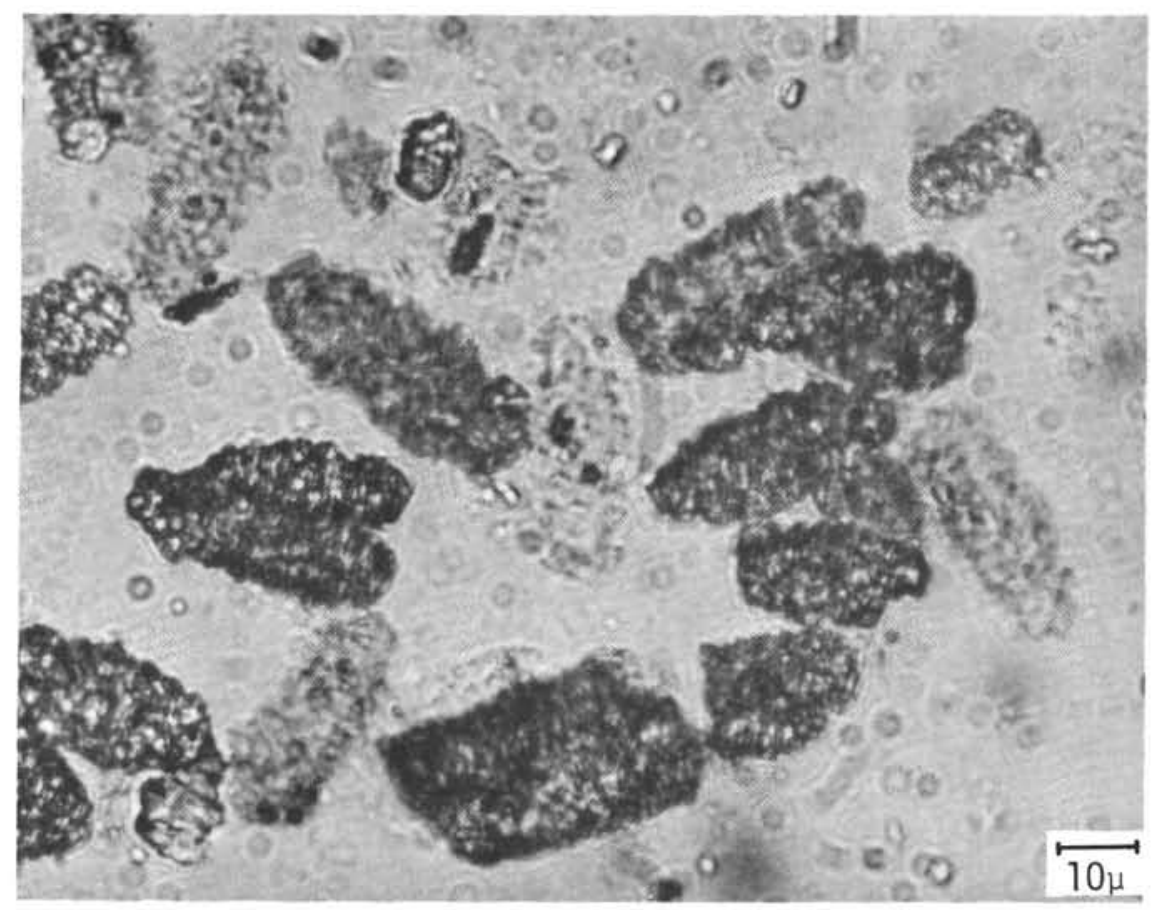

A

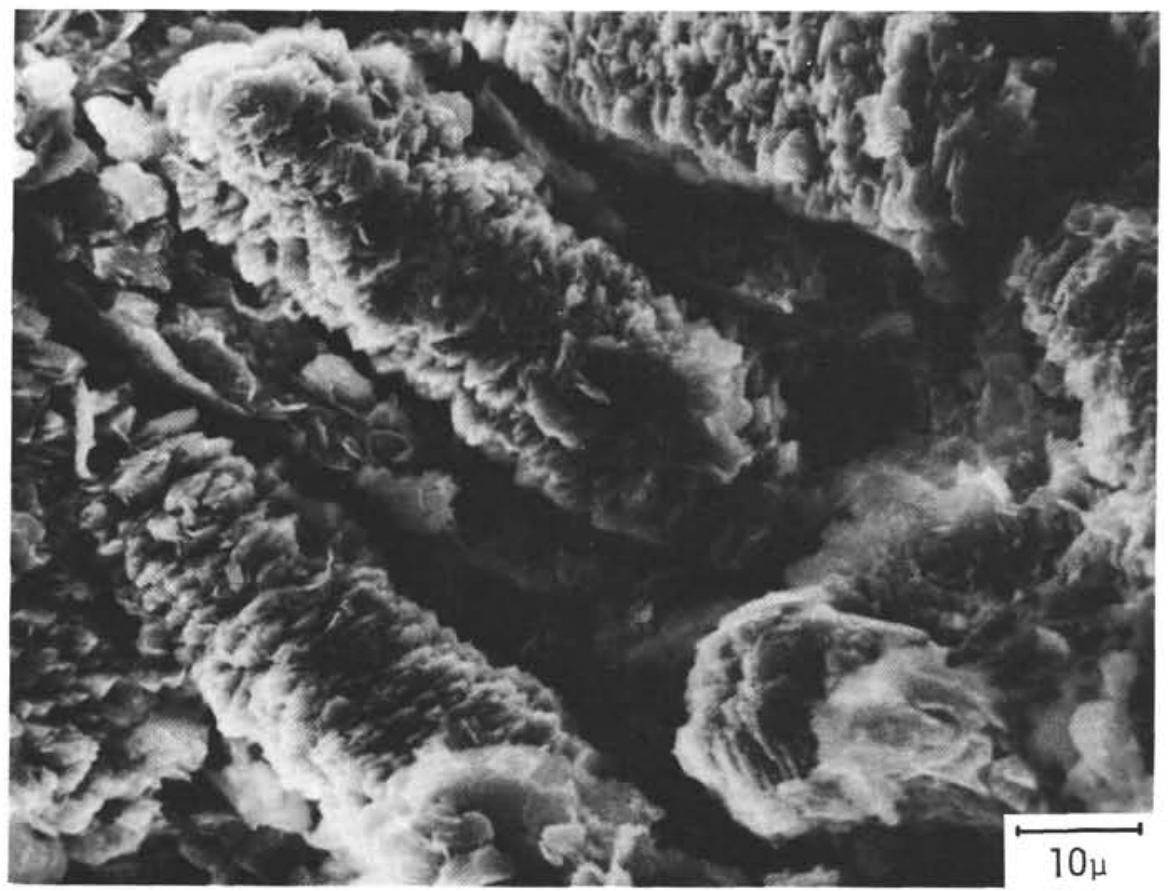

B

Figure 24. Rhodochrosite pellets.

A. Photomicrograph of Sample 105-4-3, 94 to $98 \mathrm{~cm}$ (plane polarized light). $B$ - D. Scanning electron micrographs of same sample at progressively higher magnifications, showing rhombic habit of rhodochrosite crystallites in pellets. 

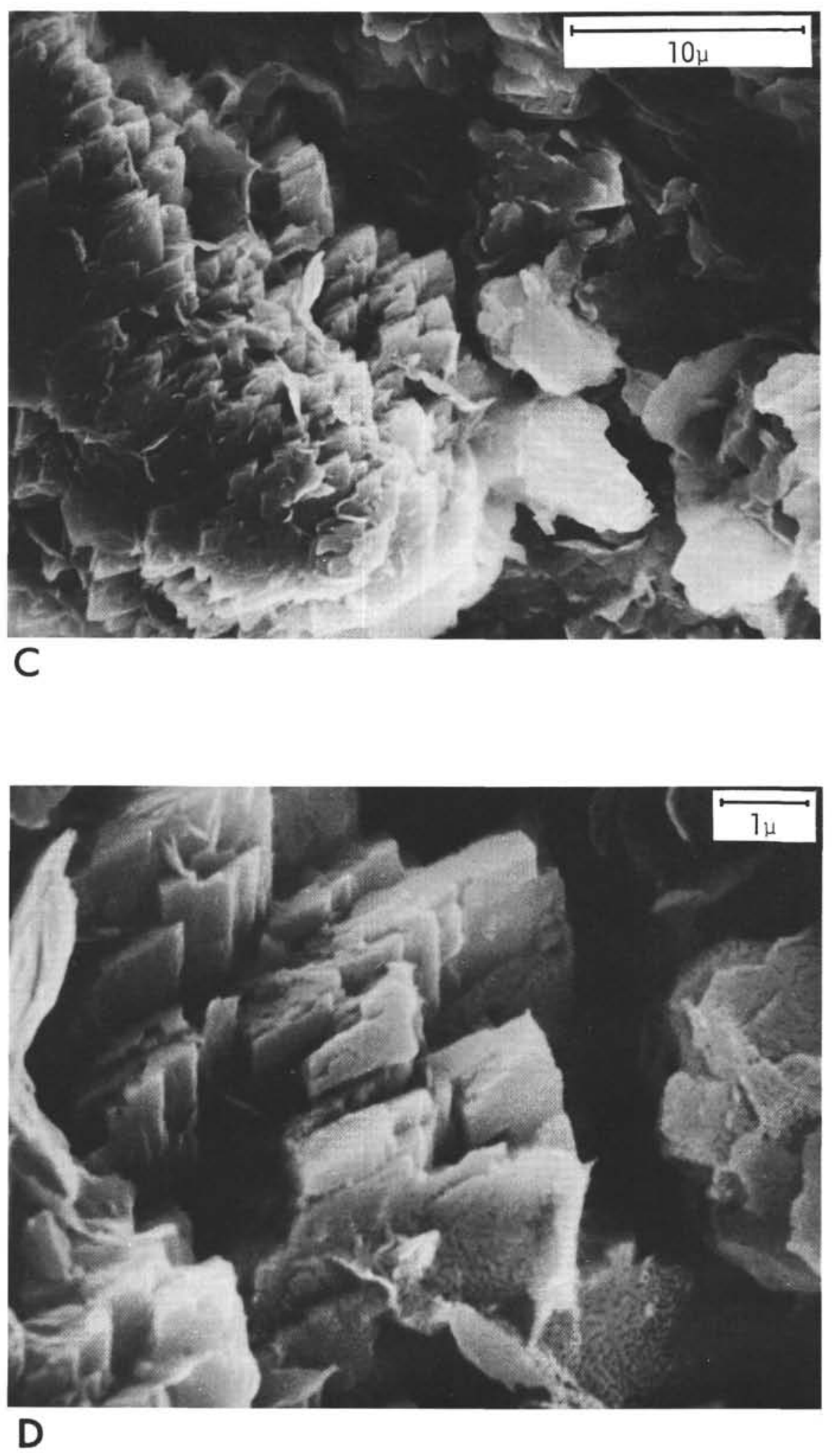

Figure 24-Continued 
et al. (1961), Hollister (1967), and Emery et al. (1970) (see also references in the latter). The same clay mineral assemblage is found all over the North American basin down to the Cat Gap area (Site 99).

These Pleistocene sediments appear to record the only major accumulation of coarse terrigenous detritus in the deep parts of the basin.

\section{Holocene}

Holocene sediments were poorly recovered during Leg 11 and are certainly best studied in piston cores (see Ericson et al., 1961). The sediments recovered during Leg 11 consist mainly of pelagic clayey carbonate oozes and brown clays that make a usually thin (probably not more than a few meters) cover above the Pleistocene. The mineral composition of the clays is the same as that of the Pleistocene sediments. The main characteristic of this interval seems to be the abrupt decrease in sedimentation rate from the Pleistocene to the Holocene. This decrease is apparently the result of a diminished terrigenous input and, consequently, the biogenic fraction is more concentrated than in the Pleistocene layers.

\section{Comments on the Lithification of Carbonate Deposits}

The cores recovered by drilling deep holes in marine sediments provide an exceptionally good opportunity to study lithification processes. However, such studies suffer from a lack of information on important variables that play a major role in these processes. Lithification, as most of the diagenetic processes, is the result of chemical reactions under conditions which are generally not directly observed in situ (for example $p \mathrm{H}$, $\mathrm{Eh}$, pressure, temperature and fluid circulation). Observations of the smear slides and some scanning electron microscope studies show that the lithification of carbonate sediments results mainly from cementation by intergranular precipitation of micritic calcite. The generally negative correlation between the distribution of biogenic and authigenic calcite suggests that the source of calcium carbonate for the cement is local, and that the process generally involves merely solution and reprecipitation without much circulation of interstitial fluid.

Oozes, chalks, and limestones that can be reasonably supposed to have been deposited in comparable environments allow a study of the different steps of lithification.

The oozes consist dominantly of calcite tests of microfossils (foraminifera and/or nannoplankton). Compaction by overburden is responsible for some induration of the oozes, which tend to lose their plasticity.
The first solution and recrystallization processes produce chalk, in which the most fragile tests (foraminifera) are dissolved, and coccoliths are often broken and partially recrystallized. Small calcite grains are also observed in the chalks; they can either be authigenic or the result of coccolith shield fragmentation (see Figure $25 \mathrm{C}$ ). It is possible that some isolated fragments have served as nuclei for the growth of larger crystals in further stages of lithification.

In the limestones, cementation by micritic calcite seems to be dominant, and is probably the result of pressure-solution processes. These processes involve calcite solution at grain contacts, due to high strains generated by compaction, and reprecipitation of calcite in the unstrained pore-spaces (Bathurst, 1968, 1969). The frequent observation of solution effects in the peripheral (distal) parts of coccolith shields and recrystallization in the central areas of the shields favor this explanation (Figure 25). There are apparently critical temperature and pressure values at which this process can operate, as the boundary between unlithified and lithified sediments is usually sharp in homogeneous carbonate sediments. In the Cat Gap area, this "lithification front" seems to play a dominant role in the production of acoustic reflectors (Ewing and Hollister, this volume).

\section{EVOLUTION OF THE SEDIMENTARY ENVIRONMENTS IN THE BASIN: SUMMARY}

The correlation between several sites show that most of lithological facies encountered here have a basin-wide extention and they characterize different phases in the sedimentary evolution of the North American basin (see Figure 25). These different phases may be defined as follows:

1. Formation of the basaltic basement (Middle to Late Jurassic)

2. Deposition of the basal carbonate sediments (Late Jurassic to Early Cretaceous)

3. Early Cretaceous stagnation.

4. Late Cretaceous-early Tertiary volcanic phase.

5. Massive accumulation of the Tertiary hemipelagic sediments.

6. Pleistocene major terrigenous output.

7. Post-glacial thin pelagic cover.

Apart from the last phase, which is recorded by only relatively thin sediments, the boundaries between these sedimentary stages listed above correspond to distinct reflectors on the seismic profiles (Figure 26). The basement is usually easily defined on the profiles; the top of the basal limestones corresponds to Horizon $\beta$; Horizons $\mathrm{A}^{*}$ and $\mathrm{A}$ probably mark the lower and upper 

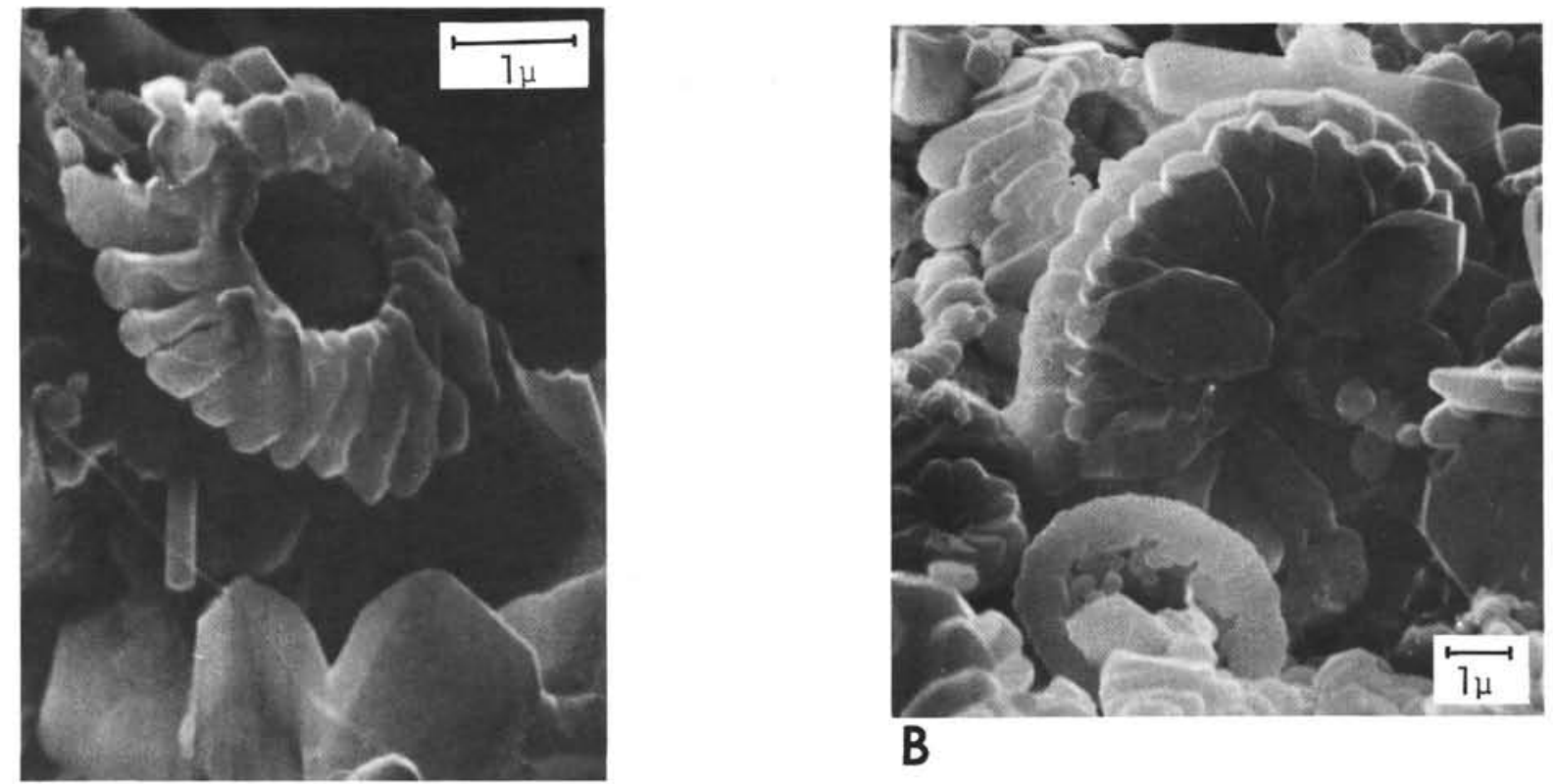

A

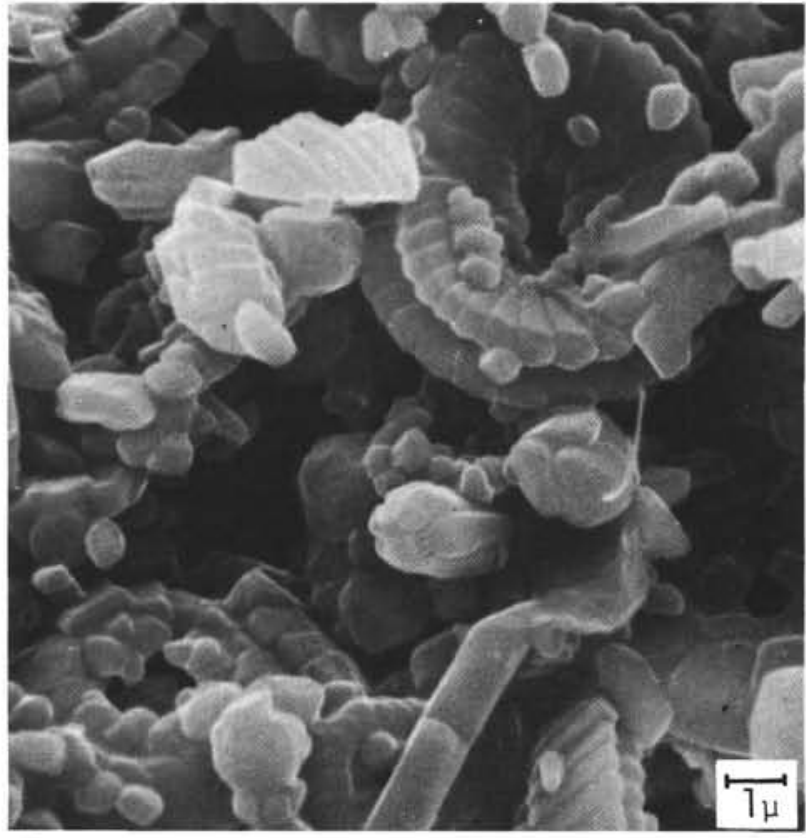

C

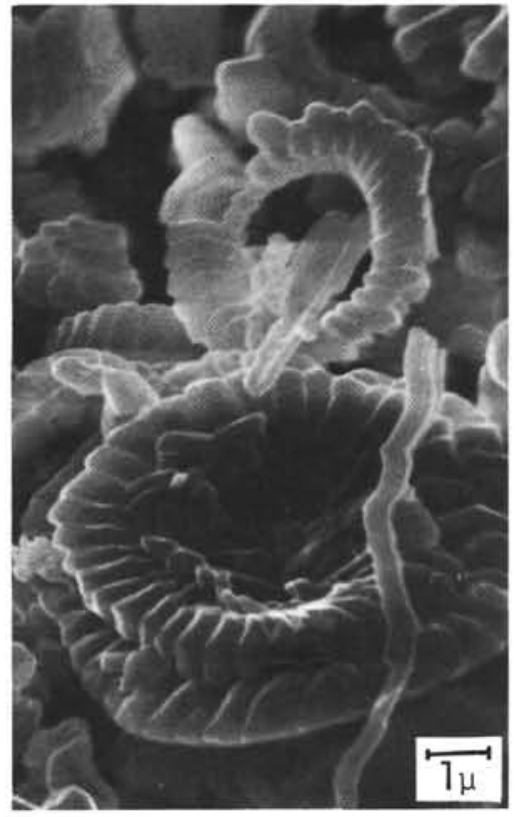

D

Figure 25. Lithification of carbonate sediments $=$ dissolution and recrystallization of calcite (Scanning electron micrographs).

A. Early cretaceous limestone $(105-32-2,87$ to $95 \mathrm{~cm})$; dissolution of an isolated coccolith shield. Note the etching of the distal elements. Note also the presence of large crystals of calcite in the lower part of the picture. $B$ and D. Late Jurassic limestone $(99 A-11-2,50$ to $56 \mathrm{~cm}$ ); dissolution of isolated coccolith shields (B, upper and lower left; $D$, upper part) and recrystallization of the central and proximal areas of a coccolith ( $B$, center and $D$, lower part).

C. Late Cretaceous chalk (98-14-1, 72 to $74 \mathrm{~cm})$; incipient lithification. Note the abundance of small calcite crystals. Some recrystallization is visible in the coccolith at lower left corner of the picture. 
limits, respectively, of the volcanic-rich deep sea clays; most of the terrigenous Pleistocene layers are highly stratified and give strong, closely-spaced reflections on the records.

It is then possible to make acceptable correlations over large areas of the basin even relatively far from the control provided by the drilling sites.

\section{First phase: Basement}

The basement consists of basaltic flows which, in this part of the Atlantic basin, are believed to be the result of Middle to Late Jurassic extrusions. In the northern area (Site 105), the nature of the basalt as well as the basement topography appear very similar to that of the present mid-Atlantic Ridge system. The resulting topography is relatively rough and shows highs and lows having an amplitude of several hundreds of meters and a wave length of a few kilometers.

In the Cat Gap area the picture is somewhat different and the basement does not appear as a typical oceanic ridge feature. It is topographically generally smooth, with only some isolated peaks and ridges; this may be a consequence of different volcanic processes during the first stages of Atlantic rifting.

\section{Second phase: Basal Carbonate deposits (Middle-Late Jurassic to Neocomian)}

\section{Cat Gap Area}

The first sediments deposited on the basalt in the southern part of the studied area reflect a calm environment in a water depth difficult to evaluate precisely, but definitely well above the carbonate compensation depth although still in the bathyal realm. Very weak currents were able to keep the bottom waters well oxygenated, as is evidenced by the abundant burrows of benthic organisms. Only very rarely was terrigenous material delivered to this relatively flat area.

Above these first layers, the limestones contain much more clay (mainly montmorillonite) and show more evidence of post-depositional movement (clasts and flow structures). This would indicate the presence of topographic relief and possibly increasing tectonic and volcanic activity in the area.

These limestones are overlain by Tithonian to Neocomian homogeneous carbonate oozes which were probably deposited in a calm and well-oxygenated environment into which some rare detrital carbonate grains were transported from the nearby Bahamian area.

\section{Lower Continental Rise and Blake-Bahama Outer Ridge System}

Because the basement topography is relatively rough, the earliest sediments of the northern area (OxfordianKimmeridgian) comprise two facies. White pelagic carbonate oozes, with a slow rate of accumulation and reflecting a well-oxygenated environment, were deposited on basement highs. These sediments will be referred to as "summital" in the following discussion. They contain abundant calcareous microfossils and some Radiolaria and are almost devoid of any terrigenous detritus. In the inter-hill depressions very clayey, red, hematite-rich limestones, reflecting "basinal" conditions, accumulated at a relatively high rate. Due to the displacement of sediments from the tops of the hills into the depressions by turbidity currents and slumping, the "basinal" sediments show an important incorporation of "summital" material in the form of white and pink clasts. The net result of these displacements and of the different rates of accumulation of the "summital" and "basinal" facies was the rapid filling of the depressions. This type of sedimentation prevailed through the Oxfordian, Kimmeridgian, Tithonian, and part of the Neocomian.

The downslope transport of sediment seems to have reached a maximum in the Tithonian, where most of the massive slumps are observed. Slumping might have been triggered by tectonic activity accompanying the gradual subsidence of the whole area; the disappearance of volcanic clasts shows an increasing distance from the active rift zone.

During the final stage of depression filling, the facies changed to a cyclic sedimentation where well-oxygenated conditions (white limestones with burrowing) alternate with more and more abundant stagnant periods (laminated soft clayey limestones). These alternations may have been caused by some periodic slow bottom-current circulation.

The stagnant conditions become predominant in the Hauterivian-Barremian where the white limestones disappear and give way to a facies transitional to the Aptian-Cenomanian black clays.

The general subsidence of the area has been continuous and, at the end of this second phase, the facies encountered in the basin are considered deep bathyal and probably not yet abyssal.

\section{Third Phase: Early Cretaceous Stagnation}

Although gradational at Site 105, the facies change is relatively sharp and the transition zone is short enough to produce a sometimes weak but distinct reflector (Horizon $\beta$ ) on the seismic profiles obtained in most of the western part of the basin. The deposition of the 


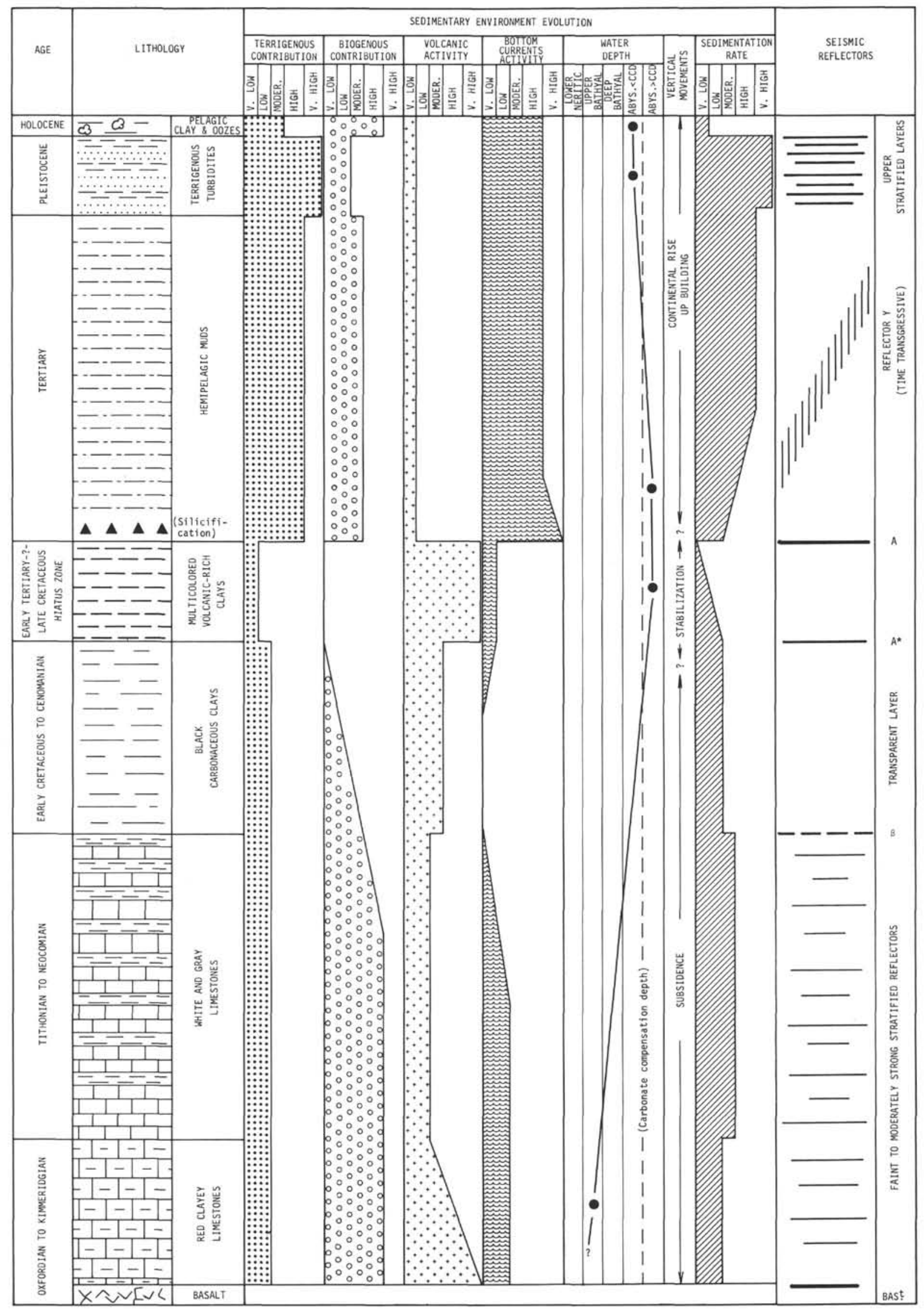

Figure 26. Evolution of the sedimentary environment in the North American basin since the Late Jurassic (summary). 

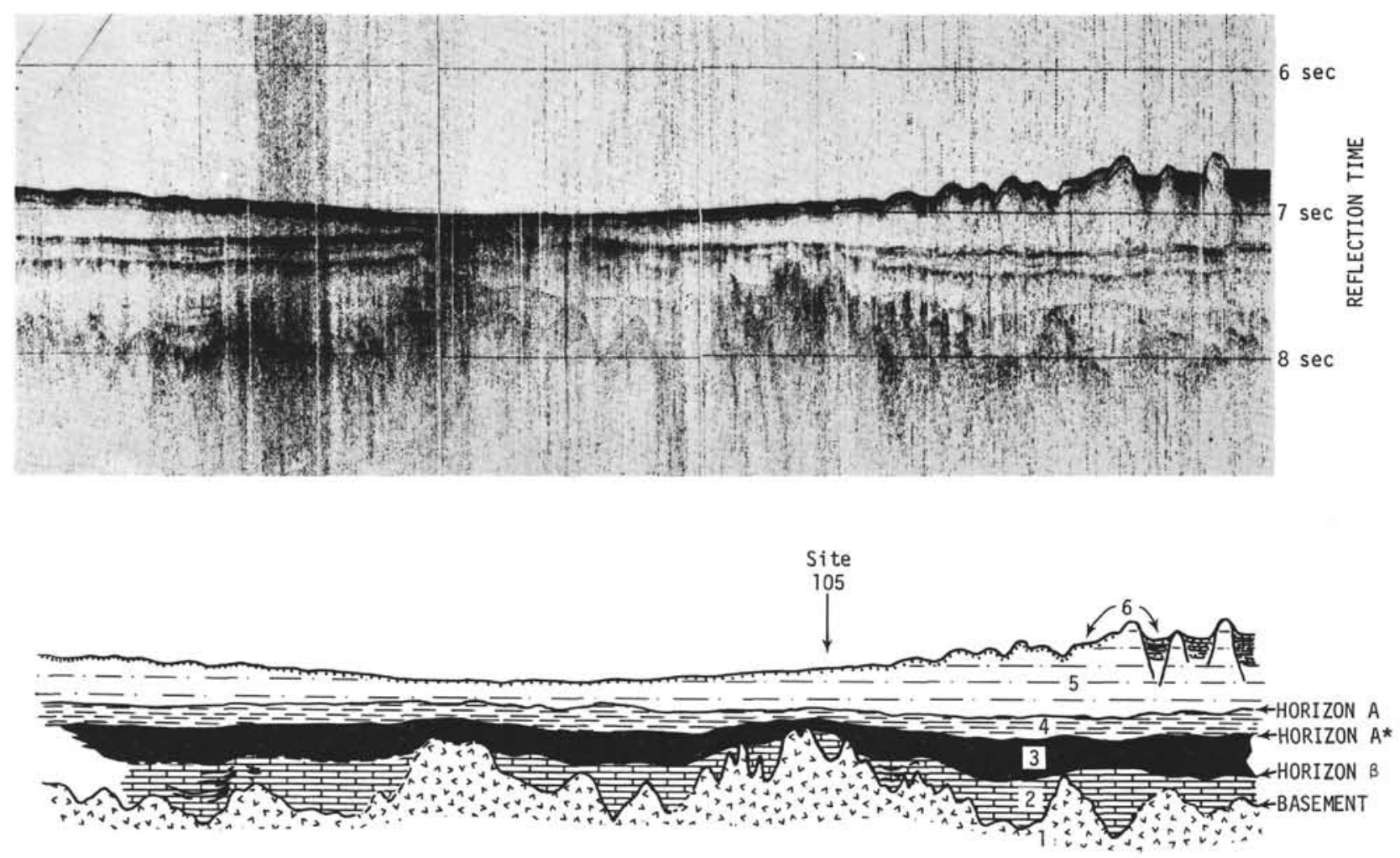

SEDIMENTS SECTION IN THE VICINITY OF SITE 105

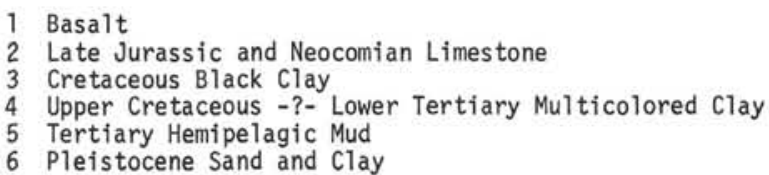

Figure 27. Sediment section in the vicinity of Site 105.

highly carbonaceous clays began during the Barremian in the whole North American basin (Sites 101 and 105) and appears to have been more or less synchronous and well developed in the Aptian-Albian times in most of the North Atlantic (Leg 14, Sites 135, 137, 138 and 144).

Stagnation was probably not continuous during the whole interval of black clay deposition, for, in the upper part, many cycles, comparable to those observed in the Neocomian limestones were seen; these attest to the presence of occasional aerobic conditions, probably due to intermittent slow bottom water circulation which allowed the survival of some benthonic organisms. However, statistically, the stagnant conditions prevailed during the whole Barremian to Early Cenomanian interval, producing an euxinic environment and the accumulation of large amounts of organic matter.

The abundance of zeolites and montmorillonite suggests continuous volcanic activity in the basin. The contribution of detrital terrigenous material to the basin remained relatively small during the Early Cretaceous. The presence of some deep-sea "red clay" at the top of the euxinic interval indicates deep-water conditions at the close of this phase of deposition.

\section{Fourth Phase: Late Cretaceous -?- Early Tertiary? Volcanic Phase and Hiatus}

A major lithological break marks the top of the previous phase of sedimentation. This sharp break appears to be recorded on the seismic profiles as Horizon A*. This horizon can be observed just under Horizon A in a wide area, extending from the area of Site 105 to the north of Site 101.

The interval between Horizons $\mathrm{A}$ and $\mathrm{A}^{*}$ shows an exceptionally low sedimentation rate, and it is probable that some erosion occurred since the entire Late Cretaceous, Paleocene and Early Eocene section is condensed to little more than 50 meters. 
This condensation is mainly a result of the very small proportion of terrigenous material, and the absence of calcareous and siliceous microfossils. The major components of the sediments of this interval are of volcanic origin and most of the striking metal-enrichment of these layers is believed to be the result of direct precipitation from concentrated solutions generated by major volcanic activity in the basin, following processes comparable to those observed presently at the bottom of the Red Sea. Such areally extensive deposits require a calm environment in the basin, and if erosion by strong currents has to be invoked to explain the major shortening of this interval, it is difficult to observe any direct evidence of current erosion in the sediments themselves. Furthermore, since this interval is unfossiliferous, it is difficult to know precisely directly the age of the initiation of strong current circulation which ended the phase of deposition of dominantly volcanogenic sediments and initiated the nondepositional or erosional phase in the basin. The occurrence of abundant volcanic material recorded in Upper Cretaceous sediments from various parts of the Atlantic Ocean (Legs 1,2 and 14) suggests that the major volcanic phase observed at Site 105 took place during that time. The hiatus could then be placed near the top of the volcanogenic section and would correlate with the shortened sediment section between the latest Cretaceous and middle Eocene observed at many sites in both the Atlantic and Pacific Oceans. In the Cat Gap area, evidence of significant current circulation can be observed in sediments as old as Cenomanian (Leg 1) and, correspondingly, some evidence of the initiation of slow circulation is present in sediments from the same age at Site 105. The circulation could have reached a maximum in the latest Cretaceous and early Tertiary. It is recorded by major erosion in the south (Site 101) and lesser erosion to nondeposition in the area of Site 105.

The widespread volcanic activity is probably related to a major phase in the tectonic history of the North Atlantic Ocean. Pitman and Talwani (in press) have shown that a significant change in the pattern of the fracture zones occurred in the Late Cretaceous. This change probably accounts for an important shift in the directions of motion of the American and African plates. It is possible that this readjustment in plate motion produced great stresses and tensional shear along the fracture zones, resulting in increased volcanic activity all over the basin and especially in the Bermuda Rise and New England seamount areas.

\section{5th Phase: Massive Accumulation of Tertiary Sediments and the Building of the Continental Rise}

The middle Eocene marks the beginning of a completely new type of sedimentary regime that has lasted, in the continental rise area, during the entire Tertiary. This important change is characterized by abundant terrigenous detritus in the sediments. It is probable that a vigorous bottom-water circulation, in the form of an ancestral Western Boundary Current, has been responsible for the delivery and accumulation of this material along the continental margin over the relatively flat Horizon A. Horizon A itself was not actually sampled during Leg 11 and it cannot be definitely established whether or not this reflector is a result of the presence of chert. In any case, it seems to be closely associated with the major hiatus, or condensed sequence, observed at the base of the Tertiary. In the Cat Gap area the reflector appears to be directly related to an erosional surface (Site 101). In the deepest part of the area the currents have remained strong enough until the present to prevent any further sedimentation.

The most important increase in the rate of accumulation of the sediments occurred in the lower continental rise region during the Middle Miocene and may have occurred somewhat earlier in the Blake-Bahama Outer Ridge area. Most of these topographic features were built between the Oligocene and Pleistocene (Ewing and Hollister, this volume). The distribution of siliceous and calcareous fossils in these sediments seems to indicate that the building of these topographic features has brought the sea floor progressively above the carbonate compensation depth. At Site 106, the Eocene sediments are noncalcareous, indicating deposition below the carbonate compensation depth; whereas, at Site 108 on the continental slope the Eocene is characterized by equal amounts of calcareous and siliceous microfossils. However, commencing with the middle Miocene at Site 106, there is a gradual increase in carbonate content toward the top of the section. This suggests that the progressive building of the continental rise brought the sea floor above the carbonate compensation depth during the Miocene.

\section{6th Phase: The Pleistocene Major Terrigenous Output}

In the western North Atlantic, the only massive accumulation of coarse terrigenous sediments began with the Pleistocene. Most of these deposits have been brought down from the shelf area to the deeper parts of the basin by turbidity currents and have accumulated in the abyssal plains as well as in depressions on the lower continental rise (Site 106). Part of this material has been carried along the continental rise by contour currents and has been widely distributed on the rise and the Blake-Bahama Outer Ridge system. It appears that most of the present physiography of the western North Atlantic has resulted from Tertiary and Quaternary terrigenous accumulation.

\section{7th Phase: The Recent Post-Glacial Sedimentation}

Since the rise of sea level to its present position, terrigenous sedimentation in the basin has been relatively 
minor and is mainly represented by fine-grained deposits, while some coarse material is still occasionally carried down from the shelf through submarine canyons by turbidity currents.

The overall rate of terrigenous sedimentation for this Recent epoch marks a very important decrease after the Pleistocene thick accumulations of the abyssal plains and the sedimentation is dominantly pelagic. However, it should be pointed out that this phase of dominantly pelagic deposition has probably occurred repeatedly during the glacial Pleistocene, as a result of glacio-eustatic rises of sea level.

\section{ACKNOWLEDGEMENTS}

The writers are indebted to the entire Leg 11 scientific and technical party for their enthusiastic cooperation aborad the Glomar Challenger. We are also most grateful to J. I. Ewing (Lamont-Doherty Geological Observatory), Daniel Bernoulli (University of Basel, Switzerland) and Hanspeter Luterbacher (ESSO-EPR, France) for providing helpful comments and insights during our many discussions.

We thank Virginia Peters (Woods Hole Oceanographic Institution) and Daniel Bernoulli for providing scanning electron micrographs, and Marie-Claude Sichere (University of Paris, France) and Georges Kulbicki (Societe Nationale des Petroles d'Aquitaine, France) for chemical analyses.

The assistance given by F. T. Manheim (U.S. Geological Survey), D. A. Ross and J. R. Heirtzler (Woods Hole Oceanographic Institution), and Ansis Kaneps (D.S.D.P., Scripps Institution of Oceanography) leading to improvement of the manuscript was greatly appreciated.

\section{REFERENCES}

Bathurst, R. G. C., 1958. Diagenetic fabrics in some British Dinantian limestones. Liverpool Manchester Geol. J. 2, 11 .

Bathurst, R. G. C., 1959. Diagenesis in Mississipian calcilutites and pseudobreccias. J. Sediment. Petrol. 29,365 .

Bischoff, J. L., 1969. Red Sea geothermal brine deposits - their mineralogy, chemistry and genesis. In Hot Brines and Recent Heavy Metal Deposits in the Red Sea. E. T. Degens and D. A. Ross (Eds.). New York (Springer-Verlag, Inc.), 368.

Blow, W. H., 1969. Late Middle Eocene to Recent planktonic biostratigraphy. In Proc. First Intern. Conf. Plank. Microfossils. 1, 109.

Bonatti, E., 1967. Mechanisms of deep-sea colvanism in the South Pacific. In Researches in Geochemistry. New York (J. Wiley and Sons, Inc.), 2, 453.
Bonatti, E. and Arrhenius, G. O., 1970. Acidic rocks on the Pacific ocean floor. In The Sea. A. E. Maxwell (Ed.). New York (Interscience), 4, 445.

Bonatti, E. and Joensuu, O., 1968. Palygorskite from Atlantic deep-sea sediments. Am. Mineralogist. 53, 975.

Bostrom, K. and Peterson, M. N. A., 1966. Precipitates from hydrothermal exhalations on the East Pacific Rise. Econ, Geol. 61, 1258.

Bostrom, K. and Peterson, M. N. A., 1969. The origin of aluminum-poor ferromanganoan sediments in areas of high heat-flow on the East Pacific Rise. Marine Geol. 7, 427.

Bostrom, K., Peterson, M. N. A., Joensuu, O. and Fischer, D. E., 1969. Aluminum poor ferromanganoan sediments on active oceanic ridges. $J$. Geophys. Res. 74, 3261.

Chamley, H. and Millot, G., 1970. Séquence sédimentaire à Attapulgite dans une carotte profonde prélevée en Mer Ionienne (Méditerranée orientale). $C$. R. Acad. Sci. Paris. 270, Serie D, 1084.

Chilingar, G. V., Bissell, H. J. and Wolf, K. H., 1967. Diagenesis of carbonate rocks. In Diagenesis in Sediments. G. Larsen and G. V. Chilingar (Eds.). Amsterdam (Elsevier), 179.

Cloud, P. E., 1960. Gas as a sedimentary and diagenetic agent, Am. J. Science. 258-A, 35.

Degens, E. T. and Ross, D. A. (Eds.), 1969. Hot Brines and Recent Heavy Metal Deposits in the Red Sea. New York (Springer-Verlag), 599.

Emery, K. O., Uchupi, E., Phillips, J. D., Bowin, C. O., Bunce. E. T. and Knott, S. T., 1970. Continental rise off eastern North America. Bull. Am. Assoc. Petrol. Geol. 54 (1), 44.

Ericson, D. B., Ewing, M., Wollin, G. and Heezen, B. C., 1961. Atlantic deep sea sediment cores. Bull. Geol. Soc. Am. 72, 193.

Ewing, J., Windisch, C. C. and Ewing, M., 1970. Correlation of Horizon A with JOIDES bore-hole results. J. Geophys, Res. 75 (29), 5645.

Ewing, M., Worzel, J. L., Beall, A. O., Berggren, W. A., Bukry, D., Burk, C. A., Fischer, A. G. and Pessagno, Jr., E. A., 1969. Initial Reports of the Deep Sea Drilling Project, Volume I. Washington (U.S. Government Printing Office). 672.

Fairbridge, R. W., 1967. Phases of diagenesis and authigenesis. In Diagenesis in Sediments. G. Larsen and G. V. Chilingar (Eds.). Amsterdam (Elsevier), 19.

Habib, D., 1970. Middle Cretaceous palynomorphs assemblages from clays near the Horizon Beta deepsea outcrop. Micropaleontology. 16 (3), 345.

Hathaway, J. C., in press. Regional clay mineral facies in the estuaries and continental margin of the United States east coast. In Environmental framework of coastal plain estuaries. B. W. Nelson (Ed). Geol. Soc. Am. Memoir 133. 
Hathaway, J. C., McFarlin, P. F. and Ross, D. A., 1970. Mineralogy and origin of sediments from drill-holes on the Continental margin off Florida. U. S. Geol. Surv. Profess. Paper 581-E, 26 pp.

Hathaway, J. C. and Sachs, P. L., 1965. Sepiolite and clinoptilolite from the mid-Atlantic Ridge. $\mathrm{Am}$. Mineralogist. 50, 852 .

Hayes, D. E., Pimm, A. C., Benson, W. E., Berger, W. H., von Rad, U., Supko, P. R., Beckmann, J. P., Roth, P. H. and Musich, L. F., 1971. Deep Sea Drilling Project, Leg 14. Geotimes. 16, 2.

Hays, J. D., Cook. H., Cook. F., Fuller, J., Jenkins, G., Goll, R., Milow, D. and Orr, W., 1970. Deep Sea Drilling Project: Leg 9. Geotimes. 15, 4.

Heezen, B. C., Hollister, C. D. and Ruddiman, W. F., 1966. Shaping of the continental rise by deep geostrophic contour currents. Science. 152 (3721), 502.

Heezen, B. C., Nesteroff, W. D., Oberlin, A. and Sabatier, M. G., 1965. Découverte d'attapulgite dans les sédiments profonds du Golfe d'Aden et de la Mer Rouge. Comp. Rend. Som. Soc. Geol. de France, Paris. 260, 5819.

Hendricks, R. L., Reisbick, F. B., Mahaffey, E. J., Roberts, D. B. and Peterson, M. N. A., 1969. Chemical composition of sediments and interstitial brines from the Atlantis II, Discovery and Chain Deeps. In Hot Brines and Recent Heavy Metal Deposits in the Red Sea. E. T. Degens and D. A. Ross (Eds.), New York (Springer-Verlag), 407.

Hollister, C. D., 1967. Sediment distribution and deep circulation in the western North Atlantic. (Unpubl. ph.D. dissert. Columbia Univ.), 467 pp.

Kraft, J. C. and Maisano, M. D., 1968. A geologic cross section of Delaware. Publ. Univ. Delaware Water Resources Center. Newark, Delaware.

Laughton, A. S., Berggren, W. A., Benson, R., Davies, T. A., Franz, U., Musich, L. F., Perch-Nielsen, K., Ruffman, A., van Hinte, J. E. and Whitmarsh, R. B., 1970. Deep Sea Drilling Project, Leg 12. Geotimes. $15(9), 10$.
MacDougall, D., 1971. Deep Sea Drilling = Age and composition of an Atlantic basaltic intrusion. Science. 171, 1244.

Moore, T. C. and Heath, G. R., 1967. Abyssal hills in the central equatorial $\mathrm{Pacific}=$ detailed structure of the sea-floor and subbottom reflectors. Marine Geol. 5,161 .

Murray, J. and Renard, A. F., 1891. Deep sea deposits Rept. Sci. Results of the Voyage of H. M. S. Challenger. Sec. 3. 1, 525.

Peterson, M. N. A., Edgar, N. T., von der Borch, C., Cita, M. B., Gartner, S., Goll, R. and Nigrini, C., 1970. Initial Reports of the Deep Sea Drilling Project, Volume II. Washington (U. S. Government Printing Office) $501 \mathrm{pp}$.

Pimm, A. C., Garrison, R. E. and Boyce, R. E., 1971. Sedimentology synthesis: lithology, chemistry and physical properties of sediments in the northwestern Pacific Ocean. In Fischer, A. G. et al., 1971. Initial Reports of the Deep Sea Drilling Project, Volume VI. Washington (U.. S. Government Printing Office) 1311.

Pitman, W. and Talwani, M., in press. Sea-floor spreading in the North Atlantic. Bull. Geol. Soc. Am.

Siever, R. and Kastner, M., 1967. Mineralogy and petrology of some mid-Atlantic Ridge sediments. $J$. Marine Res. 25, 263.

von der Borch, C. C., Nesteroff, W. D. and Galehouse, J. S., 1971. Iron rich sediments cored during Leg 8 of the Deep Sea Drilling Project. In Tracey, J. et al., Initial Reports of the Deep Seal Drilling Project, Volume VIII. Washington (U. S. Government Printing Office) 541 .

von der Borch C. C., and Rex, R. W., 1970. Amor phous iron oxide precipitates in sediments cored during Leg 5, Deep Sea Drilling Project. In McManus, D. A., et al. 1970. Initial Reports of the Deep Sea Drilling Project, Volume V. Washington (U. S. Government Printing Office) 541.

Windisch, C. C., Leyden, J. L., Worzel, J. L., Saito, T. and Ewing, J., 1968. Investigation of Horizon $\beta$. Science. 162 (3861), 1473. 